UNIVERSIDADE DE SÃO PAULO

INSTITUTO DE ENERGIA E AMBIENTE

NÁDIA COSTA PONTES

A Transposição do Rio São Francisco como potencial medida de adaptação às mudanças climáticas

São Paulo

2018 
NÁDIA COSTA PONTES

\section{A Transposição do Rio São Francisco como potencial medida de adaptação às mudanças climáticas}

\section{Versão Original}

Dissertação apresentada ao Instituto de Energia e Ambiente da Universidade de São Paulo para obtenção do título de Mestre em Ciência Ambiental.

Orientador: Paulo Eduardo Artaxo Netto

São Paulo 


\begin{abstract}
AUTORIZO A REPRODUÇÃO E DIVULGAÇÃO TOTAL OU PARCIAL DESTE TRABALHO, POR QUALQUER MEIO CONVENCIONAL OU ELETRÔNICO, PARA FINS DE ESTUDO E PESQUISA, DESDE QUE CITADA A FONTE.
\end{abstract}

\author{
FICHA CATALOGRÁFICA
}

Pontes, Nádia Costa.

A transposição do Rio São Francisco como potencial medida de adaptação ás mudanças climáticas. / Nádia Costa Pontes; orientador: Paulo Eduardo Artaxo Netto. - São Paulo, 2018.

114 f.: il; $30 \mathrm{~cm}$.

Dissertação (Mestrado em Ciência Ambiental) - Programa de PósGraduação em Ciência Ambiental - Instituto de Energia e Ambiente da Universidade de São Paulo.

1. Mudança climática. 2. Recursos hídricos. 3. Governança. 4. Obras de desvio de cursos d'água - Rio São Francisco. I. Título. 
Nome: PONTES, Nádia Costa

Título: A Transposição do Rio São Francisco como potencial medida de adaptação às mudanças climáticas

Dissertação apresentada ao Instituto de Energia e Ambiente da Universidade de São Paulo para obtenção do título de Mestre em Ciência Ambiental.

Aprovado em:

Banca Examinadora

Prof. Dr.

Instituição:

Julgamento:

Prof. Dr.

Instituição:

Julgamento:

Prof. Dr.

Instituição:

Julgamento: 


\section{AGRADECIMENTOS}

Muitas descobertas e reencontros marcaram essa jornada de estudos. A volta para casa depois de cinco anos na Alemanha, o retorno para a universidade mais de uma década após o término da graduação, o regresso às origens de parte da minha família. Na década de 1940, meus avós deixaram a Paraíba, fugiram da pobreza, migraram para São Paulo, onde meu pai nasceu. Também do semiárido partiram os pais da minha mãe para a periferia de Belo Horizonte. Minha mãe, na juventude, foi atrás do sonho de viver em São Paulo, onde enfrentou todas as dificuldades com muita coragem e determinação.

Sou fruto dessas migrações. Agora volto ao território de onde saíram meus avós com o olhar de pesquisadora para investigar como as mudanças climáticas, ameaça certamente desconhecida por minha família simples que abandonou o semiárido, podem forçar mais pessoas a fugir para sobreviver. Agradeço a Deus, aos meus avós e aos meus pais, que sempre me incentivaram a estudar e fizeram inúmeros sacrifícios para que eu chegasse até aqui. Agradeço ao meu marido e companheiro de vida, Diego, pelo apoio incondicional, pelas incontáveis leituras que fez e opinou, pela paciência e compreensão nas semanas em que me ausentei para fazer as pesquisas de campo, pelo amor e história que compartilhamos.

Agradeço imensamente a orientação de Paulo Artaxo, grande pesquisador que representa brilhantemente a ciência brasileira na comunidade internacional. Obrigada, professor Paulo, por sempre ter me atendido com atenção e bom humor, por todas as observações feitas ao longo dessa jornada, pelas trocas interdisciplinares. Foram anos intensos de aprendizado! Gratidão aos meus amigos amados, Sabine, Mário, Lívia, Ricardo e Sérgio, que me acompanharam, ofereceram pouso, café, jantar, ouviram minhas angústias. Obrigada, Bine, por todos os conselhos e ajuda, desde a fase em que escrevia o projeto.

Obrigada, Ericksson, por ter me guiado durante as visitas de campo, por ter acreditado na minha pesquisa. Agradeço também ao amigo Jaime pela gentileza e ajuda incomensurável. Agradeço ainda todos os colegas das disciplinas que fiz, principalmente a Ligia e Pedro, que me auxiliaram muito no universo da engenharia, assim como professor Arisvaldo.

A todas as pessoas que encontrei, entrevistei e fotografei nas visitas de campo, que aguardam a chegada da tão esperada água do São Francisco: obrigada pela acolhida e confiança. Vocês terão o meu respeito eternamente. 
"Governo, coisa distante e perfeita, não podia errar." Graciliano Ramos, Vidas Secas 


\section{RESUMO}

A região Nordeste, primeira a ser ocupada após a chegada dos portugueses no Brasil no século XVI, possui $53 \%$ do seu território sob regime do clima semiárido. Nesse espaço, onde vivem 12 milhões de pessoas, as crises causadas por escassez de água, apontadas como barreiras ao desenvolvimento, são conhecidas há mais de um século, causaram perdas agrícolas, migrações e mortes. A região, de conhecida variabilidade climática, é ainda uma das mais vulneráveis do globo às mudanças climáticas. Até o fim desse século, previsões indicam que a temperatura pode subir $4^{\circ} \mathrm{C}$ em relação à era pré-industrial, com forte impacto sobre os recursos hídricos e desertificação. Diante desse cenário, medidas que oferecem às populações locais condições de se adaptarem se fazem urgentes. Proposto há mais de um século como solução dos problemas trazidos pela escassez de água no semiárido, a transposição do rio São Francisco passou a ser implantada a partir de 2007 sob nome oficial de Projeto de Integração do rio São Francisco com as Bacias Hidrográficas do Nordeste Setentrional (PISF). Trata-se da maior obra de infraestrutura hídrica do país, projetada para transferir $26,4 \mathrm{~m}^{3} / \mathrm{s}$ por dois eixos principais, Norte e Leste, o volume transportado pelos canais é destinado principalmente ao consumo humano e dessedentação animal. Esta dissertação tem o objetivo de analisar o Eixo Leste do PISF como potencial medida de adaptação às mudanças climáticas. A estratégia de investigação aplicada nesse trabalho interdisciplinar se enquadra na pesquisa qualitativa, apoia-se em documentos, imagens, entrevistas não estruturadas e visitas de campo. A pesquisa conclui que a distribuição de água feita pelo Eixo Leste do PISF não contribui para que as populações mais vulneráveis do semiárido se adaptem às mudanças climáticas, mas que o projeto tem potencial para se converter em tal medida.

Palavras-chave: adaptação às mudanças climáticas, transposição do rio São Francisco, Nordeste, semiárido, recursos hídricos, governança, PISF 


\begin{abstract}
The Brazilian Northeast region, the first to be occupied after the arrival of the Portuguese in the 16 th century, has $53 \%$ of its territory under a semi-arid climate regime. This space is home to 12 million people, it has been hit by crises caused by water shortages, which are understood as barriers to development. Known by its climatic variability, the semiarid portion of the Northeast is one of the world's most vulnerable region to climate change. By the end of this century, predictions indicate that temperature could rise by $4^{\circ} \mathrm{C}$ as compared to the preindustrial time, with a strong impact on water resources and desertification. Given this scenario, it is urgent to discuss measures that offer the local population conditions to adapt. Proposed more than a century ago as a solution to the problems brought about by the water scarcity in the semiarid, the project to divert Brazil's Sao Francisco river began to be implemented in 2007 under the official name of the São Francisco River Integration Project with the Northern Northeast Hydro Basins (PISF). It is the largest water infrastructure project in the country, designed to transfer $26.4 \mathrm{~m}^{3} / \mathrm{s}$ through two main axes, Northern and Eastern. The volume transported by the channels is mainly intended for human and animal consumption. This dissertation aims to analyze the Eastern Axis of the PISF of the Northeast of Brazil as a potential adaptation to climate change measure. The research strategy applied in this interdisciplinary work fits the qualitative research, relies on documents, images, unstructured interviews and field visits. The research concludes that the distribution of water by the Eastern Axis of the PISF does not contribute to the adaptation of most vulnerable populations in the semiarid region, but that PISF has the potential to convert to that such measure.
\end{abstract}

Key words: adaptation to climate change, Sao Francisco River, Northeast, semiarid, water resources, governance, PISF, Sao Francisco transfer project 


\section{LISTA DE FIGURAS}

Figura 1 - Mapa do Projeto de Integração do Rio São Francisco com Bacias do Nordeste Setentrional (PISF)

Figura 2 - Mudança na temperatura anual do ar $\left({ }^{\circ} \mathrm{C}\right.$, a-c); precipitação (mm dia-1, d-f); precipitação-evaporação (mm dia-1, g-h) e umidade relativa do ar $(\%, \mathrm{j}-1)$ derivado do downscaling do modelo HadCM3 usando $40 \mathrm{~km}$ lat-lon do modelo regional Eta. 20

Figura 3 - Total de ganho/perda de água em $\mathrm{km} 3 \mathrm{com}$ dados do sistema GRACE de abril de 2002 a março de 2015. Bacia do São Francisco contornada de branco. 21

Figura 4 - Tendência em TWS (centímetros por ano) obtida com base nas observações do GRACE de abril de 2002 a março de 2016 .22

Figura 5 - Mapa que mostra a delimitação do Semiárido Brasileiro. .28

Figura 6 - Principais mudanças observadas no Nordeste do Brasil nos últimos 60 anos......31

Figura 7 - Região Hidrográfica do rio São Francisco. 50

Figura 8 - Açudes que serão beneficiados pelo PISF 55

Figura 9 - Traçado do Eixo Leste do Projeto de Integração do Rio São Francisco com as Bacias Hidrográficas do Nordeste Setentrional (PISF).

Figura 10 - Visão panorâmica da Barragem de Itaparica, Floresta, Pernambuco .60

Figura 11 - Estação de Bombeamento 1 do Eixo Leste, Pernambuco .60 
Figura 12 - Seção transversal da tomada d'água de uso difuso nos canais do Eixo Leste do PISF.

Figura 13 - Mapa das comunidades atendidas pelo Plano Ambiental 15 ao longo do Eixo Leste do PISF .68

Figura 14 - Baixo nível de água no Reservatório Epitácio Pessoa (Boqueirão), Paraíba, em decorrência do ciclo de seca iniciado em 2012 77

Figura 15 - Tomada d'água seca do Reservatório Epitácio Pessoa, PB, em decorrência do ciclo de seca iniciado em 2012 . 77

Figura 16 - Bomba em operação no reservatório de Campos do PISF para acelerar a chegada de água ao açude Epitácio Pessoa, PB 79

Figura 17 - Comunidade rural Serra Negra, Floresta (PE) e sua proximidade a um dos canais do Eixo Leste do PISF. 83

Figura 18 - Local onde bomba clandestina é instalada para retirada de água do Eixo Leste, com distribuição para comunidade Serra Negra, Floresta (PE)....

Figura 19 - Morador retira água ilegalmente do Eixo Leste do PISF, Custódia (PE) 84

Figura 20 - Retirada ilegal de água do Eixo Leste do PISF para formação de reservatório particular, Custódia (PE)

Figura 21 - Visão panorâmica do açude Barra do Juá, Floresta, PE. .86 


\section{LISTA DE TABELAS}

Tabela 1 - Estados que formam a região Nordeste: dados sobre capital, área e população ....26

Tabela 2 - Evolução do debate conceitual sobre adaptação às mudanças climáticas

Tabela 3 - Principais termos usados na literatura de adaptação às mudanças climáticas...

Tabela 4 - Subdivisão da Bacia Hidrográfica do rio São Francisco .50

Tabela 5 - Sistemas de uso difuso do Eixo Leste do PISF previstos para o município de Floresta (PE)

Tabela 6 - Sistemas de uso difuso do Eixo Leste do PISF previstos para o município de Betânia (PE) 70

Tabela 7 - Sistemas de uso difuso do Eixo Leste do PISF previstos para o município de Custódia (PE).......................................................................

Tabela 8 - Sistemas de uso difuso do Eixo Leste do PISF previstos para o município de

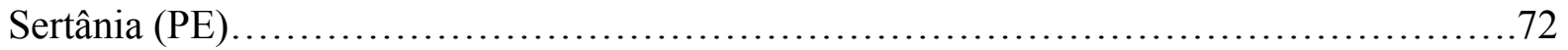

Tabela 9 - Sistemas de uso difuso do Eixo Leste do PISF previstos para o município de

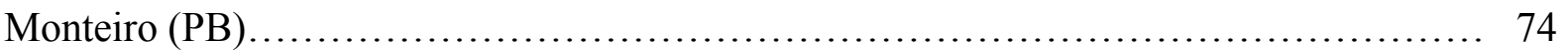




\section{LISTA DE GRÁFICOS}

Gráfico 1 - Queda no nível do reservatório Epitácio Pessoa (PB) de 2008 a 2018........... 76

Gráfico 2 - Queda no nível do reservatório de Barra do Juá, Pernambuco.................. 86

Gráfico 3 - Queda no nível do reservatório de Poço da Cruz, Pernambuco.................. 87

Gráfico 4 - Queda no nível do reservatório de Sobradinho, Bahia....................... 89 


\section{LISTA DE ABREVIATURAS E SIGLAS}

MI

PISF

IPCC

AR5

PBMC

CPTEC

IBGE

ZCIT

VCAS

RAN1

ANA

UNFCCC

ONU

INC

UNEP

UNDP

GEF

UNESCO

CBHSF

DNOCS

Codevasf

Compesa

SARA

AESA

Coopercapri

GRACE

ASA
Ministério de Integração Nacional

Projeto de Integração do Rio São Francisco com Bacias Hidrográficas do

Nordeste Setentrional

Relatório de Impacto Ambiental

Painel Intergovernamental de Mudanças Climáticas

Quinto Relatório de Avaliação

Painel Brasileiro de Mudanças Climáticas

Centro de Previsão do Tempo e Estudos Climáticos

Instituto Brasileiro de Geografia e Estatística

Zona de Convergência Intratropical

Vórtices Ciclônicos do Ar Superior

Relatório de Avaliação Nacional

Agência Nacional de Águas

Convenção-Quadro das Nações Unidas sobre Mudanças Climáticas

Organização das Nações Unidas

Comitê de Negociação Intergovernamental

Programa das Nações Unidas para o Meio Ambiente

Programa das Nações Unidas para o Desenvolvimento

Fundo para o Meio Ambiente

Organização das Nações Unidas para Educação, Ciência e Cultura

Comitê de Bacia Hidrográfica do rio São Francisco

Departamento Nacional de Obras contra as Secas

Companhia de Desenvolvimento dos Vales do São Francisco e do Parnaíba

Companhia Pernambucana de Saneamento

Secretaria de Agricultura de Reforma Agrária de Pernambuco

Agência Executiva de Gestão das Águas da Paraíba

Cooperativa dos Criadores de Caprinos e Ovinos

Gravity Recovery and Climate Experiment

Articulação no Semiárido Brasileiro 


\section{SUMÁRIO}

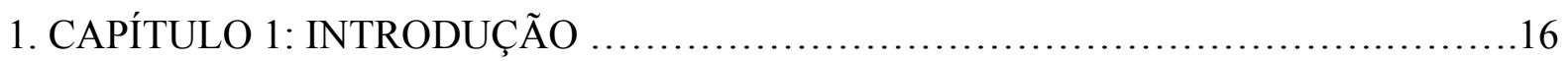

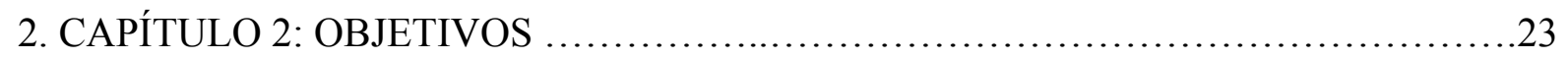

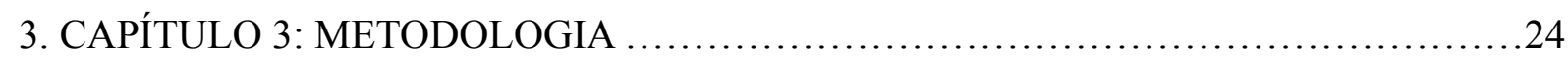

4. CAPÍTULO 4: MUDANÇAS CLIMÁTICAS E O SEMIÁRIDO DO NORDESTE

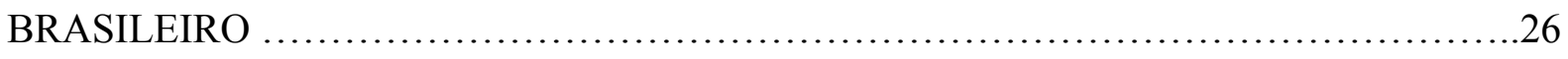

4.1 Caracterização da região semiárida brasileira .................................26

4.2 Mudanças climáticas no semiárido brasileiro .....................................30

4.3 Política Estadual de Enfrentamento às Mudanças Climáticas de Pernambuco.... 35

5. CAPÍTULO 5: MUDANÇAS CLIMÁTICAS E ADAPTAÇÃO ............................37

5.1 Adaptação às Mudanças Climáticas baseada na Vulnerabilidade................. 43

5.2 Adaptação às Mudanças Climáticas no Brasil.......................................45

6. CAPÍTULO 6: RECURSOS HÍDRICOS E TRANSPOSIÇÃO ENTRE BACIAS

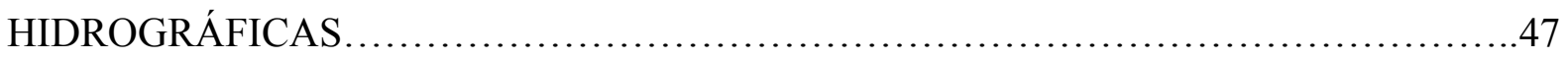

6.1 A Bacia Hidrográfica do rio São Francisco...................................... 48

6.2 Projeto de Integração do rio São Francisco com Bacias Hidrográficas do Nordeste

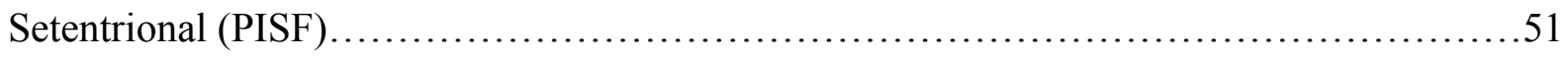

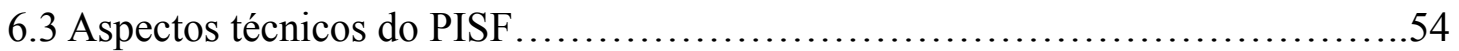

6.4 Distribuição de água pelo Eixo Leste do PISF.................................... 58

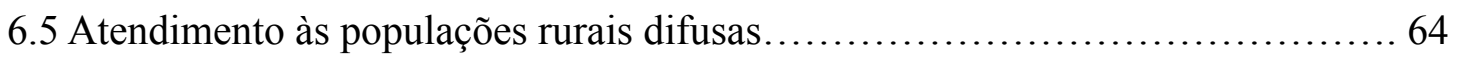

7. CAPÍTULO 7: OBSERVAÇÕES DA PESQUISA DE CAMPO......................... 75

7.1 Operação de emergência para enchimento do açude Epitácio Pessoa, Paraíba... 76

7.2 Comunidades rurais ao longo do Eixo Leste do PISF e a dependência dos caminhões-pipa...... .79 
7.3 Furto de água nos canais do Eixo Leste do PISF

7.4 Água do Eixo Leste do PISF para irrigação................................ 85

7.5 Baixo volume do rio São Francisco e de Sobradinho..........................88

8. CAPÍTULO 8: ANÁLISE INTEGRADA .......................................... 90

8.1 Planejamento do PISF e Mudanças Climáticas............................... 90

8.2 Fornecimento de água no Eixo Leste do PISF e Adaptação às Mudanças

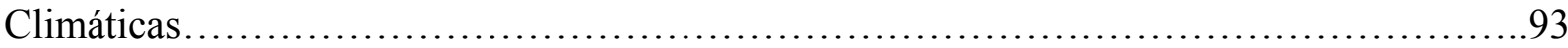

8.3 Gestão do PISF e desafios de governança.................................... 96

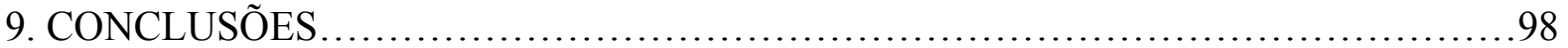

9.1 Recomendações para estudos futuros.................................. 103

REFERÊNCIAS BIBLIOGRÁFICAS............................................ 104

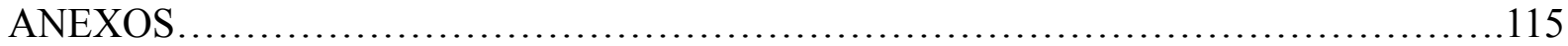




\section{INTRODUÇÃO}

Nesta introdução, os pontos principais que dão base para o desenvolvimento dessa pesquisa serão brevemente expostos com o objetivo de evidenciar a interconexão entre eles. Os temas serão discutidos com profundidade nos capítulos 4, 5 e 6 que formam esse trabalho e permitem a análise integrada, feita no capítulo 7.

A região Nordeste do Brasil apresenta características muito próprias. Ela foi a primeira área ocupada pelos colonizadores portugueses no século XVI. É onde se encontra a porção semiárida do país que, por sua vez, possuiu população rural numerosa que pratica predominantemente a agricultura de subsistência. Ao mesmo tempo, é onde se encontra um dos bolsões de pobreza e miséria do Brasil (LEITE; SOUZA, 2012; SOARES, et al, 2016).

A área do semiárido, com 980.133,079 $\mathrm{km}^{2}$, equivalente a $11,53 \%$ do território brasileiro (MEDEIROS et al, 2012), também é uma das mais vulneráveis às mudanças climáticas. Marcada pela irregularidade de chuvas, com longo e conhecido histórico de secas estudado pela comunidade científica, os moradores do semiárido estão expostos a constantes crises causadas pela escassez de água, que ameaça a sobrevivência na região (MARENGO et al, 2011).

A gestão dos recursos hídricos nessa porção semiárida do país, portanto, sempre foi cercada de desafios. Além das condições climáticas naturais, com temperaturas elevadas, alta taxa de evapotranspiração e solo que favorece a formação de rios intermitentes, o armazenamento de água de forma ineficiente e, muitas vezes, concentrado, acirra os conflitos sociais (MARENGO et al, 2011; MEDEIROS et at., 2011; NOBRE et al, 2011).

Diante desse cenário, soluções que garantam uma fonte de água segura e perene à região e que, por outro lado, possibilitem o seu desenvolvimento, estão em discussão há mais de 100 anos. Dentre as possibilidades discutidas, o desvio para o território do semiárido de parte das águas do rio São Francisco, conhecido como o rio da integração nacional, é considerado desde 1875. A opção é percebida pelos moradores locais como fonte não só de água, mas também de esperança, trazendo uma solução permanente para a escassez recorrente (MINISTÉRIO DA INTEGRAÇÃO NACIONAL, 2004; CBHSF, 2016).

A ideia foi explicitada em diferentes projetos, que embalaram o debate público por várias décadas, ora caindo em esquecimento. Em 2004, o Ministério da Integração Nacional 
(MI) tornou público o projeto que deveria ser executado e finalizado até 2010, entitulado oficialmente de Projeto de Integração do Rio São Francisco com Bacias Hidrográficas do Nordeste Setentrional (PISF), popularmente chamado de transposição do rio São Francisco. No início de 2018, passados mais de oito anos do prazo estabelecido pelo cronograma inicial, as obras do empreendimento seguem em fase de finalização (MINISTÉRIO DA INTEGRAÇÃO NACIONAL, 2004).

Classificado como empreendimento de infraestrutura hídrica, o projeto transporta águas por dois grandes conjuntos de canais, chamados de Eixo Norte e Eixo Leste, pelo semiárido do Nordeste. A figura 1 mostra o percurso dos eixos principais, em azul, e dos ramais paralelos projetados.

Figura 1- Mapa do Projeto de Integração do Rio São Francisco com Bacias do Nordeste Setentrional (PISF)

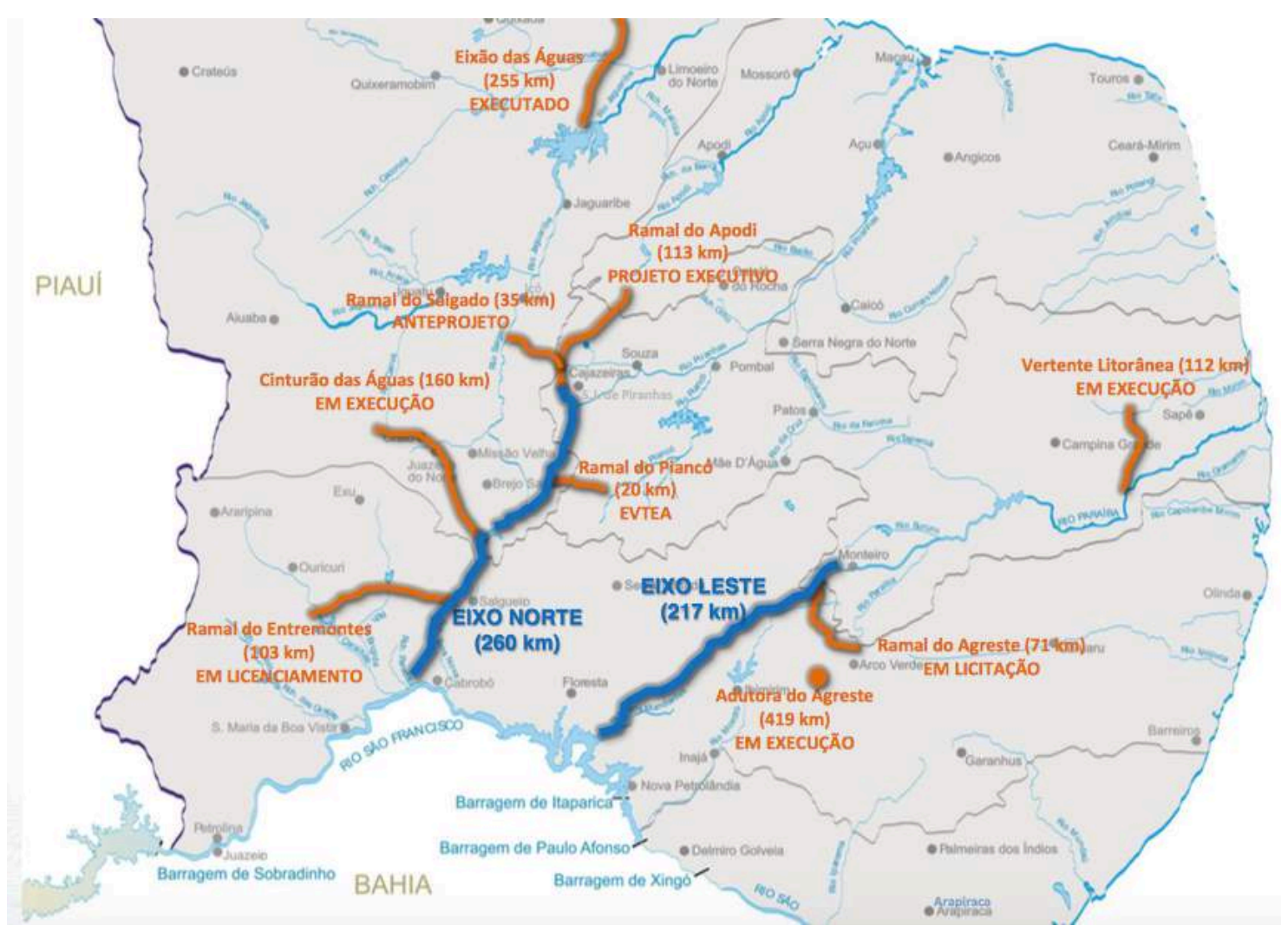

Fonte: Ministério da Integração Nacional, 2017 
O trabalho de engenharia precisou vencer obstáculos do terreno do semiárido, construiu reservatórios, estações de bombeamento, galerias, túneis e sistemas de distribuição de água para uso difuso (MINISTÉRIO DA INTEGRAÇÃO NACIONAL, 2004; CONSÓRCIO TECHNE-PROJETETEC-BRLi, 2012; CONSÓRCIO ECOPLAN-SKILL, 2014).

Dentre os principais objetivos do PISF foram listados a garantia de atendimento às necessidades de abastecimento de municípios do semiárido brasileiro, Agreste Pernambucano e Região Metropolitana de Fortaleza; solução para os problemas trazidos pela escassez de água naquela região, com fornecimento do recurso natural para até 12 milhões de moradores para abastecimento humano; irrigação e dessedentação de animais (MINISTÉRIO DA INTEGRAÇÃO NACIONAL, 2004; CONSÓRCIO TECHNE-PROJETETEC-BRLi, 2012; CONSÓRCIO ECOPLAN-SKILL, 2014).

Desde sua fase inicial de discussão, porém, o empreendimento esteve envolto em polêmicas. Questionado no âmbito jurídico por diversas ações, o projeto recebeu críticas de entidades por ter desconsiderado preceitos do direito ambiental e a busca pelo desenvolvimento ambiental (HENKES, 2014; CBHSF, 2016).

O planejamento da obra não incluiu uma variável importante: os impactos das mudanças climáticas. Ao longo das 129 páginas do Relatório de Impacto Ambiental (RIMA), documento que apresenta um resumo dos estudos técnicos disponíveis no Estudo de Impacto Ambiental (EIA) do PISF, o termo "mudanças climáticas” sequer é citado.

Por outro lado, numerosos estudos, muitos publicados por agências e institutos do governo brasileiro, indicam que as mudanças climáticas estão em curso e deverão trazer impactos em todo o globo. O AR5, quinto e mais recente relatório de avaliação do Painel Intergovernamental de Mudanças Climáticas (IPCC), painel científico composto por 195 países que avalia o conhecimento produzido na área e o sintetiza em forma de relatórios, conclui que a atmosfera e oceanos estão mais quentes, a quantidade de neve e gelo diminuíram e o nível do mar subiu. Muitas dessas mudanças observadas desde a década de 1950 são sem precedentes, nunca tendo sido registradas nas últimas décadas e milênio (IPCC, 2014).

Dentre as mudanças já observadas no Brasil, o relatório do IPCC cita o leve declínio médio das chuvas no Nordeste, região caracterizada por forte variabilidade interanual e decenal. A atribuição da redução da precipitação no Nordeste é difícil exatamente pela alta 
variabilidade climática. As projeções do AR5 (IPCC, 2014), dependendo do cenário de emissões, indicam um aumento de temperatura entre $1,7^{\circ} \mathrm{C}$ e $6,7^{\circ} \mathrm{C}$ até o fim desse século para o Nordeste brasileiro. Quanto ao regime de chuvas, a previsão é que haja uma redução significativa no Nordeste brasileiro, em torno de $22 \%$ de queda.

Projeções climáticas feitas por Marengo e Bernasconi (2015) sugerem aumento de $2^{\circ} \mathrm{C}$ na temperatura no Nordeste até 2040, estendendo-se para a região semiárida em 2041-70, entre $2^{\circ} \mathrm{C}$ e $4^{\circ} \mathrm{C}$, e para toda a região até 2100 , acima de $4^{\circ} \mathrm{C}$. Da mesma forma, a redução da precipitação deve afetar principalmente a parte ocidental da região (mais de 1,5 mm / dia de redução) e a região semiárida $(0,4$ a $0,8 \mathrm{~mm} /$ dia de redução). A figura 2 mostra o resultado das projeções derivadas do downscaling do modelo HadCM3 usando o modelo regional Eta CPTEC (MARENGO; BERNASCONI, 2015).

Estudos reunidos pelo Painel Brasileiro de Mudanças Climáticas (PBMC), inspirado no modelo do IPCC, apontam a região Nordeste como uma das mais vulneráveis às mudanças climáticas, especialmente a população que vive no semiárido nordestino (PBMC, 2014; IPCC, 2014). As alterações na temperatura e precipitação irão afetar bacias hidrográficas importantes do país, como a do rio São Francisco, fonte do maior projeto de infraestrutura hídrica já executado no país, que pode sofrer efeitos distintos na disponibilidade de água para o consumo humano e processos ecológicos (PMBC, 2014).

A bacia do rio São Francisco, origem da água que será transportada pelo PISF, é observada por diferentes estudos. É importante ressaltar que o nível da barragem de Sobradinho, na Bahia, é que irá condicionar o volume a ser transportado pelos eixos Norte e Leste, como será detalhado no capítulo 6.

Sabe-se, que o ciclo de seca mais recente, iniciado em 2012, trouxe impactos preocupantes à bacia do rio São Francisco, como demonstrou o trabalho de Sun et al (2016). Para verificar a disponibilidade de água na bacia, os autores usaram o sistema Gravity Recovery and Climate Experiment (GRACE). Ele consiste em dois satélites da National Aeronautics and Space Administration Espacial (NASA), agência norte-americana, que rodeiam a órbita da Terra desde 2002 e medem as mudanças no campo gravitacional da Terra, diretamente relacionadas às mudanças na massa da superfície. Dessa maneira, é possível medir o armazenamento total de água (TWS) (SUN et al, 2016). 
Figura 2 - Mudança na temperatura anual do ar $\left({ }^{\circ} \mathrm{C}\right.$, a-c); precipitação (mm dia-1, d-f); precipitação-evaporação $\left(\mathrm{mm} \mathrm{dia}^{-1}, \mathrm{~g}-\mathrm{h}\right)$ e umidade relativa do ar $(\%, \mathrm{j}-1)$ derivado do downscaling do modelo HadCM3 usando $40 \mathrm{~km}$ lat-lon do modelo regional Eta

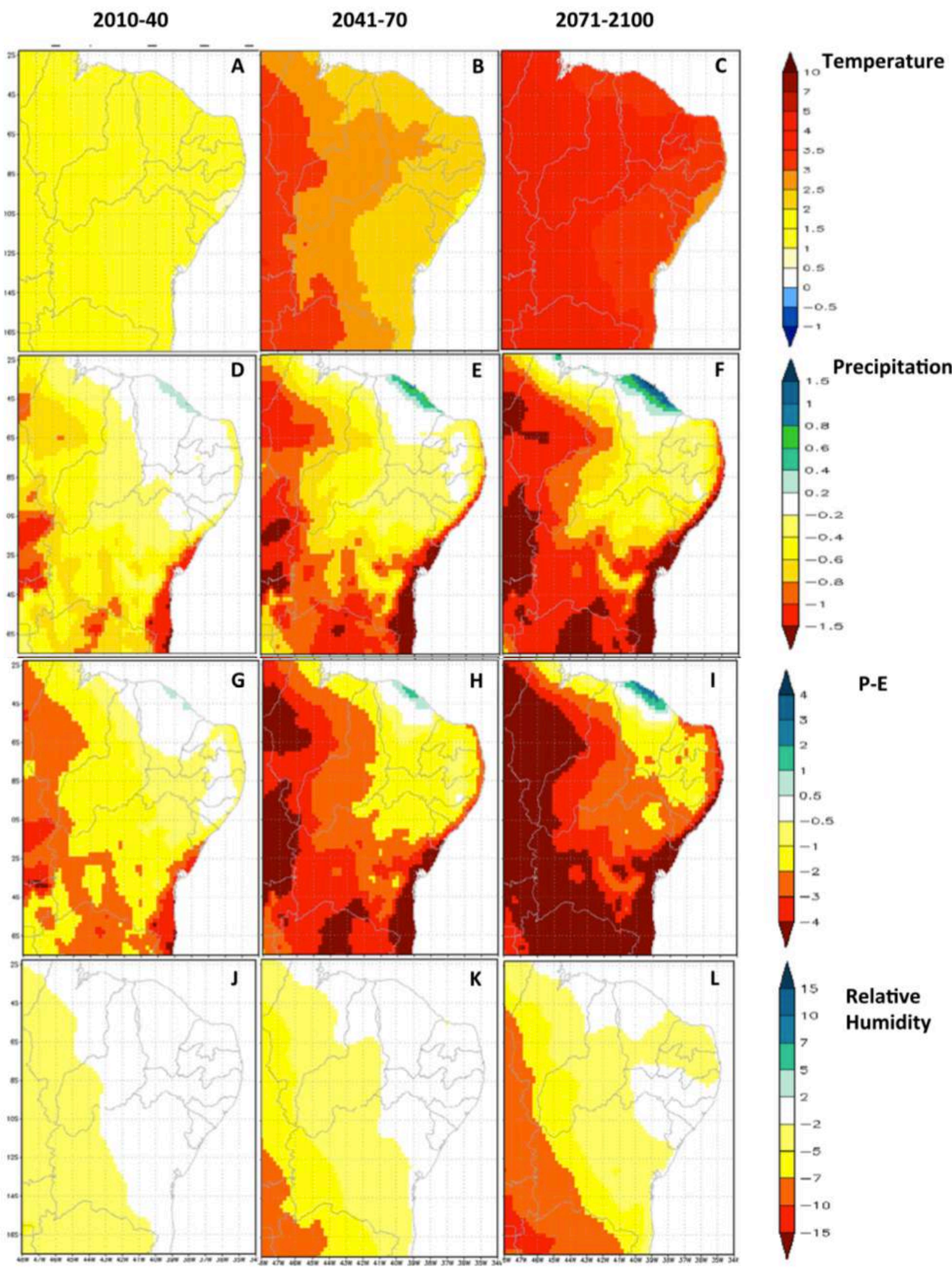

(MARENGO; BERNASCONI, 2015) 
Os autores verificaram uma perda de água de abril de 2002 a março de 2015 na bacia do rio São Francisco a uma taxa de $-3.30 \mathrm{~km} 3 /$ ano. Por outro lado, a perda de água no período de fevereiro de 2012 a janeiro de 2015, anos do mais recente ciclo de seca, foi de $-27.63 \mathrm{~km}^{3}$ / ano, dados que vão ao encontro da queda de precipitação verificada no período, como ilustra a figura 3. Embora o estudo não associe diretamente o evento extremo às mudanças climáticas, os autores não descartam essa possiblidade e afirmam que novas análises das causas para o fenômeno são urgentes (SUN et al, 2016).

Figura 3 - Total de ganho/perda de água em $\mathrm{km}^{3}$ com dados do sistema GRACE de abril de 2002 a março de 2015. Bacia do São Francisco contornada de branco

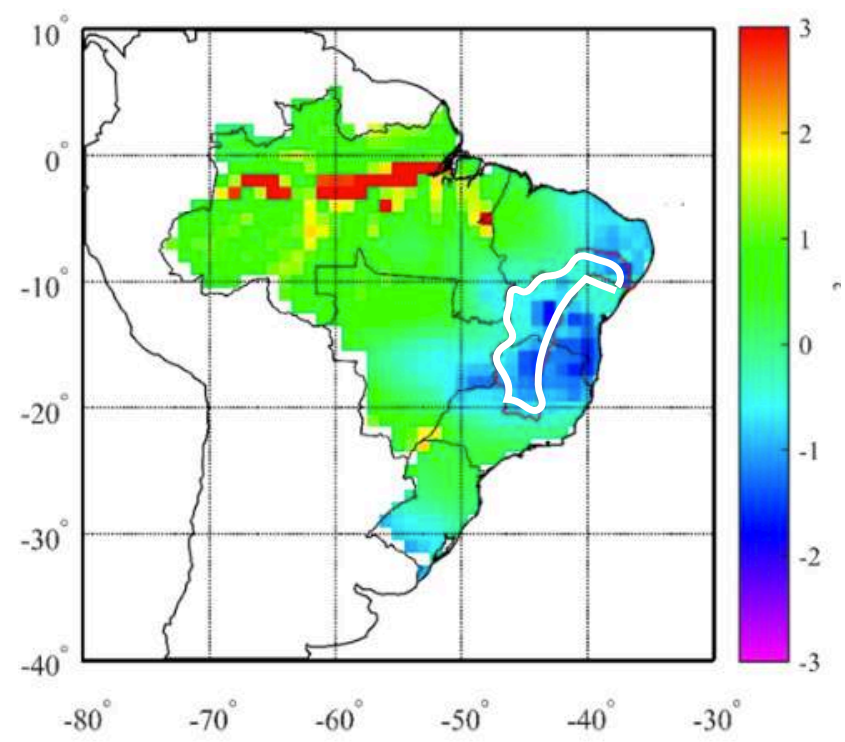

SUN et al, 2016 2015)

Numa escala global, mudanças na disponibilidade da água foram observadas no trabalho publicado por Rodell et al (2018), usando a mesma ferramenta GRACE. Os autores analisaram 34 bacias hidrográficas por meio de dados coletados pelos satélites entre 2002 e 2016. As alterações foram quantificadas e apontam um cenário futuro de escassez em regiões onde esse problema já é recorrente.

Rodell et al (2018) tentam apontar as causas das alterações observadas, como ilustra a figura 4. Os autores concluem que, além da ação do homem e do mau gerenciamento das reservas de água, muitas as observações registradas pelo GRACE estão relacionadas com as mudanças climáticas e projeções de queda nas taxas de precipitação. 
Figura 4 - Tendência em TWS (centímetros por ano) obtidas com base nas observações do GRACE de abril de 2002 a março de 2016

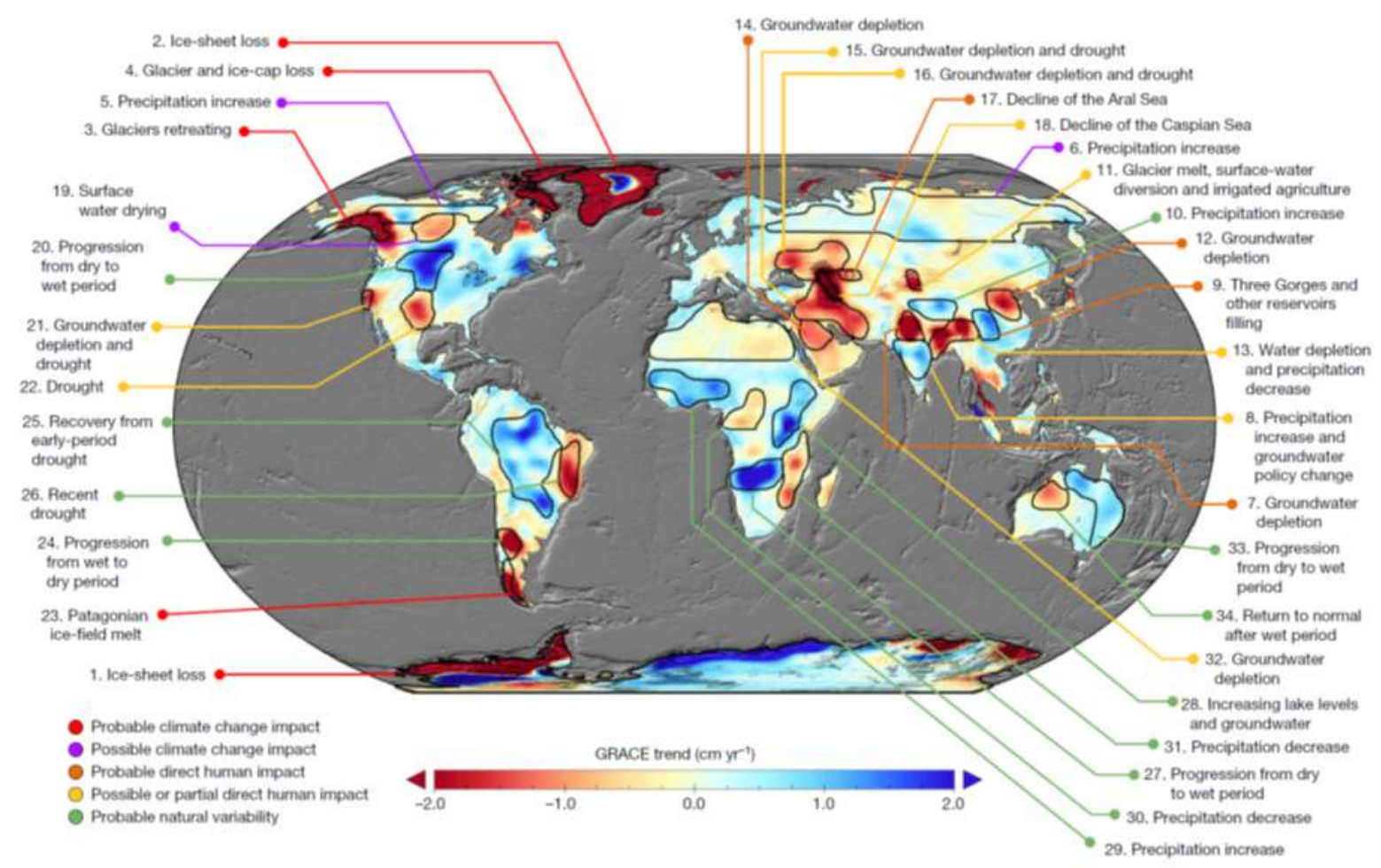

Fonte: Rodell et al (2018)

A questão da adaptação às mudanças climáticas, portanto, se mostra extremamente relevante. O debate do tema vem ganhando espaço crescente na literatura e nas mesas de negociações climáticas como provável reflexo da falha do processo político em mitigar as mudanças climáticas. O processo de adaptação, no entanto, é complexo e não pode ser resumido a um conjunto de atividades bem delimitadas (BASSET; FOGELMAN, 2004; SCHIPPER, 2006; FÜSSEL, 2007a; SMIT, 1999).

Autores afirmam que a discussão sobre a necessidade de adaptação surge normalmente a partir de experiências com eventos extremos. Portanto, quando se considera a população afetada e suas vulnerabilidades, a variabilidade climática e as mudanças climáticas provocadas pela ação do homem precisam ser consideradas ao mesmo tempo, visto que os riscos que surgem dessa combinação são maiores (FÜSSEL, 2007a). 


\section{OBJETIVOS}

O presente trabalho tem como objetivo principal analisar o Eixo Leste do Projeto de Integração do Rio São Francisco com Bacias Hidrográficas do Nordeste Setentrional (PISF) no contexto de adaptação às mudanças climáticas, como potencial medida de adaptação.

Esse trabalho tem ainda outros objetivos específicos:

1. Identificar como a distribuição da água ao longo do Eixo Leste do PISF ocorre desde a concepção no projeto original, passando pelo detalhamento até a sua implantação;

2. Analisar os Projetos Executivos considerando a sua finalidade de fornecer segurança hídrica para populações rurais difusas ao longo do Eixo Leste;

3. Explorar o RIMA e o Projeto Executivo do Eixo Leste do PISF sob o ponto de vista de ser uma alternativa de adaptação às mudanças climáticas no semiárido do Nordeste;

4. Compreender os processos decisórios e de governança em torno da disponibilização dos recursos hídricos no domínio do projeto, particularmente quanto ao acesso à água das populações mais vulneráveis.

A originalidade da presente pesquisa pode ser denotada no fato de essa ser uma das primeiras análises feitas após a conclusão do Eixo Leste do PISF, em março de 2017. Além disso, o trabalho se dedica a investigar o impacto do empreendimento de infraestrutura hídrica sob a ótica da adaptação às mudanças climáticas num contexto já marcado por crises de escassez de água, o que pode provocar incapacidade de sobrevivência, estimular migrações e acirrar conflitos sociais.

Tendo em vista o avanço das mudanças climáticas e seus impactos no semiárido brasileiro, os já observados e previstos, faz-se urgente o debate público de medidas de adaptação no contexto brasileiro, assim como a integração de resultados de pesquisa científica no planejamento de grandes obras de infraestrutura hídrica, com foco nas populações mais vulneráveis. Essa pesquisa tem o objetivo de contribuir com o avanço da discussão da temática no Brasil com um abordagem interdisciplinar, que será cada vez mais exigida para a solução de problemas complexos, como é o caso das mudanças climáticas. 


\section{METODOLOGIA}

Para responder a pergunta, o trabalho de pesquisa se baseou numa concepção pragmática. Segundo Creswell (2014), essa concepção se preocupa com as aplicações e as soluções para os problemas. Buscam-se diferentes abordagens disponíveis para entender o problema, assim como compreensão dos contextos sociais, históricos e políticos.

A complexidade do tema estudado e sua interdisciplinaridade impõem o uso de diferentes estratégias, visto que a aplicação simples de metodologias dedutivas poderiam ser insuficientes. Embora parte considerável do trabalho seja ancorado na literatura das ciências climáticas, que se desenvolveram mantendo suas raízes na Física e acabaram colocando no centro de suas pesquisas o aumento da capacidade de prever cenários futuros com maior precisão, os fenômenos descritos por essa ciência ocorrem no mundo real, que é um sistema aberto, gerido por múltiplas estruturas causais, mecanismos, processos e campos (CORNELL; PARKER, 2010; BHASKAR, 2010).

A estratégia de investigação aplicada nesse trabalho se enquadra na pesquisa qualitativa, apoia-se em documentos, imagens, entrevistas não estruturadas e visitas de campo, seguindo as definições de Creswell (2014). O trabalho é divido em oito capítulos, o primeiro, segundo e terceiro fazem a introdução, explicam o objetivo e metodologia. Os quatro que se seguem oferecem subsídios teóricos de diferentes áreas do conhecimento para uma análise integrada do tema dessa dissertação.

O capítulo quatro consiste no levantamento bibliográfico em torno das previsões dos impactos das mudanças climáticas no semiárido do Nordeste brasileiro, assim como as alterações já observadas. Caracteriza-se a região semiárida em termos geográficos, de população e suas vulnerabilidades. Apresenta-se ainda a Política Estadual de Enfrentamento às Mudanças Climáticas de Pernambuco, único estado que contém uma política que discute mudanças climáticas dentre os que recebem o Eixo Leste do PISF.

O quinto capítulo faz uma revisão teórica do conceito de adaptação às mudanças climáticas, discutindo a sua origem e crescente relevância, e o conceito baseado em vulnerabilidade, adotado nesse trabalho. Aborda ainda a aplicação da teoria na política brasileira voltada ao enfrentamento das mudanças climáticas. 
O capítulo seis dessa pesquisa discute a construção de infraestruturas hídricas para transferir volumes entre bacias hidrográficas, visando o combate à escassez nas bacias receptoras. Por meio de levantamento bibliográfico, retomou-se o histórico do projeto de transposição do rio São Francisco, a polêmica que antecedeu o início das obras, o contexto da tomada de decisão de se levar a obra adiante. Nessa parte, é feita a análise de documentos oficiais de organismos estatais, empresas de engenharia e de consultoria atuantes no empreendimento, assim como análise de documentos de acesso restrito ao público, como Projeto Executivo do Eixo Leste e Projeto Executivo dos Sistemas de Uso Difuso. Essas foram etapas longas e importantes dessa pesquisa.

O sétimo capítulo dessa dissertação apresenta as observações feitas nas duas visitas de campo na região do Eixo Leste do PISF. A primeira delas, em março de 2017, marcou a ocasião da conclusão das obras do Eixo Leste. Em março de 2018, uma nova visita foi feita com o intuito de acompanhar as operações um ano após o seu início. O trabalho de campo teve o objetivo de verificar e analisar "in loco" as reais condições do referido projeto no Eixo Leste. Entrevistas não estruturadas com representantes das cidades de Floresta e Monteiro, cidades onde o Eixo Leste começa e termina respectivamente, foram feitas nas duas ocasiões. Moradores de comunidades do entorno e produtores rurais também foram entrevistados.

O conteúdo apresentado nos capítulos anteriormente citados é discutido numa análise qualitativa que integra os conceitos teóricos, os documentos oficiais, os registros fotográficos e entrevistas feitos nas duas visitas de campo. A última parte desse trabalho apresenta as conclusões e recomendações para pesquisas futuras. 


\section{CAPÍTULO 4: MUdANÇAS CLIMÁTICAS E O SEMIÁRIDO DO NORDESTE BRASILEIRO}

\subsection{CARACTERIZAÇÃO DA REGIÃO SEMIÁRIDA BRASILEIRA}

O Nordeste do Brasil foi a primeira área do país a ser ocupada pelos portugueses, com a chegada de Pedro Álvares Cabral, em 1500. O povoamento teve início no século XVI, com a colonização do seu litoral e a exploração dos sertões. O Censo Demográfico de 2010 identificou um crescimento populacional de $11,19 \%$ em relação a 2000 , saindo de 47,7 milhões para 53,1 milhões de habitantes. A taxa de crescimento foi, portanto, próxima à média nacional $(12,48 \%)$ e semelhante à do Sudeste (11,16\%) (LEITE; SOUZA, 2012).

A região é uma das cinco que atualmente compõem o território nacional, abrange nove Estados e ocupa uma área total de 1.553.917,1 km2 (Tabela 1).

Tabela 1 - Estados que formam a região Nordeste: dados sobre capital, área e população

\begin{tabular}{llll}
\hline Estado & Capital & Área $(\mathrm{km} 2)$ & População \\
\hline Maranhão & São Luis & $331.935,507$ & 6.574 .789 \\
Piauí & Teresina & $251.576,644$ & 3.118 .360 \\
Ceará & Teresina & $148.920,538$ & 8.452 .381 \\
Rio Grande do Norte & Natal & $52.810,699$ & 3.168 .027 \\
Paraíba & João Pessoa & $56.469,466$ & 3.766 .528 \\
Pernambuco & Recife & $98.146,315$ & 8.796 .448 \\
Alagoas & Maceió & $27.779,343$ & 3.120 .494 \\
Sergipe & Aracaju & $21.918,354$ & 2.068 .017 \\
Bahia & Salvador & $564.830,859$ & 14.016 .906 \\
\hline
\end{tabular}

Fonte: IBGE, censo 2010 
É nessa região que se encontra a porção semiárida brasileira, definida segundo a metodologia de classificação climática de Thornthwaite (1948), que adicionou o balanço hídrico climatológico à equação, considerada clássica na literatura de climatologia. O Índice de Aridez proposto pelo autor calcula a diferença entre a precipitação e a perda de água do sistema (evapotranspiração). O semiárido é definido por taxas de evapotranspiração maiores que a precipitação.

No Brasil, uma reclassificação foi proposta pelos Ministérios de Integração Nacional e do Meio Ambiente em 2005, que adotou novos critérios técnicos para delimitar a porção semiárida. Segundo a reclassificação, passaram a fazer parte da região municípios que têm uma das três características a seguir: precipitação média anual inferior a 800 milímetros, índice de aridez de até 0,5 calculado pelo balanço hídrico que relaciona as precipitações e a evapotranspiração potencial no período entre 1961 e 1990; e risco de seca maior que 60\% tomando-se por base o período entre 1970 e 1990 (BRASIL, 2005).

Sob o ponto de vista geológico, de solos e de clima, o semiárido nordestino foi dividido em sete unidades geossistêmicas: (1) Depressão Sertaneja; (2) Planaltos Sedimentares; (3) Planalto da Borborema; (4) Planaltos com Coberturas Calcárias; (5) Maciços Serranos Residuais; (6) Chapada Diamantina e Encostas do Planalto Baiano, (7) Tabuleiros préLitorâneos e parte da Planície Costeira. Em todas essas unidades, o bioma prevalente é o da caatinga, ou "mata branca", segundo a linguagem indígena (BRASIL, 2005).

Obedecendo os critérios da reclassificação adotada, 1.262 municípios de nove estados se encontram nos limites do semiárido, o que corresponde a $11,53 \%$ do território nacional. A maior parte deles está na região Nordeste. Como ilustra a figura 5 , dentre os nove estados que têm uma porção semiárida, a maior extensão está no Rio Grande do Norte (92,97\%), seguido por Pernambuco $(87,60 \%)$, Ceará $(86,74 \%)$, Paraíba $(86,20 \%)$, Bahia $(69,31 \%)$, Piauí $(59,41 \%)$, Sergipe (50,67\%), Alagoas $(45,28 \%)$ e Minas Gerais (17,49\%) (MEDEIROS et al, 2012).

Em 2010, de acordo com o último censo do Instituto Brasileiro de Geografia e Estatística, IBGE, a população residente no semiárido era de 22.598 .318 habitantes, o que equivale a $11,85 \%$ da população total, $42,57 \%$ da população nordestina ou ainda $28,12 \%$ da população residente do Sudeste. Da população total residente no semiárido, estima-se que $61,97 \%$ vivam no meio urbano e 38,03\% no meio rural (MEDEIROS et al, 2012). 
Figura 5 - Mapa que mostra a delimitação do Semiárido Brasileiro

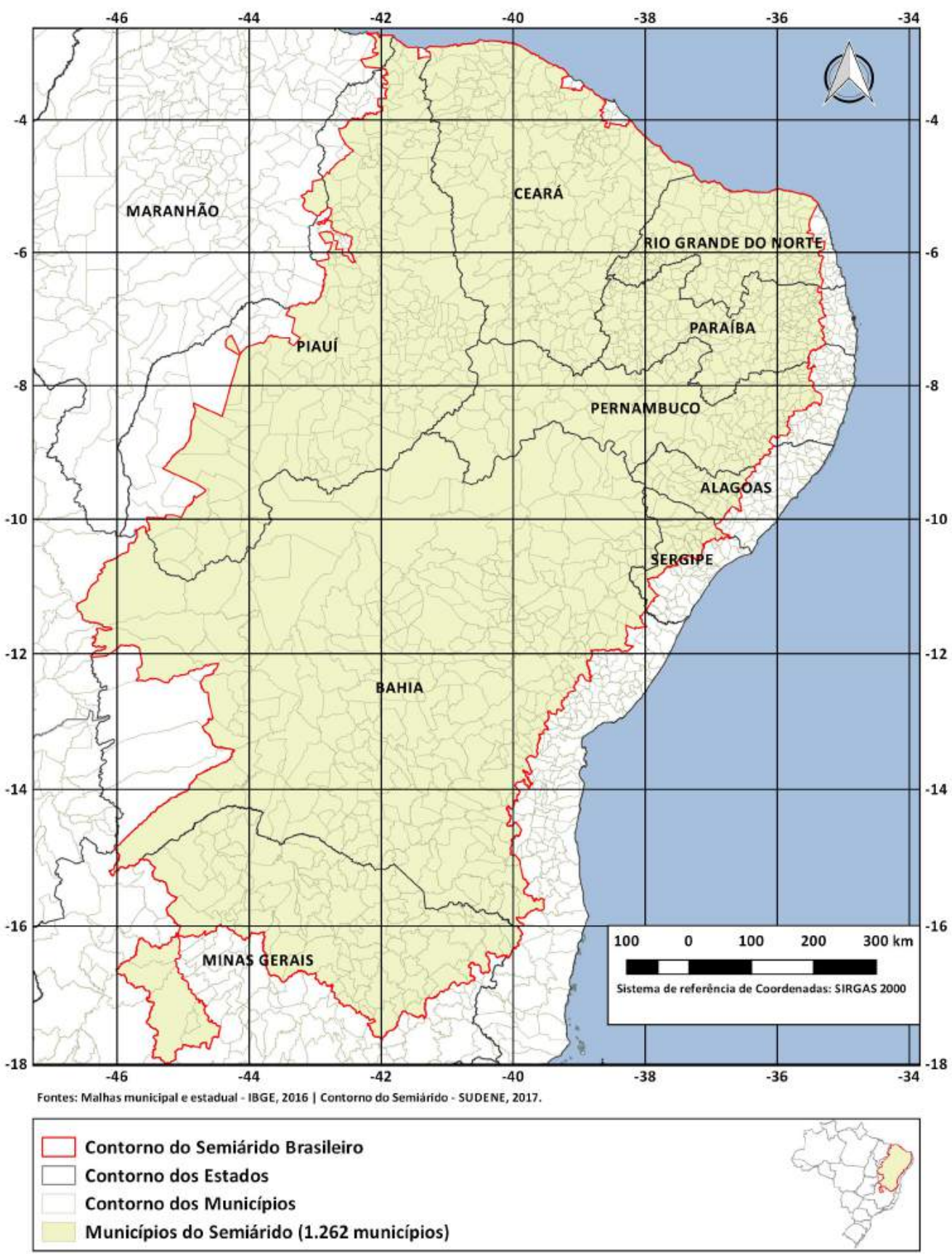

Fonte: INSA, 2018 
Paralelamente às condições climáticas, o Nordeste apresenta baixos índices de desenvolvimento social e econômico, o que contribui para tonar a região a mais vulnerável às mudanças climáticas do país (MARENGO et al, 2011). A pobreza e a extrema pobreza são mais intensas no Norte e Nordeste do país, totalizando cerca de 11 milhões dos 17 milhões de brasileiros que vivem nessa situação. No Norte e Nordeste, cerca 16\% da população vive abaixo da linha da pobreza, a maior parte (60\%), no campo (SOARES, et al, 2016).

Embora o histórico de seca seja conhecido, assim como as condições climáticas marcadas pela irregularidade das chuvas, pode-se afirmar que a população que vive no semiárido nordestino ainda não se adaptou. A água é armazenada de forma ineficiente, é escassa entre as populações rurais difusas que praticam a agricultura de subsistência, e concentra-se sob o poder de poucos. A combinação acirra os conflitos sociais em torno da água (MARENGO et al, 2011).

Devido às condições climáticas e irregularidade de chuva, a região é afetada historicamente por secas. Num levantamento histórico, Marengo, Torres e Alves (2017) identificaram que o fenômeno natural é relatado desde o século XVI, precisamente 1583 . Desde então, foram registrados pelo menos 48 eventos de seca, o mais recente deles com início em 2012 e ainda em andamento. Dentre os efeitos desse fenômeno que atingiram a região ao longo do tempo destacam-se vários fatos dramáticos, como a morte da metade da população no Nordeste e de $85 \%$ das criações de animais na seca de 1777-1780; morte de até 500 mil pessoas ao longo do século XIX; migração de cerca de 10 mil nordestinos afetados pela seca (MARENGO; TORRES; ALVES, 2017).

A região apresenta, em média, precipitação acumulada inferior a $600 \mathrm{~mm} \mathrm{ano}^{-1}$. Na maior parte desse espaço geográfico, a estação seca se estende de agosto a outubro, e o período chuvoso ocorre entre os meses de fevereiro a maio. Esse regime de chuvas, associado às características do solo, limita a existência dos rios intermitentes em muitas localidades (MEDEIROS et al, 2011; MARENGO et al, 2011).

Dessa forma, a elevação gradual da temperatura do ar, a possível diminuição das chuvas e aumento da perda evaporativa de água do solo podem tornar inviáveis os cultivos agrícolas que ainda permanecem no semiárido entre as populações rurais que praticam subsistência. Sem acesso a equipamentos ou irrigação, esses cultivos de milho, feijão, mandioca dependem do volume e regularidade das chuvas (NOBRE et al, 2011). 


\subsection{MUDANÇAS CLIMÁTICAS NO SEMIÁRIDO BRASILEIRO}

No Brasil, a região Nordeste é uma das mais vulneráveis às mudanças climáticas, especialmente a população que vive no semiárido é mais suscetível. Portanto, as questões relacionadas à vulnerabilidade e adaptação devem ser tratadas, inclusive com criação de modelos que levem em consideração as necessidades dos países em desenvolvimento, como o Brasil (MARENGO, 2006).

O clima do Nordeste Brasileiro é marcado por uma grande variabilidade sazonal e intrasazonal, interanual e interdecenal. A zona de convergência intertropical (ZCIT) é considerada um dos principais sistemas que provocam chuvas na região nos meses de março a junho. Ela varia de posição e intensidade, apresenta a convergência dos ventos alísios do Norte e Sul no Atlântico, com movimentos ascendentes, baixas pressões, nebulosidades e chuvas abundantes e segue, na maior parte, as regiões onde a temperatura da superfície do mar é mais alta. Outro sistema formador de chuva importante na região são os Vórtices Ciclônicos do Ar Superior (VCAS), que provocam precipitação em janeiro e fevereiro (CAMPOS, 2011; MARENGO et al, 2011).

Atuam ainda sobre clima na região a ocorrência dos fenômenos El Niño e La Niña, que são resultado da interação entre atmosfera e oceano influenciados respectivamente pelo aquecimento e resfriamento das águas do Oceano Pacífico. Eles ocorrem em intervalos que variam entre 2 e 7 anos e causam impactos sobre a chuva do Nordeste. Da mesma forma, as circulações atmosféricas e oceânicas do Atlântico Tropical interferem na variabilidade climática do semiárido (MARENGO et al, 2011).

Embora sua grande variabilidade seja conhecida, por outro lado, mudanças nos padrões climáticos da região estão sendo observadas, como relata o Grupo de Trabalho II (GT-II) do IPCC, que analisa a vulnerabilidade dos sistemas humanos e naturais frente ao impacto das mudanças climáticas, além das suas consequências e as possibilidades de adaptação. Segundo o AR5 do IPCC, apesar de sua grande variabilidade interanual, a precipitação no Nordeste tem apresentado queda desde a década de 1970. A figura 6 reúne as principais mudanças observadas nos últimos 60 anos (MAGRIN et al, 2014). 
Figura 6 - Principais mudanças observadas no Nordeste do Brasil nos últimos 60 anos

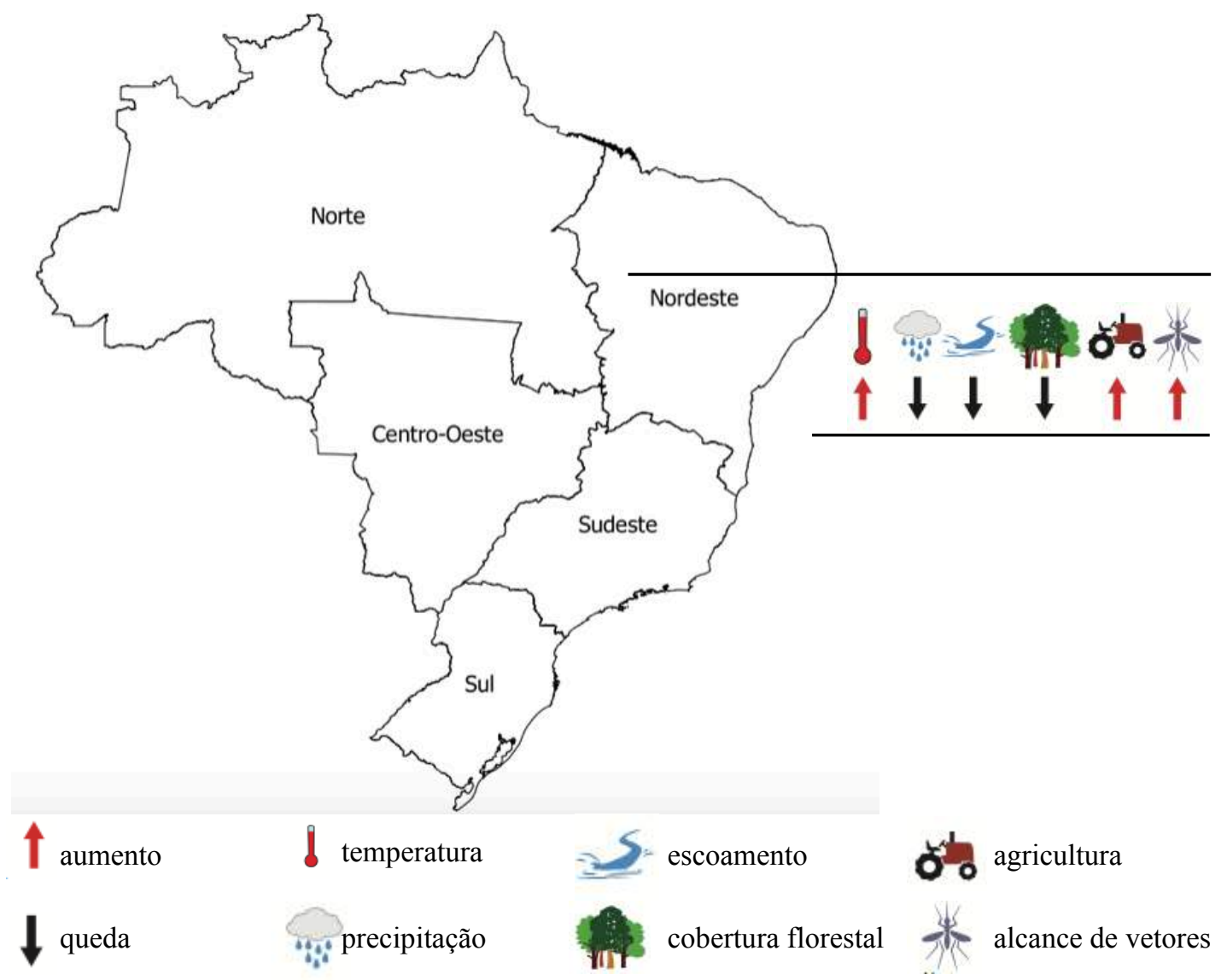

Fonte: modificado de MAGRIN, et al, 2014

Em regiões como Vitória do Santo Antão, cidade de 137 mil habitantes no interior do estado de Pernambuco localizada a 52 quilômetros da capital Recife, a temperatura subiu $3^{\circ} \mathrm{C}$ nos últimos 40 anos. Também em Pernambuco, Nobre (2011) reuniu evidências de mudanças climáticas demonstradas no aumento de temperatura diária entre 1961 e 2009 na estação meteorológica de Araripina, com aumento de $4^{\circ} \mathrm{C}$ na temperatura máxima. No mesmo período, com base em dados de oito postos pluviométricos localizados no vale do rio Pajeú, identificou-se uma redução de $275 \mathrm{~mm}$ do total das chuvas anuais, o equivalente a $57 \%$. O rio Pajeú é um afluente importante do rio São Francisco. Com uma área de 16.685 km2, a bacia hidrográfica do Pajeú é a maior do estado de Pernambucoํํ (NOBRE, 2011).

\footnotetext{
${ }^{1}$ Informação disponível em http://cbhsaofrancisco.org.br/o-tal-do-rio-pajeu-que-despeja-no-sao-francisco/
} 
Até o fim do século, a situação pode se agravar. As projeções indicam que a redução das chuvas pode chegar a $22 \%$ até 2100 , com aumento do número de dias e noites quentes e ocorrência de eventos extremos, como secas prolongadas. Esse cenário impacta diretamente as reservas de água e sua disponibilidade para agricultura por meio da irrigação. Consequentemente, é esperada uma baixa na produtividade agrícola na região em curto prazo, até 2030, o que coloca em risco a segurança alimentar principalmente da população mais pobre. Ficam ameaçados, portanto, cultivos tradicionais de subsistência como feijão, milho e mandioca, com esperada redução de áreas favoráveis a esses tipos de cultura devido ao aumento de temperatura. Outro efeito previsto diante desses impactos das mudanças climáticas é diminuição de renda, o que pode levar a fluxos intensos de imigração (MAGRIN et al, 2014).

As alterações na temperatura e precipitação irão afetar bacias hidrográficas importantes do país, aponta o Relatório de Avaliação Nacional (RAN1), do PBMC. Por cortarem regiões vulneráveis às mudanças climáticas, estão nesse grupo de risco as bacias do São Francisco, Amazonas, Tocantins-Araguaia, Paraná e Paraguai, que devem sofrer efeitos distintos na disponibilidade de água para o consumo humano e processos ecológicos (PMBC, 2014, p.13).

\footnotetext{
"Os cenários apontam para diminuição na pluviosidade nos meses de inverno em todo país, assim como no verão no leste da Amazônia e Nordeste. Da mesma forma, a frequência de chuvas na região Nordeste e no Leste da Amazônia (Pará, parte do Amazonas, Tocantins, Maranhão) deve diminuir, com aumento na frequência de dias secos consecutivos. Este cenário deverá impor um stress sério aos já escassos recursos hídricos da região Nordeste.”
}

Pesquisadores do PBMC que compilaram o RAN1, afirmam que são fortes os indícios de que, ao longo do século XXI, a disponibilidade dos recursos hídricos diminuirá, quer por interferências climáticas e antrópicas, quer pelo simples aumento de demanda.

O ciclo hidrológico está diretamente ligado às mudanças de temperatura da atmosfera e ao balanço de radiação. Com o aquecimento da atmosfera, devem ocorrer mudanças nos padrões de precipitação, como aumento de intensidade e de variabilidade, o que poderão afetar a disponibilidade e a distribuição temporal de vazão nos rios de modo significativo (PMBC, 2014).

Problemas com a disponibilidade de água e as secas devem aumentar em regiões semiáridas a baixas latitudes (IPCC, 2014). No Brasil, atenção especial deve ser dada à região 
do semiárido nordestino, que já tem alto potencial para evaporação de água em função da incidência de horas de sol e de suas altas temperaturas do ar. Nobre et al (2011) apontam que, em relação às projeções de disponibilidade hídrica para o Nordeste até 2100, uma intensificação ou aumento da frequência do El Niño Oscilação Sul ocasionaria a ocorrência de eventos climáticos extremos na região: diminuição do total de chuvas ou aumento da intensidade de chuvas, associado a uma atmosfera mais quente.

Marengo et al (2012) usaram o modelo regional Eta-CPTEC/HadCM3 para fazer projeções referentes às mudanças climáticas nas bacias da Amazônia, São Francisco e Paraná. Para a bacia do rio São Francisco, área de interesse do presente trabalho, os autores previram uma redução de 35\% da média anual de precipitação até 2100 .

De Jong et al (2018) usaram as projeções de Marengo et al (2012) num estudo voltado para prever a capacidade de geração de energia hidrelétrica na bacia do rio São Francisco. Depois de analisar vários modelos do IPCC e dados históricos, a conclusão é que a queda de $35 \%$ na média anual de precipitação para a bacia do São Francisco poderia ocorrer já em 2050.

Desde 1992, a média anual de precipitação na bacia tem sido menor que a média histórica anual observada entre 1961 e 1990. A análise dos dados de precipitação apontaram uma queda de mais de 25\% em 2017 em relação à media anual verificada entre 1961-1990. Consequentemente, a queda na vazão da bacia do rio São Francisco em 2017 foi de 33\% em relação à média verificada entre 1931-90. Dessa forma, a produção de energia hidrelétrica na região ficaria inviável em anos de estiagem a partir de 2030 (DE JONG et al, 2018).

Embora existam incertezas quanto à alteração exata do ciclo hidrológico no Nordeste, há um certo grau de concordância quanto aos cenários de aumento de temperatura média do ar e frequência de ondas de calor e noites quentes. Dessa maneira, pode-se esperar um aumento da perda de água por evapotranspiração, o que impacta na diminuição da disponibilidade hídrica, de forma especial na umidade do solo. Quanto ao semiárido, os modelos indicam com clareza um aumento do déficit hídrico anual para o fim do século XXI. A diminuição das chuvas acarretaria uma menor recarga dos lençóis freáticos do Nordeste, com uma redução que poderia chegar a 70\% (NOBRE et al, 2011; MARENGO et al, 2011, NOBRE, 2012).

Num trabalho de modelagem para aprimorar previsões de mudanças climáticas para a América do Sul, Chou (2014) se baseou em projeções do modelo Eta aninhadas a dois 
Modelos Climáticos Globais (GCM, na sigla em inglês): HadGEM2-ES e MIROC5. Os cenários de emissões de gases de efeito estufa considerados foram RCP 8.5 e RCP 4.5, adotados no quinto relatório do IPCC (AR5). Essas são, respectivamente, as trajetórias representativas de concentrações de $\mathrm{CO}_{2}$ (Representative Concentration Pathways, RCP, no termo em inglês) mais pessimista e mais otimista, que correspondem a forçante radiativa de $8,5 \mathrm{Wm}^{-2}$ e 4,5 $\mathrm{Wm}^{-2}$. Na prática, o RCP 8.5 poderia levar a um aquecimento de $4^{\circ} \mathrm{C}$ até 2100 , e o RCP 4.5 provocaria a elevação de $1^{\circ} \mathrm{C}$ na temperatura média.

Foram produzidas quatro simulações: HadGEM2-ES para RCP 4.5 e RCP 8.5 e duas MIROC5 para os dois mesmos RCPs. Embora os dois GCMs apresentem algumas diferenças nas simulações, o trabalho de Chou (2014) apontou que um aquecimento é previsto para todo o continente. Os dois modelos (HadGEM2-ES e MIROC5) também indicam redução de precipitação até o fim do século. Aumento do números de dias secos consecutivos foi previsto para a região Nordeste do Brasil.

A diminuição da chuva e aumento da evapotranspiração, além da seca e degradação do solo, podem levar, a longo prazo, a um processo de desertificação. Essa perda biológica, produtividade econômica e dos ecossistemas representam uma ameaça aos processos ecológicos, biogequímicos e hidrológicos. Projeções feitas por Marengo e Bernasconi (2015) indicaram o aumento do risco de transição do clima semiárido para árido em regiões do Nordeste.

Uma análise dos recursos hídricos no Nordeste publicada pela Agência Nacional de Águas (ANA) apontou conclusões semelhantes. Segundo a publicação, um aumento de $3^{\circ} \mathrm{C}$ ou mais na temperatura média deixaria ainda mais secos os locais que já sofrem com déficit hídrico no semiárido. Além disso, o elevado potencial para evaporação, combinado com o aumento de temperatura, ocasionaria queda no nível de água de lagos, açudes e reservatórios. Uma maior frequência de dias secos consecutivos e de ondas de calor aceleraria a degradação do solo, tornando inviável a agricultura de subsistência e ameaçando a sobrevivência das comunidades na região (NOBRE, 2012). 


\subsection{POLÍTICA ESTADUAL DE ENFRENTAMENTO ÀS MUDANÇAS CLIMÁTICAS DE PERNAMBUCO}

O estado de Pernambuco, cujo parte do território semiárido recebe o Eixo Leste do PISF, instituiu em 2010 a Política Estadual de Enfrentamento às Mudanças Climáticas de Pernambuco. Dentre as questões abordadas, a adaptação é definida como um conjunto de iniciativas e estratégias que permitem a adaptação, nos sistemas naturais criados ou pelos homens, a um novo ambiente, em resposta à mudança do clima atual ou esperada. Já vulnerabilidade é entendida como grau em que um sistema é suscetível ou incapaz de absorver os efeitos adversos da mudança do clima, incluindo a variação e os extremos climáticos; função da característica, magnitude e grau de variação climática ao qual um sistema é exposto, sua sensibilidade e capacidade de adaptação (PERNAMBUCO, 2010).

Quanto à adaptação, fazem parte dos objetivos da Política Estadual apoiar iniciativas e projetos que a favoreçam; suporte à educação, pesquisa, desenvolvimento e divulgação de tecnologias e medidas de adaptação, assim como a elaboração de um plano que contribua para adaptação (PERNAMBUCO, 2010).

A Política Estadual criou estratégias de mitigação e adaptação em 19 diferentes áreas, a saber: energia, transporte, indústria e mineração, setor público, agropecuária, biodiversidade e florestas, recursos hídricos, resíduo e consumo, construção civil, saúde, oceano e gestão costeira, semiárido e desertificação, uso do solo e cobertura vegetal urbana, instrumentos de comando e controle. Destacam-se a nomeação do poder público como órgão responsável pela alocação e aplicação de recursos destinados à pesquisa em busca de alternativas para a adaptação da sociedade e ecossistemas às mudanças climáticas (PERNAMBUCO, 2010).

No que se refere aos recursos hídricos em específico, a Política Estadual prevê a definição de áreas de maior vulnerabilidade, assim como implantação de medidas de mitigação e adaptação em função das mudanças climáticas visando a garantia de água em qualidade e quantidade para uso múltiplo (PERNAMBUCO, 2010).

Como instrumento, a Política Estadual previu a elaboração do Plano Estadual de Mudanças Climáticas, publicado em 2011. De antemão, o documento do estado de Pernambuco reconhece a vulnerabilidade de seu território frente às mudanças climáticas previstas pelo IPCC, dentre as quais o avanço da desertificação, com a identificação de 135 municípios em áreas sujeitas a esse fenômeno, onde vivem aproximadamente 2,5 milhões de 
pessoas. O déficit hídrico é apontado como um fator limitante à vida e ao desenvolvimento (PERNAMBUCO, 2011).

Dentre as prioridades apontadas no plano são elencadas o apoio à educação, pesquisa e desenvolvimento de divulgação de tecnologias de combate à mudanças climáticas e de medidas de adaptação e mitigação; elaboração de planos de ação que contribuam com para mitigação ou adaptação aos impactos das mudanças climáticas nos diferentes níveis de planejamento estadual e ambiental. Quanto às populações vulneráveis, o plano estimula programas e iniciativas de educação e conscientização sobre o tema mudanças climáticas, sem necessariamente direcionar a esse grupo ações prioritárias de adaptação (PERNAMBUCO, 2011).

Foram estipuladas pelo Plano Estadual de Enfrentamento às Mudanças Climáticas de Pernambuco metas mínimas quanto à adaptação, de relevância para a presente análise, destacando-se a elaboração do Zoneamento Ecológico Econômico do semiárido com a inclusão de questões advindas do efeitos das mudanças climáticas; diagnóstico dos sistemas naturais das bacias hidrográficas com a identificação das disponibilidades hídricas e sua evolução frente aos cenários de aquecimento para os anos de 2020, 2030, 2040 e 2050; identificação das áreas críticas sujeitas à desertificação; elaboração do mapa de vulnerabilidade ambiental do semiárido (PERNAMBUCO, 2011). 


\section{CAPÍTULO 5: MUDANÇAS CLIMÁTICAS E ADAPTAÇÃO}

É cada vez mais notória a relação entre o aumento da concentração dos gases estufa em decorrência da atividade humana e o ritmo de mudanças no sistema natural da Terra. O quinto e mais recente relatório do Painel Intergovernamental de Mudanças Climáticas (IPCC) conclui que o aquecimento climático é inequívoco, relata ainda que muitas dessas mudanças observadas desde a década de 1950 são sem precedentes, nunca tendo sido registradas nas últimas décadas e milênios. A atmosfera e oceanos estão mais quentes, a quantidade de neve e gelo diminuíram, e o nível do mar subiu (IPCC, 2014).

Os níveis na atmosfera dos principais gases estufa (dióxido de carbono, metano, óxido nitroso) continuam subindo, com a concentração de $\mathrm{CO} 2$ atingindo marca recorde, acima de 400 partes por milhão (ppm) em 2015 (BLUNDEN; ARNDT, 2016).

Nesse contexto, o tema da adaptação às mudanças climáticas ganhou considerável atenção nas últimas duas décadas. Em termos quantitativos, o destaque é relevante: em revistas especializadas como a Global Environmental Change, por exemplo, 85\% dos artigos dedicados ao tema foram publicados desde 2005. A mesma tendência numérica aparece em relatórios publicados pelo IPCC: desde 2007, o número de capítulos dedicados à discussão dobrou, segundo observaram Basset e Fogelman (2003).

$\mathrm{Na}$ área de mudanças climáticas, até então, as discussões científicas estiveram mais focadas na mitigação, e havia uma separação marcante entre os temas na maneira de se discutir, na prática e no planejamento de políticas públicas (SCHIPPER, 2006).

A mudança de perspectiva registrada ao longo das décadas recentes se deve a alguns fatores importantes. Um deles é a constatação mais precisa feita nos últimos dois relatórios do IPCC, publicados em 2007 e 2014, de que as mudanças climáticas estão em curso e seus efeitos são observados globalmente de forma inequívoca. Tais evidências levaram o próprio órgão, além de outros setores da sociedade, a considerar medidas para reduzir a vulnerabilidade às condições existentes e previstas (KATES, 2000; SCHIPPER, 2006).

Outro motivo para o aprofundamento do debate em torno da adaptação é a falha do processo político em mitigar as mudanças climáticas, como apontado por Basset e Fogelman (2003). Segundo a análise de literatura feita por Schipper (2006), é possível identificar as causas que afastaram o tema da adaptação da agenda de ações governamentais e das mesas de 
negociações internacionais. Até meados da década de 1990, o assunto era percebido apenas como uma opção, ou seja, dar atenção a ele seria um reconhecimento formal de que as medidas de mitigação seriam ineficientes ou inefetivas. Portanto, discutir adaptação às mudanças climáticas era visto como não-construtivo. Em resumo, no campo político, o debate era conduzido como uma escolha entre mitigação e adaptação.

A própria dificuldade em torno de uma definição do conceito impôs uma barreira para que o tópico fosse aprofundado na agenda dos governos e das negociações internacionais. A situação era um reflexo da falta de conhecimento teórico e prático, fruto da pouca atenção dada ao assunto pela comunidade científica (KLEIN, 2003; SCHIPPER, 2006).

Embora seja relativamente novo no estudo das mudanças climáticas, o conceito de adaptação tem um longo histórico em áreas correlacionadas, como ecologia, desastres naturais e gerenciamento de riscos (SMIT et al, 1999).

Por outro lado, Füssel (2007a) ressalta que diferentes aspectos relacionados especificamente à adaptação às mudanças climáticas adicionam um ineditismo ao debate. Dentre eles estão condições climáticas sem precedentes observadas em algumas regiões, o ritmo em que essas mudanças estão ocorrendo, nível avançado de conhecimento sobre o clima que não existia em sociedades de épocas passadas, desafios metodológicos, participação de novos atores e necessidade de novas medidas. A tabela 2, adaptada do trabalho de Schiffer (2003), resume a evolução do conceito de adaptação na literatura.

No campo da ação política, o tópico adaptação apareceu pela primeira vez na agenda dos pequenos estados insulares em desenvolvimento (SIDS, na sigla em inglês), em 1992, na World Conference on Environment and Development, a Rio 92 (SCHIPPER, 2006). Essa conferência marcou a fundação da Convenção-Quadro das Nações Unidas sobre Mudanças Climáticas (UNFCCC), com o principal objetivo de estabilizar as concentrações de gás do efeito estufa na atmosfera de forma que previna a interferência antropogênica danosa no sistema climático².

\footnotetext{
2 Documento base assinado na ocasião da fundação da UNFCCC disponível em https://unfccc.int/resource/docs/ convkp/conveng.pdf
} 
Tabela 2 - Evolução do debate conceitual sobre adaptação às mudanças climáticas

\begin{tabular}{|c|c|c|c|}
\hline $\begin{array}{l}\text { Temporal - } \\
\text { Décadas }\end{array}$ & Fórum & Principais perguntas & Estratégias \\
\hline \multicolumn{4}{|c|}{ Debate sobre Mudanças Climáticas } \\
\hline 1960-1970 & $\begin{array}{l}\text { Organização Mundial } \\
\text { Meteorológica } \\
\text { Cientistas climáticos }\end{array}$ & $\begin{array}{l}\text { Precisamos nos preocupar com } \\
\text { mudanças climáticas? } \\
\text { Como mudanças climáticas irão } \\
\text { afetar o tempo? }\end{array}$ & $\begin{array}{l}\text { Modificação do tempo } \\
\text { (weather), } \\
\text { monitoramento }\end{array}$ \\
\hline $\begin{array}{l}\text { Meados } \\
1980 \\
- \text { início } \\
1990\end{array}$ & $\begin{array}{l}\text { IPCC } \\
\text { INC } \\
\text { UNFCCC COP }\end{array}$ & $\begin{array}{l}\text { Mudanças climáticas estão } \\
\text { acontecendo? } \\
\text { Como mudanças climáticas irão } \\
\text { afetar ecossistemas e a } \\
\text { humanidade? } \\
\text { Quem deveria ser responsável pela } \\
\text { redução de emissões? }\end{array}$ & $\begin{array}{l}\text { Regime de redução de } \\
\text { emissões globais, } \\
\text { implementação } \\
\text { conjunta de atividades }\end{array}$ \\
\hline $\begin{array}{l}\text { Fim 1990- } \\
\text { início } 2000\end{array}$ & $\begin{array}{l}\text { UNFCCC COP } \\
\text { Órgãos legisladores } \\
\text { regionais }\end{array}$ & $\begin{array}{l}\text { Quais são os custos relativos da } \\
\text { mitigação e adaptação? } \\
\text { Quão vulnerável são as } \\
\text { comunidades à variabilidade e suas } \\
\text { consequências? }\end{array}$ & $\begin{array}{l}\text { Estratégias planejadas } \\
\text { de adaptação }\end{array}$ \\
\hline
\end{tabular}

\section{Adaption Thinking}

Quais os limites ecológicos para o desenvolvimento humano e crescimento?

1970-início Clube de Roma 1980 Acadêmicos

Fim 1980 Advirory Group on Greenhouse Gases IPCC

$\begin{array}{ll}\text { Início } 1990 & \text { IPCC } \\ & \text { INC }\end{array}$

(continua)
Como respondemos às mudanças climáticas?

Quais tipos de impactos o sistema suporta?

Os sistemas irão se adaptar automaticamente?

Quais serão os impactos? $\mathrm{O}$ quanto a sociedade e ecossistemas são capazes de se adaptar?

Em que medida a capacidade adaptativa pode offset a necessidade de mitigação?

Mitigação é mais importante que adaptação para responder às mudanças climáticas? Mitigação e adaptação como alternativas para responder às mudanças climáticas.
Adaptação individual

Adaptação dos ecossistemas

\section{UNFCCC}


(continuação)

\begin{tabular}{|c|c|c|c|}
\hline $\begin{array}{l}\text { Temporal - } \\
\text { Décadas }\end{array}$ & Fórum & Principais perguntas & Estratégias \\
\hline \multicolumn{4}{|c|}{ Adaption Thinking } \\
\hline Fim 1990 & $\begin{array}{l}\text { UNFCCC COP } \\
\text { Órgãos de pesquisa }\end{array}$ & $\begin{array}{l}\text { Como a política pode apoiar a } \\
\text { adaptação? } \\
\text { Quem é vulnerável às mudanças } \\
\text { climáticas e por que? } \\
\text { Mudanças climáticas irão acontecer } \\
\text { - adaptação será necessária. } \\
\text { Ligação entre adaptação e } \\
\text { desenvolvimento }\end{array}$ & $\begin{array}{l}\text { Avaliação de impactos } \\
\text { e vulnerabilidade } \\
\text { Políticas de adaptação }\end{array}$ \\
\hline Início 2000 & $\begin{array}{l}\text { ONU, } \\
\text { Global Environmental } \\
\text { Facitily, } \\
\text { Banco Mundial e } \\
\text { agências doadoras, } \\
\text { Orgãos de pesquisa, } \\
\text { IPCC }\end{array}$ & $\begin{array}{l}\text { O que constitui uma capacidade } \\
\text { adaptativa? } \\
\text { Como adaptação pode ser integrada } \\
\text { em planos de desenvolvimento } \\
\text { sustentável? } \\
\text { O que é necessário to mainstream } \\
\text { adaptação? } \\
\text { Como política de adaptação pode } \\
\text { ser feita? }\end{array}$ & $\begin{array}{l}\text { Programas de } \\
\text { desenvolvimento de } \\
\text { políticas e projetos de } \\
\text { agencias multilaterais e } \\
\text { agências doadoras } \\
\text { bilaterais }\end{array}$ \\
\hline
\end{tabular}

Fonte: Schipper (2006)

No contexto da negociação política, o debate sobre adaptação evoluiu com a história da UNFCCC. Foi após o lançamento do terceiro relatório do IPCC, em 2001, que a adaptação foi introduzida na agenda da Convenção. A UNFCCC define adaptação como ajuste em sistemas naturais ou humanos em resposta a estímulos climáticos reais ou esperados ou seus efeitos. ${ }^{3}$

No intuito de aprimorar a ciência da adaptação às mudanças climáticas, diferentes tipologias foram propostas para classificar como a adaptação ocorre, em termos de processo e forma. Smit et al (1999) resumiram os principais termos usados na literatura, como ilustra a tabela 3.

Num sistema natural, livre da influência humana, por exemplo, a adaptação ocorre de forma autônoma (intenção/propósito) e reativa (momento). Quando se considera um processo de adaptação iniciado por um agente público, ele normalmente é planejado (intenção/ propósito) e antecipatório (momento), como destacam Smit et al (1999).

\footnotetext{
3 Definição do glossário da UNFCCC disponível em: https://unfccc.int/process-and-meetings/the-convention/ glossary-of-climate-change-acronyms-and-terms\#a Acessado em 30.05.2018
} 
Embora muitos dos atributos listados na tabela sejam apenas descritivos, o termo "execução" inclui uma ideia de avaliação, como o custo do processo, sua eficiência e efetividade. E esse é um fator central em projetos de adaptação às mudanças climáticas.

Num esforço para analisar pré-requisitos que definam uma adaptação bem-sucedida, Füssel (2007a) discorre sobre o desafio em lidar com o tema, já que medidas de adaptação às mudanças climáticas não podem ser resumidas a um conjunto de atividades bem delimitadas.

Por conseguinte, as abordagens podem ser diversas e precisam ser avaliadas no contexto específico em que a adaptação precisa ocorrer. Não existe, portanto, uma abordagem única flexibilidade e particularidades metodológicas produzem resultados que são relevantes para o caso em discussão e que auxiliam na tomada de decisão (FÜSSEL, 2007a; SMIT et al, 1999).

Segundo Füssel (2007a), a discussão sobre a necessidade de adaptação normalmente surge a partir de experiências com eventos extremos. $\mathrm{O}$ autor defende que, quando esses fenômenos expõem a vulnerabilidade da região ou população afetada, a variabilidade climática e as mudanças climáticas provocadas pela ação do homem precisam ser consideradas em conjunto, justamente porque é a combinação desses dois fatores que aumenta os riscos.

Para que medidas planejadas de adaptação tenham o efeito esperado, ainda é necessário considerar que elas não se encerram num período delimitado, mas são contínuas, e que informações precisas sobre as condições climáticas futuras reduzem consideravelmente o custo total da adaptação (FÜSSEL, 2007a).

Sobre essa diversidade de ações consideradas de adaptação às mudanças climáticas, podem ser citadas medidas relacionadas ao gerenciamento de recursos naturais, gerenciamento de recursos hídricos, preparação para lidar com desastres, planejamento urbano, criação de redes de monitoramento, mudanças na estrutura institucional para aumentar eficiência das decisões políticas, incentivos fiscais, fomento da participação social nas decisões públicas, desenvolvimento sustentável, redução da pobreza, entre outros (KLEIN, 2003; FÜSSEL, 2007a). 
Tabela 3 - Principais termos usados na literatura de adaptação às mudanças climáticas

\begin{tabular}{lll} 
Conceito ou Atributo & \multicolumn{2}{l}{ Exemplos de termos usados } \\
Intenção / propósito & Autônoma & Planejada \\
& Espontânea & Intencional \\
& Automática & Política \\
& Natural & Ativa \\
& Passiva & Estratégica \\
Momento & Antecipatória & Responsiva \\
& Proativa & Reativa \\
Escopo temporal & Ex ante & Ex post \\
& Curto prazo & Longo prazo \\
& Tática & Estratégica \\
& Instantânea & Cumulativa \\
Escopo espacial & Contingencial & \\
Funções/Efeitos & Rotineira & \\
& Localizada & Difundida \\
Forma & Retirar - Acomodar - Proteger - Prevenir Tolerar \\
Execução & - Expandir - Mudar - Restaurar \\
& Estrutural - Legal - Institucional - Regulatória \\
& Financeira - Tecnológica \\
\hline
\end{tabular}

adaptado de Smit et al. (1999) 


\subsection{ADAPTAÇÃO ÀS MUDANÇAS CLIMÁTICAS BASEADA NA VULNERABILIDADE}

A vulnerabilidade às mudanças climáticas tem sido objeto de estudo pesquisadores de campos diferentes: ciências da terra, gestão de desastre, estudos relacionados ao desenvolvimento, ciências humanas, saúde, economia entre outros. Consequentemente, a literatura voltada ao tema pode apresentar termos diversos como vulnerabilidade, resiliência, adaptação, capacidade adaptativa, risco, perigo, sensibilidade, para citar alguns (BROOKS, 2003; FÜSSEL, 2007b).

A presente pesquisa adota termos definidos por Brooks (2003) numa revisão de literatura de conceitos-chaves para o estudo da adaptação. "Perigo" é entendido como manifestações físicas da variabilidade climática ou mudanças climáticas como secas, tempestades, enchentes, entre outros. Portanto, o termo "perigo" neste trabalho está ligado a eventos climáticos.

O conceito de "vulnerabilidade" nesse contexto das mudanças climáticas pode ser compreendido como biofísico e social. A vulnerabilidade biofísica, ou física, está ligada aos impactos de um evento de perigo e pode ser relacionada à quantidade de danos sofridos num sistema como resultado de um evento de perigo. Alguns indicadores para esse tipo de vulnerabilidade são medidas monetárias dos custos, mortalidade, danos para o ecossistema, entre outros (BROOKS, 2003; JONES; BOER, 2003).

Já a vulnerabilidade social é determinada por fatores como desigualdade, pobreza, déficit alimentar, déficit educacional, falta de acesso a serviços de saúde, más condições habitacionais (BROOKS, 2003). A combinação das vulnerabilidades biofísica e social podem, portanto, causar perdas de vidas, bens, provocar altos custos públicos entre outros.

Após o debate em torno do tema adaptação ter se intensificado nas últimas décadas, organizações internacionais desenvolveram uma série de diretrizes para auxiliar na análise de estratégias. Orientações mais genéricas são listadas em manuais publicados pelo IPCC (CARTER et al, 1994), UNEP Handbook (FEENSTRA et al., 1998), UNDP-GEF Adaptation Policy Framework (LIM et al, 2005).

As abordagens aplicadas nas diretrizes recomendadas pelas publicações citadas seguem principalmente dois tipos: abordagem baseada nos riscos e abordagem baseada na 
vulnerabilidade. A primeira foca nos impactos adicionais das mudanças climáticas e depende fortemente de modelagem climática e projeções dos impactos. Ela não leva em consideração, por exemplo, aspectos menos técnicos como capacidade adaptativa, condições sociais que determinam a vulnerabilidade e o contexto político (FÜSSEL, 2007b).

Já a abordagem baseada na vulnerabilidade dá forte peso a fatores sociais que influenciam a habilidade de uma região ou população quando se considera adaptação às mudanças climáticas. Essa abordagem é importante para identificação das áreas prioritárias, na análise de efetividade de medidas específicas de intervenção, na análise da relação entre riscos relacionados ao clima e de riscos não climáticos, na análise da limitação dos recursos como dados, dinheiro, tempo e expertise. A adaptação é altamente dependente do contexto específico porque depende de condições climáticas, ambientais e políticas da região ou setor em questão (LIM et al, 2005; FÜSSEL, 2007b).

Nessa mesma direção, a análise de Klein (2003) ressalta o que ele chama de desenvolvimentos não-climáticos que estão ligados intimamente à adaptação. Esses ocorrem num contexto social dinâmico, em que muitos atores diferentes representam interesses distintos. Portanto, é complexo identificar as melhores e mais apropriadas estratégias de adaptação com base no equilíbrio entre seus custos e benefícios.

O trabalho de Klein (2003) mostrou que analisar os custos financeiros e os benefícios das opções de adaptação disponíveis é complexo, consideravelmente mais complexo que analisar as opções de mitigação.

Diante dos desafios, é recomendado que medidas de adaptação à variabilidade climática sejam pensadas como um ponto de partida. A adoção de estratégias para reduzir a vulnerabilidade de regiões e populações à variabilidade climática já conhecida também demonstra a capacidade, iniciativa e habilidade de um país para se adaptar às mudanças climáticas (KLEIN, 2003).

De qualquer maneira, nenhuma medida de adaptação, quer seja à variabilidade climática ou às mudanças climáticas, será bem-sucedida se os aspectos naturais específicos da região, sociais e culturais não forem considerados. Nenhuma opção irá funcionar num ambiente que não está preparado, não tem capacidade ou não quer receber a medida em questão. Para Klein (2003), o incremento das capacidades tecnológica, industrial, legal e econômica, assim como a conscientização são pré-requisitos para uma adaptação efetiva. 


\subsection{ADAPTAÇÃO ÀS MUDANÇAS CLIMÁTICAS NO BRASIL}

Seguindo a tendência internacional, as primeiras discussões no Brasil em torno do tema mudanças climáticas focaram na mitigação. Dentre os documentos oficias que endereçaram o tema destacam-se o Plano Nacional sobre Mudanças do Clima, publicado em 2008, e a Lei Nacional que instituiu a Política Nacional sobre Mudanças do Clima, em 2009.

O primeiro apresenta medidas de mitigação voluntárias voltadas principalmente à mudança do uso da terra, além de ações para reduzir emissões dos setores de energia, transporte, edificações, indústria e resíduos. Já a Política Nacional, de 2009, estabeleceu as diretrizes e criou instrumentos, permitiu a implantação de mecanismos de mercado para apoiar a mitigação de emissões e estabeleceu a necessidade de Planos Setoriais. O documento reconhece a necessidade de medidas de adaptação às mudanças climáticas e a identificação de vulnerabilidades, seguindo indicação do Plano Nacional (BRASIL, 2008; 2009).

Num trabalho que analisou a abordagem de políticas brasileiras voltadas ao tema, Obermeier e Rosa (2013) destacam o foco em medidas de mitigação, inclusive no que se refere ao espaço dedicado à discussão: enquanto que o Plano Nacional apresenta oito páginas no capítulo "impactos, vulnerabilidade e adaptação", 56 páginas discutem a utilização de biocombustíveis como medida de mitigação.

Quando se refere à adaptação, o Plano Nacional define como planejamento a identificação dos impactos ambientais decorrentes da mudança do clima e o fomento de pesquisas científicas para que sejam traçadas estratégias que minimizem os custos socioeconômicos de adaptação do país. Embora o Plano Nacional reconheça que as populações mais pobres são as mais vulneráveis à mudança do clima e que promover melhores condições de moradia, alimentação, saúde, educação e emprego é parte do processo, o documento demonstra preferência pela abordagem baseada em riscos para tomar decisões. "Vale dizer, por fim, que não há cenários climáticos confiáveis no Brasil capazes de direcionar o processo de adaptação" (pag. 88, Brasil, 2008).

$\mathrm{Na}$ análise de Obermeier e Rosa (2013), a discussão pende para a necessidade de identificação mais precisa dos impactos da mudança do clima para que as incertezas nas previsões climáticas sejam reduzidas o que, portanto, diminui o peso da importância de estudos que identifiquem causas e efeitos da vulnerabilidade e, assim, mudanças para sistemas 
resilientes no futuro. E ainda: quando cita a região do semiárido, a identificação de impactos e vulnerabilidades nos documentos oficiais citados não consideram de forma apropriada as vulnerabilidades socioeconômicas e ambientais existentes.

Em 2016, o governo brasileiro publicou o Plano Nacional de Adaptação à Mudança do Clima com o objetivo de oferecer orientação técnica e política para as ações que visam reduzir riscos climáticos frente aos efeitos associados à mudança do clima. São apresentados três objetivos específicos: 1) Ampliação e disseminação do conhecimento científico, técnico e tradicional: produção, gestão e disseminação de informação sobre o risco climático; 2) Coordenação e cooperação entre órgãos públicos e a sociedade civil; 3) Identificação e proposição de medidas para promover a adaptação e a redução do risco climático. Segundo o documento, até 2040 o Plano deve contribuir para o aumento da capacidade de adaptação no país e para redução de riscos climáticos de forma sistêmica (BRASIL, 2016).

Foram considerados 11 setores no Plano Nacional de Adaptação à Mudança do Clima: agricultura, biodiversidade e ecossistemas, cidades, desastres naturais, indústria e mineração, infraestrutura (energia, transportes e mobilidade urbana), povos e populações vulneráveis, recursos hídricos, saúde, segurança alimentar e nutricional e zonas costeiras. Porém, o documento enumera segurança alimentar e nutricional, hídrica e energética como áreas prioritárias, afirmando que as medidas implantadas precisam dialogar com as metas nacionais de desenvolvimento socioeconômico, redução das desigualdades regionais (BRASIL, 2016).

Em comparação ao Plano Nacional sobre Mudança do Clima, o Plano Nacional de Adaptação à Mudança do Clima tem uma abordagem transversal, considera em seu texto as dimensões social, cultural e econômica, além de grupos mais vulneráveis, listados como populações indígenas, quilombolas e ribeirinhas. Em toda a sua descrição, o Plano Nacional de Adaptação à Mudança do Clima contempla os aspectos teóricos considerados por Basset e Fogelman (2013), Füssel (2007a) e Klein (2006): prevê planos de adaptação integrada, revisão das metas a fim de efetuar um trabalho contínuo, reconhece a importância de se analisar vulnerabilidades, trabalhar com diferentes setores da sociedade e disseminar informação (BRASIL, 2016).

Por outro lado, ainda não existe um plano de implementação publicado, segundo o cronograma estabelecido pelo Plano Nacional de Adaptação à Mudança do Clima, o que impossibilita a avaliação da efetividade das metas. 


\section{CAPÍTULO 6: RECURSOS HÍDRICOS E TRANSPOSIÇÃO ENTRE BACIAS}

Desde a Antiguidade, a transposição de águas entre bacias é usada para suprir regiões que sofrem com a escassez desse recurso natural. Ela se junta a outras soluções de infraestrutura hídrica como construção de reservatórios, recarga de águas subterrâneas, reuso de águas residuais e dessalinização. Em sociedades antigas no Egito, Mesopotâmia, China e Índia, projetos de transposição significavam mais que um método que possibilitava desenvolvimento nas regiões atingidas pela escassez que passavam a ser beneficiadas, mas adquiriram também valor cultural (GOHAKI et al, 2013; HUTCHINSON et al, 2010).

Ao longo da história recente, diversos projetos de transferência de água foram implementados no mundo, com exemplos vindos de países como Austrália, Alemanha, China, Espanha, Estados Unidos, México e Irã. As experiências registraram casos de sucesso, erros, boas práticas e auxiliaram países a criar padrões técnicos e ambientais, assim como tecnologias na área de engenharia. Estima-se que 14\% do abastecimento global de água seja suprido por projetos de transposição, com a expectativa de se atingir 25\% em 2025 (UNESCO, 1999; DE ANDRADE et al, 2011, GOHAKI et al, 2013).

Vistos como alternativa para garantir segurança hídrica, projetos semelhantes também foram empregados no Brasil. O primeiro a ser realizado no país foi a transposição de parte do volume do rio Paraíba do Sul para o rio Guandu, em 1913. Inicialmente planejado para abastecer uma usina hidrelétrica, o empreendimento desviou águas da bacia que corta os estados de São Paulo, Minas Gerais e Rio de Janeiro para a região metropolitana do Rio de Janeiro e possibilitou o desenvolvimento das cidades do entorno. Estudos também analisaram o caso do Sistema Cantareira, construído em meados da década de 1970, que recebeu águas desviadas do rio Piracicaba para suprir a demanda de aproximadamente 8,8 milhões de pessoas na região metropolitana de São Paulo (DE ANDRADE et al, 2011).

Moreira Filho (2006) cita ainda o caso do rio Piumhi e de 22 afluentes no estado de Minas Gerais que, na década de 1960, foram desviados como parte de uma solução para o escoamento da água represada da hidrelétrica de Furnas. O autor relata uma profunda mudança na paisagem da região, diversas alterações ambientais, ausência de estudos e negligência de órgãos responsáveis. 
$\mathrm{Na}$ China, em particular, mais de 20 projetos de transferência de água foram implementados desde a década de 1950. Em todo o globo, soluções do tipo têm sido adotadas, cada vez mais, como opção para suprir diferentes demandas em áreas com problemas de abastecimento. Porém, com o avanço das mudanças climáticas, operações padrão de gerenciamento dessas infraestruturas poderão ser impactadas, o que vai exigir maior precisão no planejamento, design e estágios de operações de grandes projetos de transposição, que exigem grandes investimentos e são construídos com o intuito de operar por séculos (ZHANG et al, 2014).

Por outro lado, Zhang et al. (2014) ressaltam que, diante do atual cenário de mudanças climáticas e seus impactos nas condições hidrológicas, os projetos construídos com estratégias tradicionais de transferência de água podem não funcionar num futuro próximo, o que resultaria num excesso ou escassez do volume desviado. Portanto, faz-se de importância vital a compreensão do desempenho de um projeto de transposição de água num clima em transição.

\subsection{A BACIA HIDROGRÁFICA DO RIO SÃO FRANCISCO}

Nesse contexto, a transposição do rio São Francisco é vista há mais de um século como solução para a escassez de água no semiárido brasileiro. Ele é considerado um dos maiores e mais importantes rios da América do Sul. Em 4 de outubro de 1501, dia de São Francisco de Assis, a expedição exploradora de Américo Vespúcio chegou à foz do imenso rio, entre Alagoas e Sergipe. O nome do rio então foi alterado de Opará, o "rio-mar", como os indígenas o denominavam, para São Francisco (CBHSF, 2016).

O rio tem suas nascentes na Serra da Canastra, no estado de Minas Gerais, e escorre sentido sul-norte. Com $639.219 \mathrm{~km} 2$ de área de drenagem, sua bacia ocupa 7,5\% do território do país, o equivalente à área da França (ANA, 2015). A calha principal do rio percorre 2700 $\mathrm{km}$ e atravessa os estados da Bahia (48,2\%), Minas Gerais (36,8\%), Pernambuco (10,9\%), Alagoas (2,2\%), Sergipe (1,2\%), Goiás (0,5\%) e o Distrito Federal (0,2\%). Segundo o Comitê de Bacia Hidrográfica do rio São Francisco (CBHSF), 507 municípios estão na área de 
abrangência da bacia. Estima-se que 18 milhões de brasileiros vivam em torno da bacia, que tem 168 afluentes.

O rio São Francisco foi um dos primeiros a ganhar no país um Comitê de Bacia Hidrográfica. Ele foi criado em 2001 por meio de um Decreto Presidencial, um ano após o estabelecimento ANA, em 2000. O Comitê de Bacia Hidrográfica do Rio São Francisco é um órgão colegiado com integrantes do poder público, sociedade civil e usuários da água. Sua formação, assim como a de outros comitês, só foi possível graças a mudanças conceituais na administração pública. A Lei Federal n. 9.433, em 8 de janeiro de 1997, promoveu a mudança de uma gestão institucionalmente fragmentada para uma legislação integrada, descentralizada, que deve contemplar seu uso múltiplo e com ampla participação social (BRASIL, 1997, 2001; JACOBI; BARBI, 2007).

Em 2010, foi criada a Associação Executiva de Apoio à Gestão de Bacias Hidrográficas Peixe Vivo, que opera como braço executivo do comitê. Os recursos para sua operação vêm da cobrança pelo uso da água no rio, praticado pelo CBHSF desde 2012. Segundo o comitê, a arrecadação em 2016 foi de R\$ 119 milhões, valor que vem sendo aplicado em projetos de recuperação ambiental e hidroambiental em diversos trechos da bacia (CBHSF, 2016).

O comitê é formado por 62 membros titulares e o mesmo número de suplentes. Os usuários ocupam a maior parte das vagas $(38,7 \%)$, seguido pelo poder público $(32,2 \%)$, sociedade civil $(25,8 \%)$ e comunidades tradicionais $(3,3 \%)$. Cada região da bacia dispõe de uma Câmara Consultiva, que se dedica aos problemas locais. O comitê também é composto por Câmaras Técnicas e Grupos de Trabalho (CBHSF, 2016). A figura 7 e a tabela 4 resumem os principais usos da água ao longo da bacia (CBHSF, 2016). 
Figura 7 - Região Hidrográfica do rio São Francisco

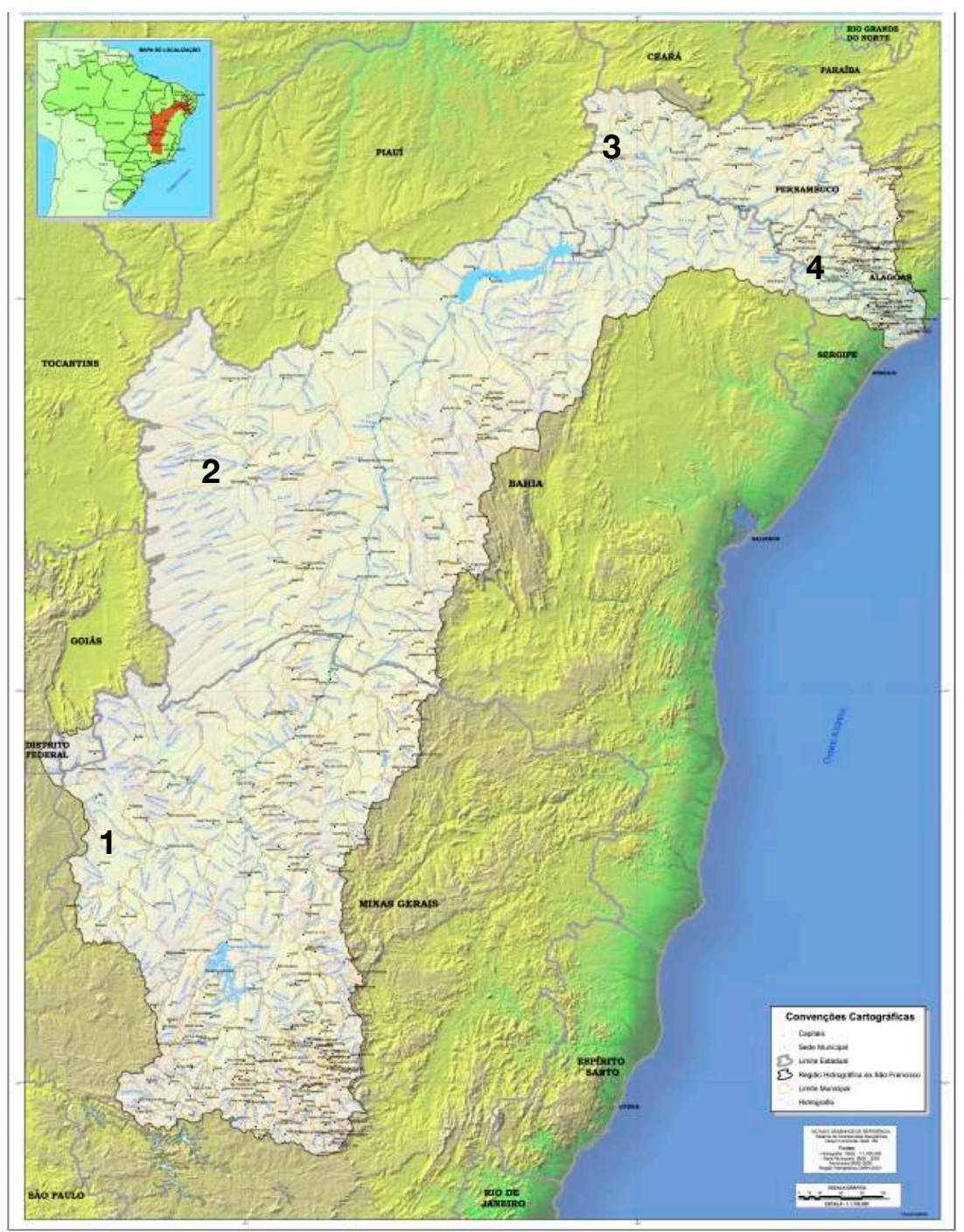

Fonte: ANA, 2015

Tabela 4 - Subdivisão da Bacia Hidrográfica do rio São Francisco

\begin{tabular}{lcccc}
\hline & 1 Alto & 2 Médio & 3 Submédio & 4 Baixo \\
Extensão & $702 \mathrm{Km}$ & $1230 \mathrm{~km}$ & $440 \mathrm{~km}$ & $214 \mathrm{~km}$ \\
Área & $100 \mathrm{~km}^{2}$ & $402 \mathrm{~km}^{2}$ & $110 \mathrm{~km}^{2}$ & $25 \mathrm{~km}^{2}$ \\
Atividade & Industrial & Irrigação & Irrigação & Irrigação \\
\hline
\end{tabular}

Fonte: BETTENCOURT et at, 2016 


\subsection{O PROJETO DE INTEGRAÇÃO DO RIO SÃO FRANCISCO COM BACIAS HIDROGRÁFICAS DO NORDESTE SETENTRIONAL}

O Projeto de Integração do Rio São Francisco com Bacias Hidrográficas do Nordeste Setentrional (PISF) em fase final de execução foi divulgado pelo Ministério da Integração em 2004. Segundo o projeto, a obra foi pensada pela primeira vez em 1875, quando uma grande seca foi registrada no Nordeste. Estima-se que cerca de 1,7 milhão de pessoas tenham morrido em decorrência da seca (MINISTÉRIO DA INTEGRAÇÃO NACIONAL, 2004).

Anteriormente a isso, registros históricos já mostravam alto índice de mortalidade da população no Nordeste em consequência de secas. No evento extremo de 1777-1780, registrou-se o extermínio de $85 \%$ das criações de animais; morte de até 500 mil pessoas ao longo do século XIX; migração de cerca de 10 mil nordestinos afetados pela seca (MARENGO; TORRES; ALVES, 2017).

Embora alguns projetos de interligação das bacias tenham sido cogitados no passado, eles esbarravam na falta de energia elétrica necessária para acionar bombas para a transposição das águas. Apenas na década de 1980, o Departamento Nacional de Obras contra as Secas (DNOS), criado em 1909 como Inspetoria de Obras Contra as Secas, elaborou um anteprojeto de integração do rio São Francisco com as bacias do Semiárido Setentrional (MINISTÉRIO DA INTEGRAÇÃO NACIONAL, 2004).

Esse projeto contou com a participação do United States Bureau of Reclamation (USBR) e propunha captar 15\% da vazão do São Francisco. Mais de uma década depois, em 1994, o estudo foi retomado e sofreu alterações: a retirada, dessa vez, foi diminuída para 7,5\% da vazão. Passados mais de dez anos, o assim chamado Projeto de Integração do Rio São Francisco com Bacias Hidrográficas do Nordeste Setentrional estimou uma transferência média de $2,3 \%$ da vazão do rio em questão. Suas águas serão destinadas às bacias nos estados de Ceará, Paraíba, Rio Grande do Norte e Pernambuco (MINISTÉRIO DA INTEGRAÇÃO NACIONAL, 2004).

Desde sua proposição, o projeto de transposição do São Francisco recebeu críticas e foi alvo de questionamento no âmbito jurídico. Embora o projeto tenha obtido as autorizações necessárias para ser implementado, ele foi questionado diversas vezes na Justiça por 
diferentes entidades sob o argumento de ter desconsiderado preceitos do direito ambiental e a busca pelo desenvolvimento sustentável (HENKES, 2014).

As construções foram iniciadas sem a realização de audiências públicas, como previsto em lei, com elevado número de ações judiciais. Organizações sociais, dentre as quais o CBHSF, mobilizaram protestos contra o empreendimento alegando que ele beneficiaria o setor do agronegócio e não conseguiria, portanto, resolver os problemas da população em geral. Dentre as diversas repercussões negativas apontadas após o inicio da obra estão descrédito na Justiça e no Direito brasileiro, descrédito na gestão hídrica participativa, hiato entre lei e práticas oficiais (EMPINOTI, 2011; HENKES, 2014).

Quando o atual PISF foi apresentando, o CBHSF foi contrário à obra pelos seguintes motivos: concepção equivocada, falta de estudos sólidos, planejamento feito com pressa excessiva e caráter impositivo do projeto (CBHSF, 2016).

O CBHSF se opôs publicamente ao projeto e apontou violações do Plano de Recursos Hídricos da Bacia do São Francisco, elaborado por um grupo técnico de trabalho coordenado pela ANA. Dentre as violações observadas, está a concessão de outorga externa à bacia hidrográfica. Segundo o Plano de Recursos Hídricos da Bacia do São Francisco, poderiam ser autorizados casos referentes exclusivamente ao consumo humano e dessedentação animal que obedecessem os critérios estipulados (CBHSF, 2004; BAHIA, 2010).

Em janeiro de 2005, o Conselho Nacional de Recursos Hídricos (CNRH) aprovou o aproveitamento hídrico para o projeto de transposição e não citou em suas considerações o Plano da Bacia do Rio São Francisco, considerado pela Lei das Águas o principal instrumento de gestão dos seus recursos hídricos (BRASIL, 1997; BAHIA, 2010).

Segundo o CBHSF, o documento que aprovou o aproveitamento hídrico para a transposição não revelou que quase a totalidade da vazão disponível já estava comprometida com outorgas já concedidas, com a reserva para geração de energia elétrica e com a projeção dos usos consuntivos futuros. O comitê questionou ainda o alegado déficit hídrico da região do Nordeste Setentrional, que será beneficiado com as águas do São Francisco (BAHIA, 2010).

Num estudo sobre o uso da água fruto da transposição do São Francisco e investimento público, Ubiratan Goncalves e Fernandes de Oliveira (2009) concluíram que a outorga para uso da água deveria priorizar os projetos de abastecimento ao invés daqueles voltados aos 
grandes projetos de irrigação, visto que a região de inserção do projeto se encontra no domínio do semiárido, portanto, de recorrente escassez hídrica.

No início das obras, autores relataram descaso com direitos territoriais das reservas indígenas, quilombolas e pequenos agricultores, classificando o estilo de desenvolvimento econômico adotado como ultrapassado. O local onde o $2^{\circ}$ Batalhão de Engenharia de Construção ficou baseado durante sua atuação, por exemplo, era um território reivindicado pelo povo truká, no município de Cabrobó, estado de Pernambuco (UBIRATAN GONÇALVES; FERNANDES DE OLIVEIRA, 2009).

Em uma análise crítica do processo de condução do projeto implantado, Bahia (2010) concluiu que a decisão de levar adiante a transposição do rio São Francisco foi política. Quando então as obras de fato se tornaram irreversíveis, o Comitê de Bacia Hidrográfica do Rio São Francisco, apesar da oposição de longa data, aceitou participar do Conselho Gestor do projeto (informação verbal) ${ }^{4}$.

Azevedo (2012) concluiu que não existem projetos de transferência de água que não deixem impactos. Ele sugere que, para que sejam levados adiante, a real magnitude dos impactos e o grau de sustentabilidade das regiões envolvidas sejam muito bem avaliadas. $\mathrm{O}$ autor afirma que os benefícios para a região devem superar os custos advindos dos impactos dos projetos. Ao analisar casos internacionais semelhantes ao PISF, o autor observa que são mais bem-sucedidos aquele que: a) otimizaram uso e aproveitamento do recurso hídrico na bacia receptora; b) identificaram com precisão a demanda existente e de usuários dispostos a pagar, por meio de compromissos legais, o custo de abastecimento de água advindos de tais projetos. Segundo Azevedo (2012), iniciativas que foram adiante sem a definição clara da demanda já estabelecida, sem a definição do arcabouço institucional apropriado e que se destinavam principalmente a induzir o desenvolvimento local por meio da oferta de água enfrentaram dificuldades.

\footnotetext{
44 Informação fornecida por Alberto Schwartzman, diretor técnico da Agência Peixe Vivo em entrevista durante XIII Simpósio de Recursos Hídricos do Nordeste, novembro de 2016.
} 


\subsection{ASPECTOS TÉCNICOS DO PISF}

O Projeto de Integração do Rio São Francisco com Bacias Hidrográficas do Nordeste Setentrional começou a ser implantando após estudos de inserção regional e de viabilidade técnico-econômica que foram apresentados no Relatório de Impacto Ambiental (RIMA). Classificado como um empreendimento de infraestrutura hídrica, o projeto capta água no rio São Francisco entre as barragens de Sobradinho e Itaparica, no estado de Pernambuco. O volume então é levado por meio de canais, estações de bombeamento, reservatórios e usinas hidrelétricas ao longo de dois eixos, o Norte e o Leste. O volume transportado deve beneficiar seis bacias: Jaguaribe (Ceará), Piranhas-Açu e Apodi (Rio Grande do Norte), Paraíba (Paraíba), Moxotó e Brígida (Pernambuco) (MINISTÉRIO DA INTEGRAÇÃO NACIONAL, 2004).

Segundo o Relatório de Impacto Ambiental (RIMA), foram estudadas 22 opções de traçados, numa área de 110 mil km² correspondente a 153 municípios nos estados de Pernambuco, Rio Grande do Norte, Paraíba e Ceará. Decidiu-se que o ponto de captação em Cabrobó (PE) levará uma média de 45,2 $\mathrm{m}^{3}$ de água pelo Eixo Norte, com $402 \mathrm{~km}$ de canais, até os rios Brígida (PE), Salgado (CE), do Peixe e Piranhas-Açu (PB e RN) e Apodi (RN). Segundo o planejamento, sete açudes serão beneficiados por essa parte da estrutura: Chapéu e Entremontes (PE), Castanhão (CE), Engenheiros Ávidos (PB), Pau dos Ferros, Santa Cruz e Armando Ribeiro Gonçalves (RN). Por sua extensão, o Eixo Norte foi dividido em trechos I, II, III, IV, V e VI (MINISTÉRIO DA INTEGRAÇÃO NACIONAL, 2004).

A figura 8 mostra a localização do Projeto Integração do Rio São Francisco com Bacias Hidrográficas do Nordeste Setentrional, com os dois eixos principais, o Norte e Leste, assim como os açudes que serão abastecidos. No Norte: Chapéu, Entremontes (PE); Atalho, Quixabinha, Prazeres, Lima Campos, Orós, Castanhão e Banabuiú (CE); Ávidos, Curemas, São Gonçalo, Lagoa do Arroz (PB); Angicos, Pau dos Ferros, Santa Cruz, Armando Ribeiro (RN). No Leste: Barra do Juá, Poço da Cruz e Ipojuca (PE), Poções, Boqueirão e Acuã (PB). 
Figura 8- Açudes que serão beneficiados pelo PISF

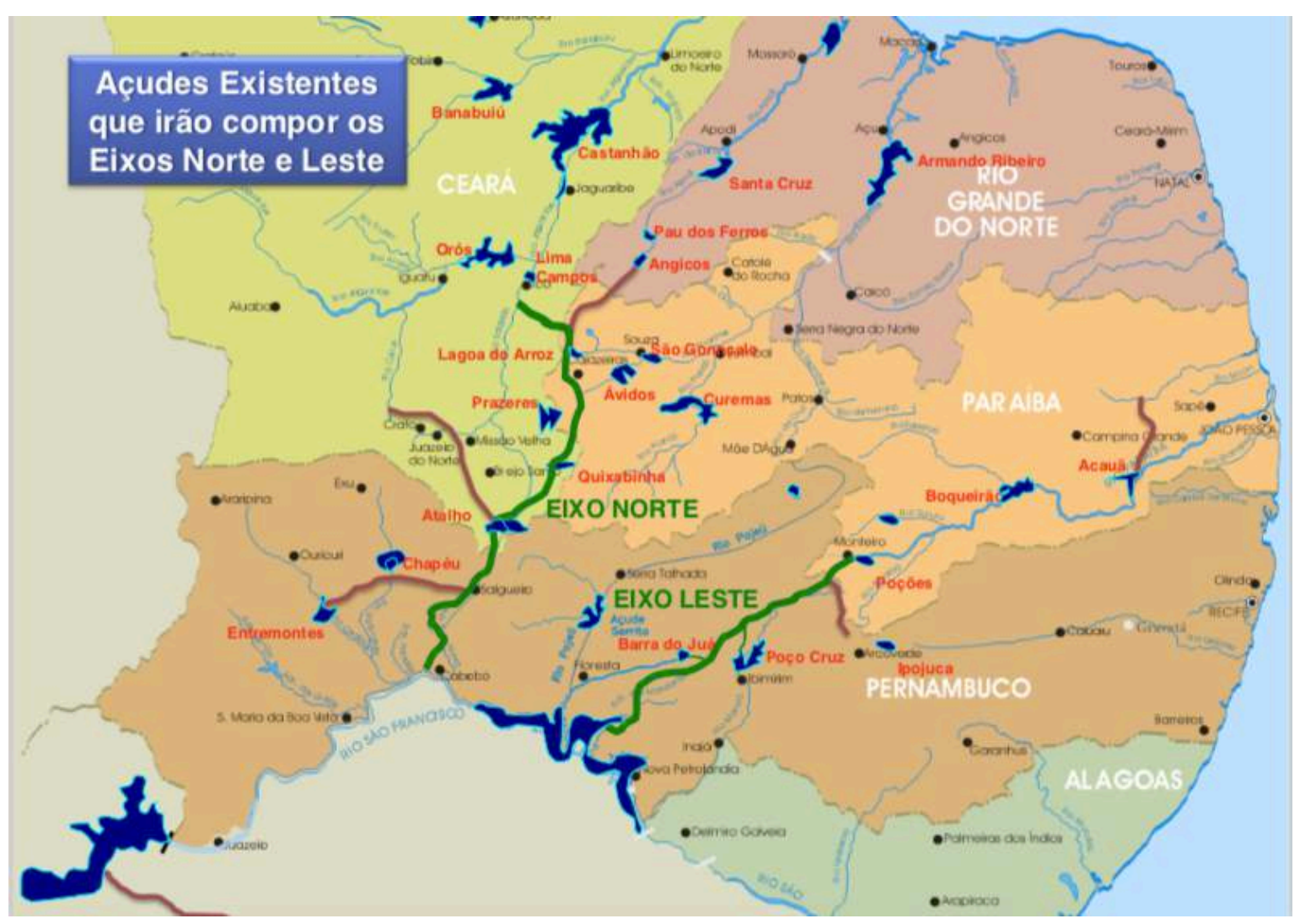

Fonte: Ministério da Integração Nacional, 2017

O Eixo Leste, trecho sobre o qual essa pesquisa está focada, se inicia no ponto de captação em Itaparica e percorre $217 \mathrm{~km}$. A previsão é que seja capaz de transportar, em média, $18,3 \mathrm{~m}^{3}$, chegando até o rio Paraíba, estado da Paraíba. Todo o custo do empreendimento foi estimado, à época da divulgação do RIMA, em US\$ 1,5 bilhão, sendo o mais dispendioso o trecho Norte, orçado em US\$ 1,3 bilhão (MINISTÉRIO DA INTEGRAÇÃO NACIONAL, 2004). Dez anos depois do início de suas obras, os custos atuais estão em R $\$ 9$ bilhões 5 .

\footnotetext{
${ }^{5}$ Informação fornecida pelo ministro da Integração Nacional Helder Barbalho em reportagem publicada pela Deutsche Welle disponível em http://www.dw.com/pt-br/à-margem-do-milagre-do-sãofrancisco/a-38047384
} 
Quando apresentado ao público, em 2004, o cronograma previa a conclusão do projeto para 2010. As obras, no entanto, foram iniciadas em 2007 (NUNES, 2012). Com anos de atraso, as obras no Eixo Leste foram concluídas em março de 2017. A previsão é que as estruturas no Eixo Norte sejam entregues em 2018, segundo informações do MI em março de 2017.

Segundo o MI, o empreendimento do PISF se justifica por garantir que a intervenção irá atender às necessidades de abastecimento de municípios do semiárido brasileiro, Agreste Pernambucano e Região Metropolitana de Fortaleza, sendo apresentado como a solução para os problemas trazidos pela escassez de água nas regiões citadas (MINISTÉRIO DA INTEGRAÇÃO NACIONAL, 2004).

A água transportada pelos dois eixos, Norte e Leste, deve atender até 12 milhões de moradores locais e terá usos diversos como abastecimento humano, irrigação, dessedentação de animais, criação de peixes e de camarão. A expectativa é que o empreendimento viabilize a permanência da população rural no local e melhore as condições de vida, marcada pela pobreza e falta d'água, o que levou grande parcela de nordestinos a migrar para outras regiões do Brasil como consequência da seca. A intervenção pretende também beneficiar a população urbana, pequenos e grandes agricultores, gerar empregos, renda e trazer melhoria na qualidade de vida (MINISTÉRIO DA INTEGRAÇÃO NACIONAL, 2004).

Por estar inserido na área do Polígono das Secas, o projeto pretende oferecer uma parte da água do São Francisco a rios temporários e açudes do semiárido. Portanto, é visto pelo governo como fonte de segurança hídrica para as bacias que vai beneficiar. Por outro lado, o projeto de transposição vai garantir água para uma infraestrutura e sistema de reservação e distribuição já existentes, como açudes, rios e adutoras, no sentido de complementar outros programas de distribuição de água. Do ponto de visto econômico, pretende-se que o PISF promova redução de gastos públicos com programas e medidas de emergência adotadas durante períodos de severa escassez de água, como contratação de caminhões-pipa (MINISTÉRIO DA INTEGRAÇÃO NACIONAL, 2004).

O Decreto 5.995, publicado em 2006, descreve como deve ser o sistema de gestão do projeto de transposição do rio São Francisco. A coordenação será do Ministério da Integração Nacional, tendo a ANA como entidade reguladora. Fazem parte ainda um Conselho Gestor, a 
Companhia de Desenvolvimento dos Vales do São Francisco e do Parnaíba (Codevasf) como operadora federal e operadoras estaduais (BRASIL, 2006).

É atribuição do Conselho Gestor, órgão do qual o CBHSF faz parte, colaborar com a gestão integrada entre os diferentes órgãos federais e da área de recursos hídrico. No entanto, CBHSF definiu como foco que irá acompanhar o estrito cumprimento da outorga concedida pela ANA aos canais de transposição, garantir o uso nacional das águas que serão transportadas nos canais e defender os interesses da população da bacia (CBHSF, 2016).

A outorga estabelecida pela ANA dá ao Ministério da Integração Nacional o direito de uso dos recursos da hídricos do rio São Francisco para execução do PISF e estabelece as condições. Assinada em 22 de setembro de 2005, ele tem validade por 20 anos. Segundo o documento, a vazão firme disponível para bombeamento nos eixos Leste e Norte, a qualquer tempo, é de $26,4 \mathrm{~m}^{3} / \mathrm{s}$, volume que pode ser retirado para consumo humano e dessedentação animal na região e que corresponde à demanda projetada para 2025. Enquanto a demanda real for inferior a $26,4 \mathrm{~m}^{3} / \mathrm{s}$, a ANA autoriza o PISF a atender o uso múltiplo dos recursos hídricos na região receptora (ANA, 2005).

A retirada, no entanto, poderá ser maior em dois casos excepcionais: quando o reservatório de Sobradinho estiver com nível correspondente ao armazenamento de 94\% do volume útil, ou nível correspondente ao volume de espera para controle de cheias. Nesses casos, fica autorizada a captação máxima diária de $114,3 \mathrm{~m}^{3} / \mathrm{s}$ e instantânea de $127 \mathrm{~m}^{3 / \mathrm{s}}$ (ANA, 2005).

Segundo Paulo Varella (informação verbal) ${ }^{6}$, trata-se de um projeto de transposição de volume, e não de vazão. Ou seja, a torneira não estará ligada toda hora. Em determinadas condições, a água será transportada até chegar às bacias de destino.

A repartição das vazões bombeadas do Rio São Francisco entre usuários e os estados beneficiados, assim como as tarifas de cobrança pelo serviço de adução de água bruta serão definidas no Plano de Gestão Anual, que será elaborado pelo Conselho Gestor, por meio da operadora federal. A Codevasf será a responsável pela operacionalização da infraestrutura inicialmente (ANA, 2005).

As operadoras estaduais ficarão encarregadas de operar as infraestruturas hídricas interligadas em seus respectivos estados, distribuir a água bruta, zelar pelo uso eficiente e 
racional da água disponibilizada pelo PISF, manter cadastro dos usuários dos recursos hídricos e apoiar o órgão gestor estadual nos procedimentos de outorga e fiscalização dos usos da água na sua área de atuação, apresentar à operadora federal e à ANA seu plano operativo anual com previsão de demanda de água do PISF, pagar à operadora federal os valores correspondentes, entre outros (BRASIL, 2006).

Varella esclarece que todos os estados terão que pagar pela água que será disponibilizada pelo PISF, "quer usem, quer não usem: pagam pela possibilidade de a qualquer hora querer”. Está prevista a cobrança de um valor mínimo das operadoras estaduais, que deverá ser repassado à operadora federal para que a manutenção dos equipamentos seja mantida.

\subsection{DISTRIBUIÇÃO DE ÁGUA PELO EIXO LESTE DO PISF}

A execução do Eixo Leste, analisado nesse trabalho, foi dividida pelo MI em dois lotes, C e D. O primeiro deles compreende a construção das estruturas contidas entre a Estação de Bombeamento EBV-1 e o Reservatório de Copiti e foi de responsabilidade do Consórcio Techne-Projetec-BRLi. Embora esteja compreendida no trecho acima citado, a Barragem de Areias ficou a cargo do Batalhão de Engenharia de Construção do Exército Brasileiro. O lote D, por sua vez, compreende as estruturas entre o Reservatório Copiti e a Adutora Monteiro, sob responsabilidade do Consórcio Ecoplan-Skill (CONSÓRCIO TECHNE-PROJETETECBRLi, 2012; CONSÓRCIO ECOPLAN-SKILL, 2014).

Em ambos os lotes, o Projeto Executivo foi elaborado no decorrer das obras. Dividido em 12 volumes que somam mais de mil páginas, o Projeto Executivo do Eixo Leste fornece pormenores técnicos, detalha o uso de materiais, apresenta mapas e ilustrações das estruturas usadas, além das adaptações necessárias quanto ao que previa o Projeto Básico, feito pela Fundação de Ciência, Aplicações e Tecnologias Espaciais em 2000 e 2001 . A figura 9 ilustra o traçado do Eixo Leste, seus reservatórios até a calha natural do rio Paraíba, em Monteiro (PB). As figuras 10 e 11 mostram respectivamente o Reservatório de Itaparica, ponto inicial do Eixo Leste, e a Estação de Bombeamento. 
Figura 9 - Traçado do Eixo Leste do Projeto de Integração do Rio São Francisco com as Bacias Hidrográficas do Nordeste Setentrional (PISF)

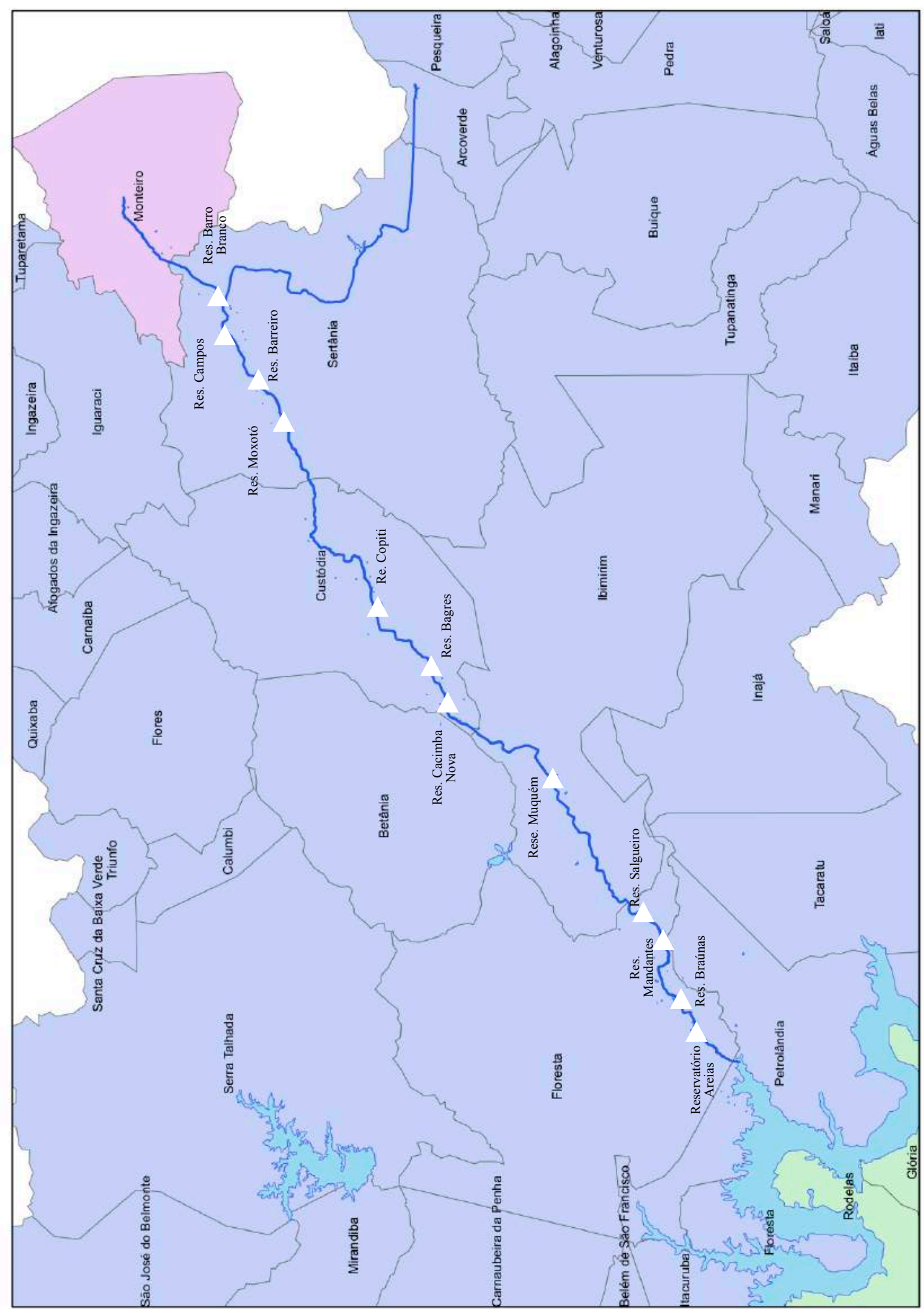

Fonte: Consórcio Concremat-Arcadis Logos, 2017 
Figura 10 - Visão panorâmica da Barragem de Itaparica, município de Floresta, Pernambuco

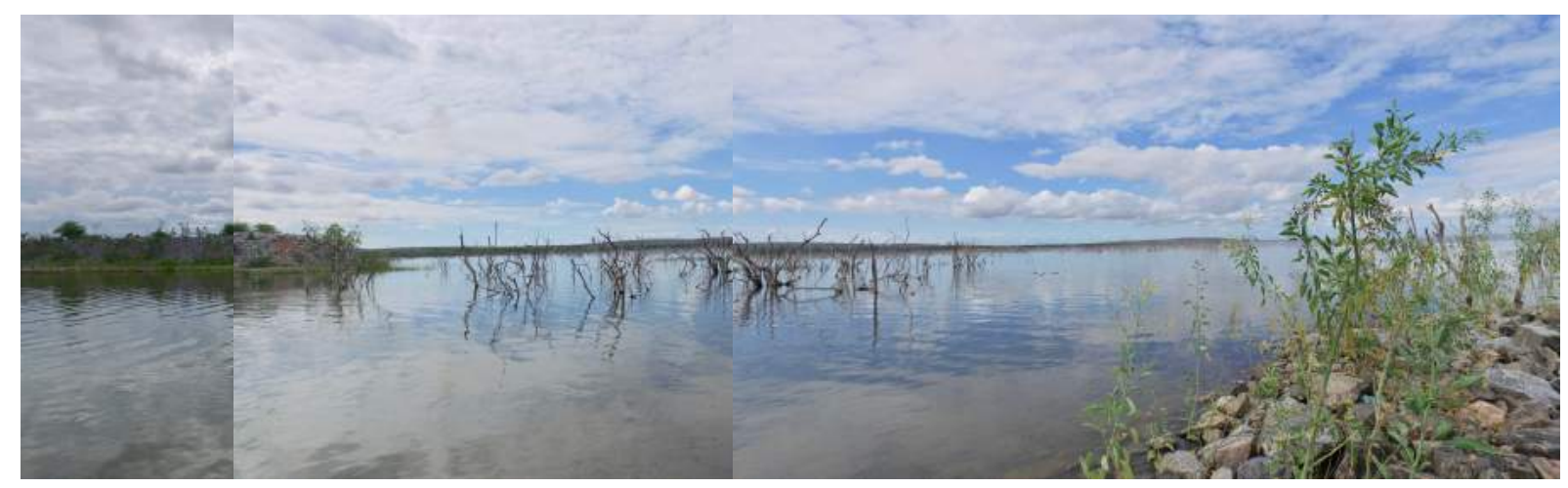

Nádia Pontes, março 2017

Figura 11 - Estação de Bombeamento 1 do Eixo Leste, Pernambuco

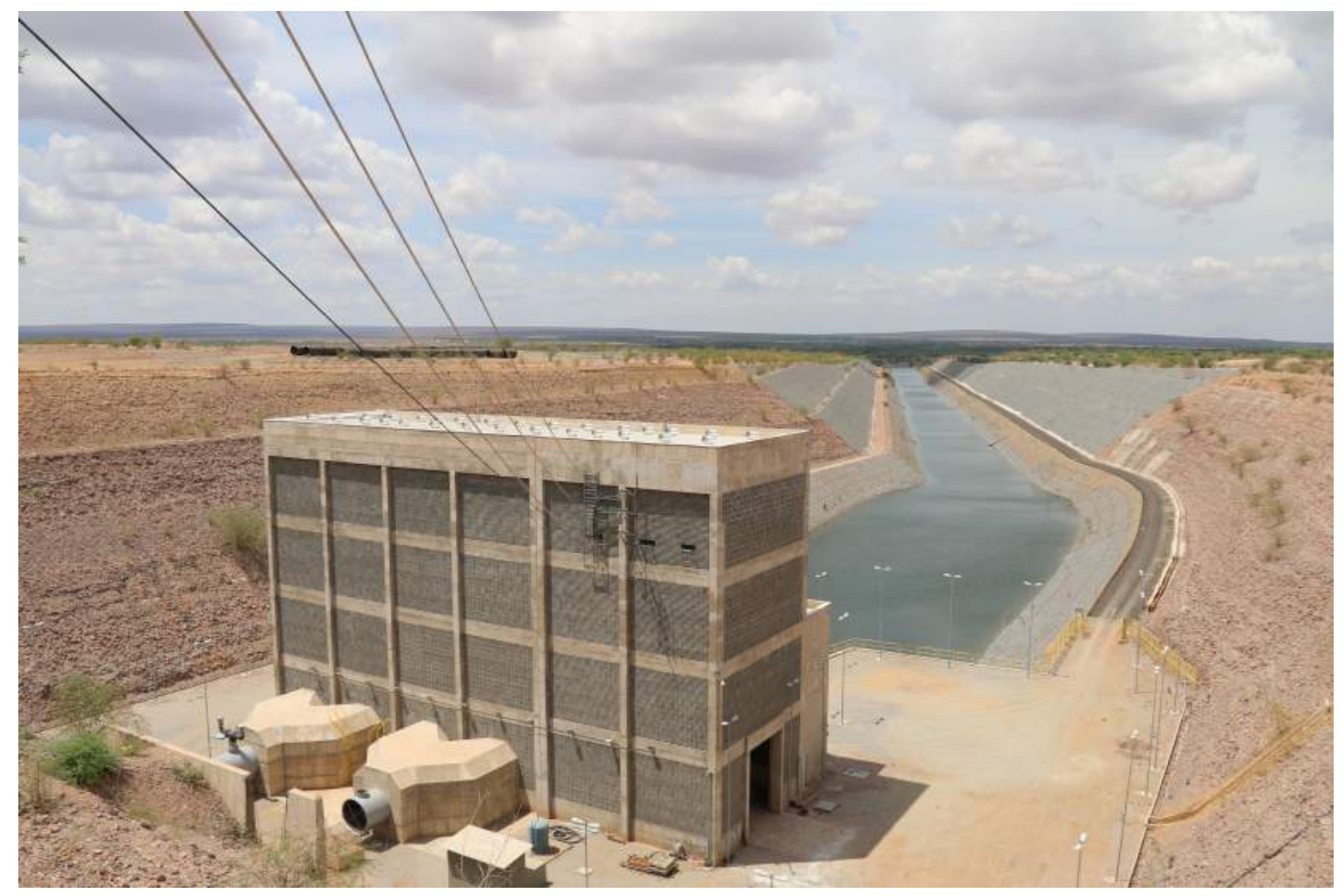

Nádia Pontes, março 2017 
Segundo o Projeto Executivo, adequações foram necessárias após a obtenção de mais informações colhidas pelas prospecções geotécnicas de campo, ensaios de laboratório e levantamentos topográficos (CONSÓRCIO TECHNE-PROJETEC-BRLi, 2012; CONSÓRCIO ECOPLAN-SKILL, 2014).

O traçado dos canais do Eixo Leste foi mantido conforme o previsto no Projeto Básico, decisão técnica possível após os detalhes obtidos com estudos de topografia e geotecnia. Estão contidos no Projeto Executivo informações sobre as chamadas tomadas d'água de uso difuso, objeto de especial atenção dessa pesquisa. Essas estruturas estão previstas em todos os reservatórios/barragens e alguns canais do Eixo Leste e foram planejadas para atender a duas funções: auxiliar no esvaziamento do reservatórios através das tubulações e atender a projetos de abastecimento e/ou irrigação ao longo do sistema adutor (CONSÓRCIO TECHNEPROJETEC-BRLi, 2012).

As tomadas de água para usos difusos são as estruturas planejadas no âmbito do PISF para abastecer as populações rurais e comunidades no semiárido. Elas não foram executadas exatamente como previstas no Projeto Básico, o que era permitido pelo MI. Por outro lado, o Projeto Básico estabeleceu como critério a instalação das tomadas d'água a cada 10 quilômetros de canal adutor (CONSÓRCIO ECOPLAN-SKILL, 2011).

Em todo o Eixo Leste, foram previstos 30 sistemas de abastecimento a partir das tomadas d'água de uso difuso nos canais. Eles devem beneficiar cerca de 31.500 pessoas até 2026 distribuídas em comunidades nos municípios de Floresta, Custódia, Betânia e Sertânia (estado de Pernambuco) e oito comunidades no município de Monteiro, no estado da Paraíba. Dos 30 sistemas previstos, 23 captam água diretamente nos canais adutores do Eixo Leste e sete retiram de barragens, açudes e adutoras (CONSÓRCIO ECOPLAN-SKILL, 2011).

Todos os reservatórios do Lote $\mathrm{C}$ sob a responsabilidade do Consórcio Techne-ProjetecBRLi foram projetados com tomada d'água de fundo, com uma tubulação equipada com válvula dispersora e de uma outra tubulação para o atendimento a projetos de abastecimento e/ou irrigação situados ao longo do sistema adutor. Nos reservatórios de Braúnas, Mandantes, Salgueiro, Cacimba Nova e Bagres as tomadas foram dimensionadas para $2 \mathrm{~m}^{3 / \mathrm{seg}}$ (CONSÓRCIO TECHNE-PROJETEC-BRLi, 2012). 
O Projeto Executivo do Lote C prevê ainda estruturas de derivação nas barragens de Muquém e Copiti, projetadas para derivar vazões mais elevadas a projetos de grande porte. A partir de Muquém, está previsto a derivação de até $10,0 \mathrm{~m}^{3} / \mathrm{seg}$ para o abastecimento do açude Barra do Juá com o objetivo de abastecer o futuro Projeto de Irrigação Serra Negra. Já na barragem Copiti, a estrutura prevista irá transportar até $18,00 \mathrm{~m}^{3} / \mathrm{seg}$ para o açude Poço da Cruz com a finalidade de suprir o Perímetro de Irrigação do Moxotó (CONSÓRCIO TECHNE-PROJETEC-BRLi, 2012).

O Projeto Executivo do Lote D detalha mais o uso previsto das tomadas d'água a partir das barragens. Segundo o documento, elas foram projetadas com o objetivo de atender ao Programa Básico Ambiental, especificamente o PBA 15 - "Programa de Implantação de InfraEstrutura de Abastecimento Público de Água às Populações Localizadas ao Longo dos Canais do PISF” (CONSÓRCIO ECOPLAN-SKILL, 2011).

Na confecção do PBA 15, foram consideradas questões como distância entre as partes habitadas e fontes hídricas, existência de energia para o bombeamento da água. Ambos fatores têm influência direta no preço dos serviços de abastecimento. Portanto, algumas diretrizes técnicas e operacionais foram estabelecidas em busca de soluções de abastecimento apropriadas para a região. Dessa forma, foi priorizado o abastecimento a partir dos reservatórios do PISF para as regiões mais populosas e as menores localizadas ao longo dos canais. Para as comunidades que não se encaixam nessa descrição, o documento afirma que alternativas de abastecimento serão estudadas, sendo que as tomadas de água para uso difuso são apontadas como parte da solução para atender essas populações mais distantes (CONSÓRCIO ECOPLAN-SKILL, 2011).

Ainda no trecho correspondente ao Lote D, foram previstas 21 estruturas com a finalidade de abastecer as comunidades localizadas às margens do sistema, numa faixa de até 10 quilômetros do empreendimento hídrico. No total, 43 comunidades de cinco municípios dos estados de Pernambuco e Paraíba devem ser contempladas (CONSÓRCIO ECOPLANSKILL, 2011; MINISTÉRIO DA INTEGRAÇÃO NACIONAL, 2005).

A retirada da água no trecho será feita a partir de 15 sistemas localizados em canais adutores, quatro em barragens/açudes e dois captando água da adutora Monteiro. A tomada d'água de uso difuso prevista nas margens do sistema adutor é composta por um conjunto 
motor-bomba instalado sobre uma balsa flutuante - presa em ambas as margens por cabos de aço, uma tubulação de recalque e uma casa de comando e controle, como ilustra a figura 12 (CONSÓRCIO ECOPLAN-SKILL, 2011).

O Projeto Executivo do Lote D cita as estruturas que devem ser instaladas conforme detalha o PBA-15: estruturas de captação junto aos canais, constituídos de tomada de água, unidade de bombeamento e estação compacta de tratamento de água; redes de distribuição desde as captações até as localidades rurais a serem atendidas; unidades locais de abastecimento comunitário compostas por caixa de água e chafariz nas localidades não servidas por redes de distribuição domiciliar. Essa última seria a situação da grande maioria das comunidades cadastradas (CONSÓRCIO ECOPLAN-SKILL, 2011).

O reservatório Barro Branco, parte do Lote $\mathrm{D}$, será equipado com uma estrutura específica para derivar 8,0 m3/s para o sistema adutor do Ramal do Agreste. Esse fará o transporte até o reservatório de Ipojuca com o objetivo de abastecer a região do Agreste Pernambucano (CONSÓRCIO ECOPLAN-SKILL, 2011).

Figura 12 - Seção transversal da tomada d'água de uso difuso nos canais do Eixo Leste do PISF

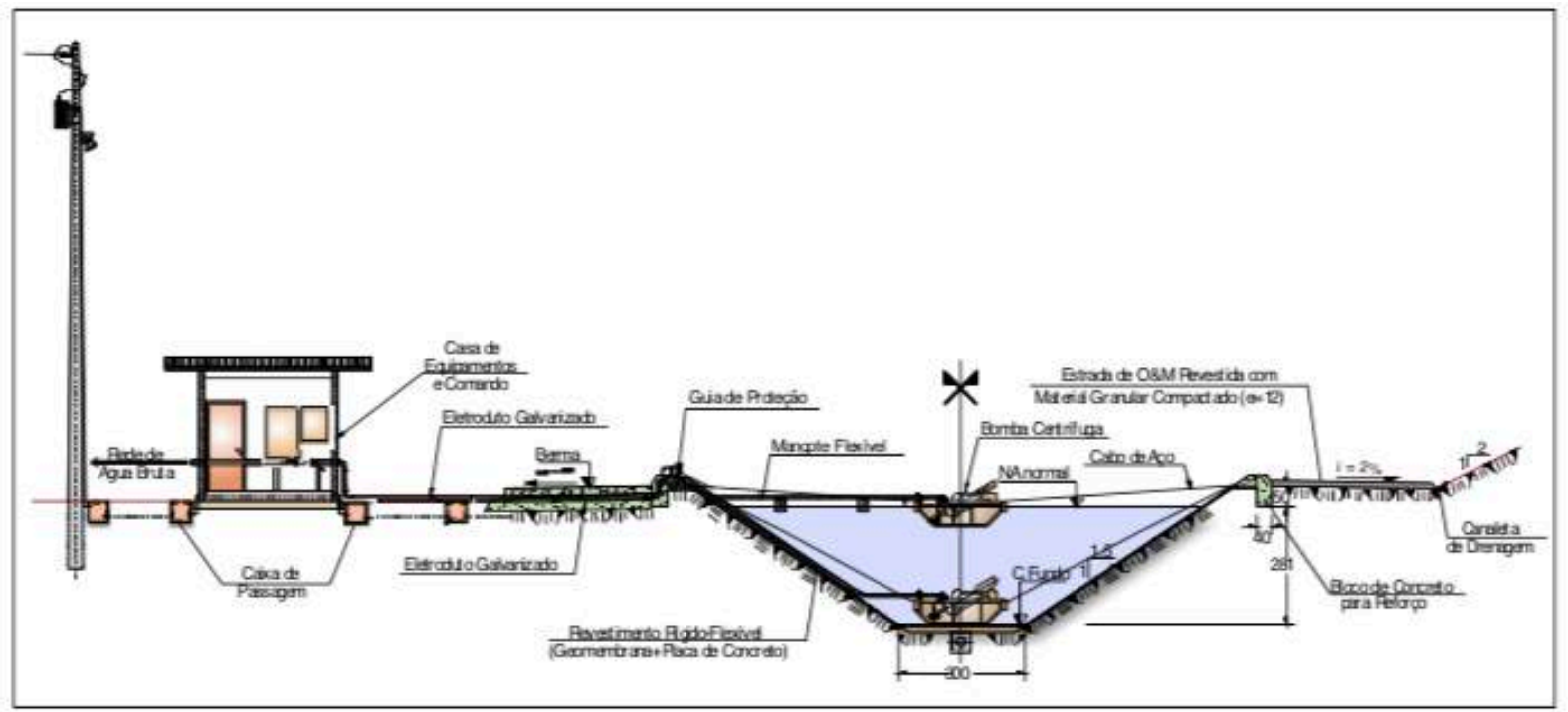

Fonte: Consórcio Ecoplan-Skill, 2011 
Em termos de ajustes legais para a realização dos sistemas paralelos para retirada de água a partir dos canais, o PBA 15 estabeleceu como pré-requisito a instituição de um compromisso formal das administrações locais. Dessa forma, fica sob responsabilidade das prefeituras a implantação dos sistemas de abastecimento de água, fornecer equipe de extensão técnica para atuar nas comunidades que serão beneficiadas a fim de prepará-las para usar o sistema de forma adequada, fazer serviços de manutenção de rotina e reparos nas infraestruturas fora da faixa de domínio das obras da transposição (MINISTÉRIO DA INTEGRAÇÃO NACIONAL, 2005).

Os documentos que compõem o Projeto Executivo do Eixo Leste afirmam que as tomadas d'água trarão melhorias das condições de vida das comunidades rurais posicionadas ao longo dos canais da transposição, que reconhecidamente contam com suprimento hídrico precário. Enquanto oferece segurança hídrica e água de boa qualidade, o sistema das tomadas d'água de uso difuso reduz os riscos sociais, sanitários e econômicos ligados a possíveis retiradas ilegais ou clandestinas dos canais e reservatórios que formam o sistema (CONSÓRCIO ECOPLAN-SKILL, 2011).

\subsection{ATENDIMENTO Às POPULAÇÕES RURAIS DIFUSAS}

Os sistemas de distribuição de água às comunidades situadas na área diretamente afetadas pelo Eixo Leste do PISF, segundo preconiza o PBA 15, foram descritos em projetos executivos de responsabilidade do DNOCS, porém executados pelo Consórcio Projetec/ Engesoft (2014a).

Um acordo assinado entre MI e DNOCS/PE estabeleceu que uma rede de distribuição de água tratada seria implantado apenas em comunidades onde o número de famílias fosse maior que 40, ou 160 moradores, desde que as residências estivessem agrupadas. Para as comunidades com menos de 40 famílias, seria disponibilizado um chafariz como estrutura de reservação e abastecimento de água tratada. Para o Eixo Leste, foi prevista a implantação de 30 sistemas, que seguem um padrão aproximado. Em geral, o sistema é projetado para captar água a partir de uma plataforma flutuante instalada no canal de transposição equipada com uma bomba com motor elétrico; estação elevatória de água bruta; adutora de água bruta; 
estação de tratamento de água; estação elevatória de água tratada; adutora de água tratada (CONSÓRCIO PROJETEC/ENGESOFT, 2014a).

No município de Floresta (PE) encontra-se inserido no Polígono das Secas. Ele é o maior em área dentro da área de influência do Eixo Leste do PISF, cinco sistemas de uso difuso devem ser abastecer 14 comunidades, totalizando 1648 pessoas. Na zona rural do município, onde vivem 32\% da população residente, ou 9312 indivíduos, 5,3\% dos domicílios são abastecidos com rede de distribuição; 4,7\% contam com poços artesianos ou fontes naturais, $90 \%$ são alimentados por outras fontes de água, incluindo caminhões-pipa (CONSÓRCIO PROJETEC/ENGESOFT, 2014a). Nesse caso, pode-se dizer que o Eixo Leste do PISF supriria a necessidade de $17 \%$ da população rural de Floresta.

O município de Betânia (PE), também está localizado no Polígono das Secas, conhecido por sua elevada irregularidade pluviométrica, altas taxas de evaporação superficial. Com 12.003 habitantes, a maior parte da população habita a zona rural (8281 pessoas), o equivalente a 69,1\%. Quanto à infraestrutura existente de abastecimento de água, 43,1\% dos domicílios são atendidos pela rede geral de distribuição; poços e/ou fontes abastecem 29,5\%. Para o restante, $27,5 \%$ dos domicílios, restam outras formas de abastecimento, como caminhões-pipa (CONSÓRCIO PROJETEC/ENGESOFT, 2014e). Em Betânia, o sistema de uso difuso do Eixo Leste do PISF a ser implantado no município beneficiaria 724 pessoas, ou $8,7 \%$ da população rural estimada.

Dos 21.716 habitantes do município de Custódia (PE), 35,9\% estão na zona rural. (12.139 habitantes). Desses, 3,4\% dos domicílios são atendidos pela rede geral de distribuição de água, 53\% contam com poços e/ou fontes e 43,5\% são alimentados por outras formas de abastecimento (CONSÓRCIO PROJETEC/ENGESOFT, 2014f). A estimativa é que os sistemas de uso difuso do Eixo Leste do PISF no município atenderia 5813 pessoas, o equivalente a $48 \%$ da população rural.

Em Sertânia (PE), estima-se uma população total de 33.787, dos quais 45,08\% (15.230) vivam na zona rural. Nessa parte do município, a infraestrutura existente de abastecimento de água é oferecida a 14,62\% dos domicílios atendidos pela rede geral de distribuição, 30,59\% são abastecidos por poços e/ou fontes e 54,79\% precisam recorrer a outras formas de abastecimento (CONSÓRCIO PROJETEC/ENGESOFT, 2015f). Segundo projetos de 
atendimento por meio de sistemas de uso difuso do Eixo Leste do PISF, 5140 moradores seriam beneficiados, o que equivale a $33,7 \%$ da população rural.

Em Monteiro, município do estado da Paraíba, foram contabilizados 30.852 habitantes, dos quais 10.591 habitantes $(34,3 \%)$ estão inseridos na zona rural. Quanto ao abastecimento de água, $0,8 \%$ dos domicílios são atendidos pela rede geral de distribuição, 79,4\% dos abastecem-se por meio de poços e/ou nascentes e 19,7\% são alimentados por outras formas de abastecimento (CONSÓRCIO PROJETEC/ENGESOFT, 2015n). Os sistemas de uso difuso do Eixo Leste do PISF forneceriam água para 8510 moradores da zona rural, o equivalente a $80,3 \%$.

Embora o PBA 15 preveja 30 sistemas para abastecer as comunidades rurais do longo do Eixo Leste (MINISTÉRIO DA INTEGRAÇÃO NACIONAL, 2005), o MI encaminhou 26 projetos de tais sistemas, dentre os quais Básicos e Executivos, perante solicitação para essa pesquisa.

Segundo o MI, a implementação dos sistemas ficou a cargo dos estados. Um termo de compromisso formal foi feito em que o ministério repassa os recursos para entidades estaduais. Em Pernambuco, a Companhia Pernambucana de Saneamento (Compesa) ficou responsável pela implementação dos sistemas em comunidades maiores. Já a Secretaria de Agricultura de Reforma Agrária (SARA) atenderá comunidades rurais menores. No estado da Paraíba, a responsabilidade está a cargo da Secretaria de Recursos Hídricos e Meio Ambiente.

Os Planos de Trabalho celebrados estabeleceram responsabilidades e prazos para implantação, gestão e operação da infraestrutura de água em comunidades rurais ao longo dos canais do Eixo Leste do PISF. Eles obedecem à condicionante 2.1 da Licença de Instalação n 925/20137, que observa a obrigatoriedade da implementação dos programas propostos, como o PBA 15.

Em janeiro de 2016, o Plano de Trabalho acordado entre MI e Compesa previu a instalação de quatro sistemas que contemplam 42 comunidades no estado de Pernambuco. $\mathrm{O}$ prazo inicial venceria após 24 meses, ou janeiro de 2018 (Anexo 1). Porém, em dezembro de 2017, o prazo foi estendido para 48 meses a contar a partir de dezembro de 2015, ou seja, dezembro de 2019.

\footnotetext{
7 Documento disponível em http://www.mi.gov.br/documents/10157/3675235/ LICENCA+DE+INSTALACAO+925+2013.pdf/21145469-5c7c-4135-80b1-dbe5fa6ec84d Acessado em $02 / 06 / 2018$
} 
O mesmo padrão é observado no Plano de Trabalho assinado entre MI e SARA. A partir de janeiro de 2016, o órgão estadual ficou responsável pela implantação da maior parte dos sistemas planejados para Pernambuco, totalizando quinze. Assinado em 2016 com prazo de 24 meses (Anexo 2), o Plano de Trabalho original entre MI e SARA foi adiado para 48 meses a contar a partir de dezembro de 2015 .

Para a implantação dos sistemas de uso difuso destinados a comunidades rurais ao longo do Eixo Leste do PISF na Paraíba foi assinado um Plano de Trabalho entre MI e Secretaria de Infraestrutura Hídrica, dos Recursos Hídricos, do Meio Ambiente e da Ciência e Tecnologia do Estado da Paraíba, em janeiro de 2016. Num prazo de 24 meses, o órgão teria que implementar sete sistemas de uso difuso, como previram os Projetos Executivos (CONSÓRCIO PROJETEC/ENGESOFT, 2015g, 2015h, 2015i, 2015j, 20151, 2015m, 2015n). Por outro lado, o Plano de Trabalho (Anexo 3) estabeleceu a implantação de cinco sistemas, mas que atenderiam ao mesmo número de comunidades, totalizando vinte. Como observado nos outros casos, o Plano de Trabalho foi adiado para 48 meses, com prazo estendido até dezembro de 2019.

A figura 13 mostra a localização das comunidades rurais previstas para serem atendidas pelo PBA 15 (MINISTÉRIO DA INTEGRAÇÃO NACIONAL, 2005). As tabelas 5, 6, 7, 8 e 9 sistematizam as informações referentes aos sistemas de uso difuso previstos nos Projetos Executivos classificando-as a partir do município, número do sistema difuso, comunidades que serão atendidas, número de habitantes, local onde a água será captada, sistema de distribuição de água previsto, órgão responsável pela obra e prazo inicial estabelecido pelo Plano de Trabalho (CONSÓRCIO PROJETEC/ENGESOFT, 2014a, 2014b, 2014c, 2014d, 2014e, 2014f, 2014g, 2014h, 2014i, 2014j, 20141, 2014m, 2014n, 2015a, 2015b, 2015c, 2015d, 2015e, 2015f, 2015g, 2015h, 2015i, 2015j, 20151, 2015m, 2015n). 
Figura 13 - Mapa das comunidades atendidas pelo Plano Ambiental 15 ao longo do Eixo Leste do PISF

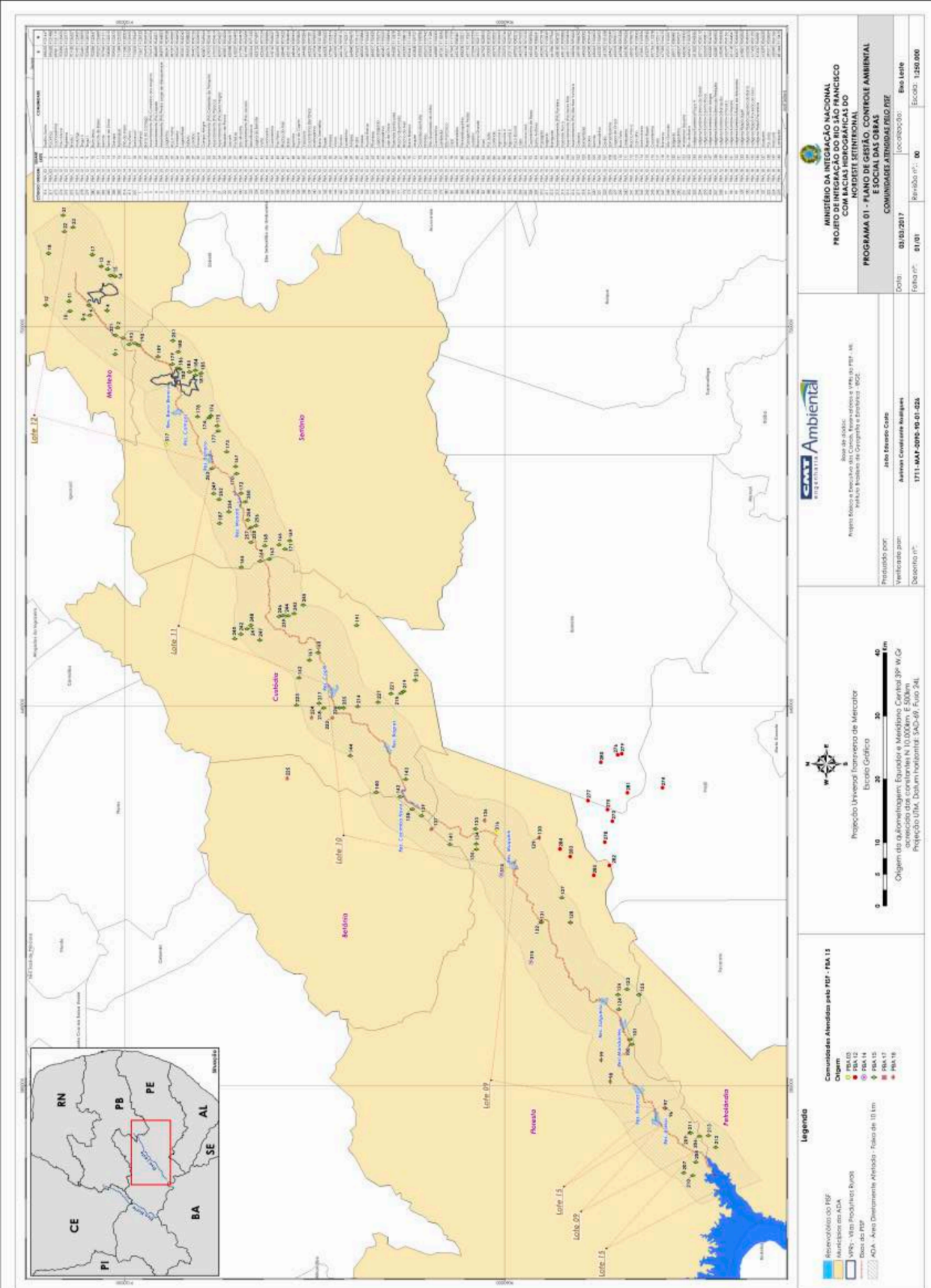

Fonte: Ministério da Integração Nacional, 2017 
Tabela 5 - Sistemas de uso difuso do Eixo Leste do PISF previstos para o município de Floresta (PE)

\begin{tabular}{|c|c|c|c|c|c|c|}
\hline $\begin{array}{l}\text { Nome do } \\
\text { sistema }\end{array}$ & $\begin{array}{l}\text { Comunidades } \\
\text { atendidas }\end{array}$ & $\begin{array}{l}\mathrm{N}^{\circ} \text { de } \\
\text { habitantes }\end{array}$ & Captação & $\begin{array}{l}\text { Distribuição/ } \\
\text { Chafariz }\end{array}$ & Atribuição & $\begin{array}{l}\text { Prazo } \\
\text { Original }\end{array}$ \\
\hline \multirow[t]{8}{*}{ Sistema 1} & Agrovila 4 & 304 & \multirow{8}{*}{$\begin{array}{l}\text { Canal da } \\
\text { transposição }\end{array}$} & Distribuição & \multirow{8}{*}{$\begin{array}{l}\text { Companhia } \\
\text { Pernambucana } \\
\text { de Saneamento } \\
\text { (Compesa) }\end{array}$} & \multirow{8}{*}{$\begin{array}{l}\text { Janeiro } \\
2018\end{array}$} \\
\hline & Agrovila 5 & 624 & & Distribuição & & \\
\hline & Agrovila 6 & 240 & & Distribuição & & \\
\hline & Pai João & 20 & & Chafariz & & \\
\hline & Juazeiro & 12 & & Chafariz & & \\
\hline & Catende & 28 & & Chafariz & & \\
\hline & Sítio Mari & 20 & & Chafariz & & \\
\hline & Riacho Grande & 16 & & Chafariz & & \\
\hline \multirow[t]{4}{*}{ Sistema 2} & Assentamento & 200 & \multirow{4}{*}{$\begin{array}{l}\text { Barragem } \\
\text { Areias } \\
\text { (sistema } \\
\text { plataforma } \\
\text { flutuante) }\end{array}$} & Distribuição & \multirow{4}{*}{$\begin{array}{l}\text { Secretaria de } \\
\text { Agricultura e } \\
\text { Reforma } \\
\text { Agrária }\end{array}$} & \multirow{4}{*}{$\begin{array}{l}\text { Janeiro } \\
2018\end{array}$} \\
\hline & $\begin{array}{l}\text { Curralinho dos } \\
\text { Angicos }\end{array}$ & & & & & \\
\hline & Barra do & 16 & & Chafariz & & \\
\hline & Córrego & & & & & \\
\hline \multirow[t]{3}{*}{ Sistema 4} & Assentamento & 48 & \multirow{3}{*}{$\begin{array}{l}\text { Canal da } \\
\text { transposição }\end{array}$} & Chafariz & \multirow{3}{*}{$\begin{array}{l}\text { Secretaria de } \\
\text { Agricultura e } \\
\text { Reforma } \\
\text { Agrária }\end{array}$} & \multirow{3}{*}{$\begin{array}{l}\text { Janeiro } \\
2018\end{array}$} \\
\hline & Lajedo & & & & & \\
\hline & Pedro Jorge & 48 & & Chafariz & & \\
\hline \multirow[t]{3}{*}{ Sistema 5} & Lagoinha & 28 & \multirow{3}{*}{$\begin{array}{l}\text { Canal da } \\
\text { transposição }\end{array}$} & Chafariz & \multirow{3}{*}{$\begin{array}{l}\text { Secretaria de } \\
\text { Agricultura e } \\
\text { Reforma } \\
\text { Agrária }\end{array}$} & \multirow{3}{*}{$\begin{array}{l}\text { Janeiro } \\
2018\end{array}$} \\
\hline & Roça Velha & 44 & & & & \\
\hline & & & & & & \\
\hline
\end{tabular}

Fonte: CONSÓRCIO PROJETEC/ENGESOFT (2014a, 2014b, 2014c, 2014d). 
Tabela 6 - Sistemas de uso difuso do Eixo Leste do PISF previstos para o município de Betânia (PE)

\begin{tabular}{|c|c|c|c|c|c|c|}
\hline $\begin{array}{l}\text { Nome do } \\
\text { sistema }\end{array}$ & $\begin{array}{l}\text { Comunidades } \\
\text { atendidas }\end{array}$ & $\begin{array}{c}\mathrm{N}^{\circ} \text { de } \\
\text { habitantes }\end{array}$ & Captação & $\begin{array}{l}\text { Distribuição/ } \\
\text { Chafariz }\end{array}$ & Atribuição & Prazo \\
\hline \multirow[t]{6}{*}{ Sistema 9} & Serra Branca & 176 & $\begin{array}{l}\text { Canal da } \\
\text { transposição }\end{array}$ & Chafariz & \multirow{6}{*}{$\begin{array}{l}\text { Secretaria de } \\
\text { Agricultura e } \\
\text { Reforma } \\
\text { Agrária }\end{array}$} & \multirow[t]{6}{*}{$\begin{array}{l}\text { Janeiro } \\
2018\end{array}$} \\
\hline & Cacimbinha & 128 & & Chafariz & & \\
\hline & $\begin{array}{l}\text { Lagoa do } \\
\text { Serrote }\end{array}$ & 36 & & Chafariz & & \\
\hline & Volta & 76 & & Chafariz & & \\
\hline & Pau Ferro & 108 & & Chafariz & & \\
\hline & Cachoeira & 200 & & Chafariz & & \\
\hline
\end{tabular}

Fonte: CONSÓRCIO PROJETEC/ENGESOFT (2014e)

Tabela 7 - Sistemas de uso difuso do Eixo Leste do PISF previstos para o município de Custódia (PE)

\begin{tabular}{|c|c|c|c|c|c|c|}
\hline $\begin{array}{l}\text { Nome do } \\
\text { sistema }\end{array}$ & $\begin{array}{l}\text { Comunidades } \\
\text { atendidas }\end{array}$ & $\begin{array}{c}\mathrm{N}^{\circ} \text { de } \\
\text { habitantes }\end{array}$ & Captação & $\begin{array}{l}\text { Distribuição/ } \\
\text { Chafariz }\end{array}$ & Atribuição & Prazo \\
\hline $\begin{array}{l}\text { Sistema } \\
11\end{array}$ & Riacho do Mel & 80 & $\begin{array}{l}\text { Canal da } \\
\text { transposição }\end{array}$ & Chafariz & $\begin{array}{l}\text { Secretaria de } \\
\text { Agricultura e } \\
\text { Reforma } \\
\text { Agrária }\end{array}$ & $\begin{array}{l}\text { Janeiro } \\
2018\end{array}$ \\
\hline $\begin{array}{l}\text { Sistema } \\
12\end{array}$ & Baixa & 64 & $\begin{array}{l}\text { Canal da } \\
\text { transposição }\end{array}$ & Chafariz & $\begin{array}{l}\text { Secretaria de } \\
\text { Agricultura e } \\
\text { Reforma } \\
\text { Agrária }\end{array}$ & $\begin{array}{l}\text { Janeiro } \\
2018\end{array}$ \\
\hline \multirow{10}{*}{$\begin{array}{l}\text { Sistema } \\
13\end{array}$} & Barriguda & 144 & \multirow{10}{*}{$\begin{array}{l}\text { Canal da } \\
\text { transposição }\end{array}$} & Chafariz & \multirow{10}{*}{$\begin{array}{l}\text { Companhia } \\
\text { Pernambucana } \\
\text { de Saneamento } \\
\text { (Compesa) }\end{array}$} & \multirow{10}{*}{$\begin{array}{l}\text { Janeiro } \\
2018\end{array}$} \\
\hline & Caiçara & 504 & & Distribuição & & \\
\hline & Cavaco/Joá & 112 & & Chafariz & & \\
\hline & Lajes & 8 & & Chafariz & & \\
\hline & Papagio & 112 & & Chafariz & & \\
\hline & Poço Escuro & 8 & & Chafariz & & \\
\hline & Salgado & 136 & & Distribuição & & \\
\hline & Samambaia & 1860 & & Distribuição & & \\
\hline & Ass.Porteira & 168 & & Distribuição & & \\
\hline & Ass.SantaRita & 328 & & Chaf/ Distr & & \\
\hline
\end{tabular}


(continuação)

\begin{tabular}{|c|c|c|c|c|c|c|}
\hline $\begin{array}{l}\text { Nome do } \\
\text { sistema }\end{array}$ & $\begin{array}{l}\text { Comunidades } \\
\text { atendidas }\end{array}$ & $\begin{array}{c}\mathrm{N}^{\circ} \text { de } \\
\text { habitantes }\end{array}$ & Captação & $\begin{array}{l}\text { Distribuiç̧ão/ } \\
\text { Chafariz }\end{array}$ & Atribuição & Prazo \\
\hline \multirow[t]{4}{*}{$\begin{array}{l}\text { Sistema } \\
13\end{array}$} & $\begin{array}{l}\text { Cacimbinha de } \\
\text { Baixo }\end{array}$ & 48 & \multirow[t]{4}{*}{$\begin{array}{l}\text { Canal da } \\
\text { transposição }\end{array}$} & Chafariz & \multirow{4}{*}{$\begin{array}{l}\text { Companhia } \\
\text { Pernambucana } \\
\text { de Saneamento } \\
\text { (Compesa) }\end{array}$} & \multirow[t]{4}{*}{$\begin{array}{l}\text { Janeiro } \\
2018\end{array}$} \\
\hline & Fazenda Nova & 252 & & Distribuição & & \\
\hline & $\begin{array}{l}\text { Ass. São Boa } \\
\text { Ventura }\end{array}$ & 484 & & Distribuição & & \\
\hline & Santo Antônio & 72 & & Chafariz & & \\
\hline $\begin{array}{l}\text { Sistema } \\
16\end{array}$ & Jaramantaia & 149 & Poço Tubular & Chafariz & $\begin{array}{l}\text { Secretaria de } \\
\text { Agricultura e } \\
\text { Reforma } \\
\text { Agrária }\end{array}$ & $\begin{array}{l}\text { Janeiro } \\
2018\end{array}$ \\
\hline \multirow{10}{*}{$\begin{array}{l}\text { Sistema } \\
18\end{array}$} & Boa VIsta & 88 & \multirow{10}{*}{$\begin{array}{l}\text { Canal da } \\
\text { transposição }\end{array}$} & Chafariz & \multirow{10}{*}{$\begin{array}{l}\text { Companhia } \\
\text { Pernambucana } \\
\text { de Saneamento } \\
\text { (Compesa) }\end{array}$} & \multirow{10}{*}{$\begin{array}{l}\text { Janeirc } \\
2018\end{array}$} \\
\hline & Carvalho & 600 & & Distribuição & & \\
\hline & Cedro & 28 & & Chafariz & & \\
\hline & Fazendinha & 28 & & Chafariz & & \\
\hline & Lagoa Onça & 180 & & Chafariz & & \\
\hline & Riacho Novo & 144 & & Chafariz & & \\
\hline & Samabainha & 60 & & Chafariz & & \\
\hline & Serrote & 16 & & Chafariz & & \\
\hline & Soares & 12 & & Chafariz & & \\
\hline & Umbuzeiro & 128 & & Chafariz & & \\
\hline
\end{tabular}

Fonte: CONSÓRCIO PROJETEC/ENGESOFT (2014f, 2014g, 2014i, 2015a). 
Tabela 8 - Sistemas de uso difuso do Eixo Leste do PISF previstos para o município de Sertânia (PE)

\begin{tabular}{|c|c|c|c|c|c|c|}
\hline $\begin{array}{l}\text { Nome do } \\
\text { sistema }\end{array}$ & $\begin{array}{l}\text { Comunidades } \\
\text { atendidas }\end{array}$ & $\begin{array}{c}\mathrm{N}^{\circ} \text { de } \\
\text { habitantes }\end{array}$ & Captação & $\begin{array}{l}\text { Distribuição/ } \\
\text { Chafariz }\end{array}$ & Atribuição & Prazo \\
\hline \multirow{5}{*}{$\begin{array}{l}\text { Sistema } \\
20\end{array}$} & Ameixa & 72 & \multirow{5}{*}{$\begin{array}{l}\text { Canal da } \\
\text { transposição }\end{array}$} & Chafariz & \multirow{5}{*}{$\begin{array}{l}\text { Secretaria de } \\
\text { Agricultura e } \\
\text { Reforma } \\
\text { Agrária }\end{array}$} & \multirow{5}{*}{$\begin{array}{l}\text { Janeiro } \\
2018\end{array}$} \\
\hline & Barro & 440 & & Distribuição & & \\
\hline & Vermelho & & & & & \\
\hline & Cacimbinha & 24 & & Chafariz & & \\
\hline & Malhadinha & 40 & & Chafariz & & \\
\hline \multirow{3}{*}{$\begin{array}{l}\text { Sistema } \\
21\end{array}$} & Favela & 168 & \multirow{3}{*}{$\begin{array}{l}\text { Canal da } \\
\text { transposição }\end{array}$} & Distribuição & \multirow{3}{*}{$\begin{array}{l}\text { Secretaria de } \\
\text { Agricultura e } \\
\text { Reforma } \\
\text { Agrária }\end{array}$} & \multirow{3}{*}{$\begin{array}{l}\text { Janeiro } \\
2018\end{array}$} \\
\hline & Viana & 108 & & Chafariz & & \\
\hline & Frade & 68 & & Chafariz & & \\
\hline \multirow{10}{*}{$\begin{array}{l}\text { Sistema } \\
22\end{array}$} & Barreiros & 60 & \multirow{10}{*}{$\begin{array}{l}\text { Canal da } \\
\text { transposição }\end{array}$} & Chafariz & \multirow{10}{*}{$\begin{array}{l}\text { Companhia } \\
\text { Pernambucana } \\
\text { de Saneamento } \\
\text { (Compesa) }\end{array}$} & \multirow{10}{*}{$\begin{array}{l}\text { Janeiro } \\
2018\end{array}$} \\
\hline & Cacimbinha & 120 & & Chafariz & & \\
\hline & Maia & 52 & & Chafariz & & \\
\hline & Rio da Barra & 680 & & Distribuição & & \\
\hline & Salgadinho & 224 & & Distribuição & & \\
\hline & Salgado & 112 & & Chafariz & & \\
\hline & Santa Maria & 36 & & Chafariz & & \\
\hline & São Gonçalo & 108 & & Chafariz & & \\
\hline & $\begin{array}{l}\text { Waldemar } \\
\text { Siqueira }\end{array}$ & 600 & & Distribuição & & \\
\hline & Xique-xique & 12 & & Chafariz & & \\
\hline \multirow{4}{*}{$\begin{array}{l}\text { Sistema } \\
23\end{array}$} & Ameixa & 140 & \multirow{4}{*}{$\begin{array}{l}\text { Barragem de } \\
\text { Moxotó }\end{array}$} & Chafariz & \multirow{4}{*}{$\begin{array}{l}\text { Secretaria de } \\
\text { Agricultura e } \\
\text { Reforma } \\
\text { Agrária }\end{array}$} & \multirow{4}{*}{$\begin{array}{l}\text { Janeiro } \\
2018\end{array}$} \\
\hline & Brabo & 160 & & Chafariz & & \\
\hline & Ipueirinha & 20 & & Chafariz & & \\
\hline & Maxixe & 140 & & & & \\
\hline \multirow{5}{*}{$\begin{array}{l}\text { Sistema } \\
24\end{array}$} & Laje da Onça & 180 & \multirow{5}{*}{$\begin{array}{l}\text { Canal da } \\
\text { transposição }\end{array}$} & Chafariz & \multirow{5}{*}{$\begin{array}{l}\text { Secretaria de } \\
\text { Agricultura e } \\
\text { Reforma } \\
\text { Agrária }\end{array}$} & \multirow{5}{*}{$\begin{array}{l}\text { Janeiro } \\
2018\end{array}$} \\
\hline & Açude Barras & 28 & & Chafariz & & \\
\hline & Lagoa Salgada & 88 & & Chafariz & & \\
\hline & Malhadinha & 140 & & Chafariz & & \\
\hline & Pitombas & 64 & & Chafariz & & \\
\hline
\end{tabular}

(continua) 
(continuação)

\begin{tabular}{|c|c|c|c|c|c|c|}
\hline $\begin{array}{l}\text { Nome do } \\
\text { sistema }\end{array}$ & $\begin{array}{l}\text { Comunidades } \\
\text { atendidas }\end{array}$ & $\begin{array}{c}\mathrm{N}^{\circ} \text { de } \\
\text { habitantes }\end{array}$ & Captação & $\begin{array}{l}\text { Distribuição/ } \\
\text { Chafariz }\end{array}$ & Atribuição & Prazo \\
\hline \multirow[t]{4}{*}{$\begin{array}{l}\text { Sistema } \\
25\end{array}$} & $\begin{array}{l}\text { Cacimba da } \\
\text { Mata }\end{array}$ & 28 & $\begin{array}{l}\text { Canal da } \\
\text { transposição }\end{array}$ & Chafariz & \multirow{4}{*}{$\begin{array}{l}\text { Secretaria de } \\
\text { Agricultura e } \\
\text { Reforma } \\
\text { Agrária }\end{array}$} & \multirow[t]{4}{*}{$\begin{array}{l}\text { Janeiro } \\
2018\end{array}$} \\
\hline & Cacimbinha & 120 & & Chafariz & & \\
\hline & $\begin{array}{l}\text { Fazenda Santa } \\
\text { Luzia }\end{array}$ & 8 & & Chafariz & & \\
\hline & Juqueri & 28 & & Chafariz & & \\
\hline \multirow{3}{*}{$\begin{array}{l}\text { Sistema } \\
26\end{array}$} & Cipó & 236 & \multirow{3}{*}{$\begin{array}{l}\text { Canal da } \\
\text { transposição }\end{array}$} & Chafariz & \multirow{3}{*}{$\begin{array}{l}\text { Secretaria de } \\
\text { Agricultura e } \\
\text { Reforma } \\
\text { Agrária }\end{array}$} & \multirow{3}{*}{$\begin{array}{l}\text { Janeiro } \\
2018\end{array}$} \\
\hline & Lambedor & 24 & & Chafariz & & \\
\hline & São Francisco & 104 & & Chafariz & & \\
\hline $\begin{array}{l}\text { Sistema } \\
27\end{array}$ & $\begin{array}{l}\text { Passagem da } \\
\text { Pedra }\end{array}$ & 20 & Poço tubular & & $\begin{array}{l}\text { Secretaria de } \\
\text { Agricultura e } \\
\text { Reforma } \\
\text { Agrária }\end{array}$ & $\begin{array}{l}\text { Janeiro } \\
2018\end{array}$ \\
\hline $\begin{array}{l}\text { Sistema } \\
38\end{array}$ & $\begin{array}{l}\text { Pernambuquin } \\
\text { ho }\end{array}$ & 688 & $\begin{array}{l}\text { Poço tubular } \\
\text { (distancia do } \\
\text { canal) }\end{array}$ & & $\begin{array}{l}\text { Secretaria de } \\
\text { Agricultura e } \\
\text { Reforma } \\
\text { Agrária }\end{array}$ & $\begin{array}{l}\text { Janeiro } \\
2018\end{array}$ \\
\hline
\end{tabular}

Fonte: CONSÓRCIO PROJETEC/ENGESOF (2014j, 2014l, 2014m, 2014n, 2015b, 2015c, 2015d, 2015e, 2015f). 
Tabela 9 - Sistemas de uso difuso do Eixo Leste do PISF previstos para o município de Monteiro (PB)

\begin{tabular}{|c|c|c|c|c|c|c|}
\hline $\begin{array}{l}\text { Nome do } \\
\text { sistema }\end{array}$ & $\begin{array}{l}\text { Comunidades } \\
\text { atendidas }\end{array}$ & $\begin{array}{c}\mathrm{N}^{\circ} \text { de } \\
\text { habitantes }\end{array}$ & Captação & $\begin{array}{l}\text { Distribuição/ } \\
\text { Chafariz }\end{array}$ & Atribuição & Prazo \\
\hline \multirow{4}{*}{$\begin{array}{l}\text { Sistema } \\
28\end{array}$} & Pau D'Arco & 144 & \multirow{4}{*}{$\begin{array}{l}\text { Canal da } \\
\text { transposição }\end{array}$} & Chafariz & \multirow{4}{*}{$\begin{array}{l}\text { Secretaria } \\
\text { Estado de } \\
\text { Infraestrutura } \\
\text { Hídrica }\end{array}$} & \multirow[t]{4}{*}{ Janeiro 2018} \\
\hline & Rigideira & 168 & & Distribuição & & \\
\hline & Bredo 1 & 1008 & & Distribuição & & \\
\hline & Mulungu & 1200 & & Distribuição & & \\
\hline \multirow{3}{*}{$\begin{array}{l}\text { Sistema } \\
29\end{array}$} & Bom Jesus & 672 & \multirow{3}{*}{$\begin{array}{l}\text { Canal da } \\
\text { transposição }\end{array}$} & Distribuição & \multirow{3}{*}{$\begin{array}{l}\text { Secretaria } \\
\text { Estado de } \\
\text { Infraestrutura } \\
\text { Hídrica }\end{array}$} & \multirow[t]{3}{*}{ Janeiro 2018} \\
\hline & Tingui 1 & 532 & & Distribuição & & \\
\hline & Tingui 2 & 172 & & Distribuição & & \\
\hline \multirow{6}{*}{$\begin{array}{l}\text { Sistema } \\
30\end{array}$} & Garapa & 352 & \multirow[t]{6}{*}{ Rio Paraíba } & Chafariz & \multirow{6}{*}{$\begin{array}{l}\text { Secretaria } \\
\text { Estado de } \\
\text { Infraestrutura } \\
\text { Hídrica }\end{array}$} & \multirow[t]{6}{*}{ Janeiro 2018} \\
\hline & Serrote & 160 & & Distribuição & & \\
\hline & $\begin{array}{l}\text { Serrote de } \\
\text { Baixo }\end{array}$ & 148 & & Chafariz & & \\
\hline & $\begin{array}{l}\text { Serrote de } \\
\text { Cima }\end{array}$ & 208 & & Distribuição & & \\
\hline & Sítio do Meio & 668 & & Distribuição & & \\
\hline & Tamanduá & 600 & & Distribuição & & \\
\hline \multirow{4}{*}{$\begin{array}{l}\text { Sistema } \\
31\end{array}$} & Santana 1 & 884 & \multirow{4}{*}{$\begin{array}{l}\text { Canal da } \\
\text { transposição }\end{array}$} & Distribuição & \multirow{4}{*}{$\begin{array}{l}\text { Secretaria } \\
\text { Estado de } \\
\text { Infraestrutura } \\
\text { Hídrica }\end{array}$} & \multirow[t]{4}{*}{ Janeiro 2018} \\
\hline & Santana 2 & 612 & & Distribuição & & \\
\hline & Malhadinha & 16 & & Chafariz & & \\
\hline & Pau Ferro & 500 & & Distribuição & & \\
\hline $\begin{array}{l}\text { Sistema } \\
35\end{array}$ & Espírito Santo & 68 & Poço tubular & & $\begin{array}{l}\text { Secretaria } \\
\text { Estado de } \\
\text { Infraestrutura } \\
\text { Hídrica }\end{array}$ & Janeiro 2018 \\
\hline $\begin{array}{l}\text { Sistema } \\
36\end{array}$ & Pocinhos & 182 & Poço tubular & & $\begin{array}{l}\text { Secretaria } \\
\text { Estado de } \\
\text { Infraestrutura } \\
\text { Hídrica }\end{array}$ & Janeiro 2018 \\
\hline $\begin{array}{l}\text { Sistema } \\
37\end{array}$ & Cachoeirinha & 216 & Poço tubular & & $\begin{array}{l}\text { Secretaria } \\
\text { Estado de } \\
\text { Infraestrutura } \\
\text { Hídrica }\end{array}$ & Janeiro 2018 \\
\hline
\end{tabular}

Fonte: CONSÓRCIO PROJETEC/ENGESOFT (2015g, 2015h, 2015i, 2015j, 20151, 2015m, 2015n). 


\section{OBSERVAÇÕES DA PESQUISA DE CAMPO}

As duas visitas de campo, realizadas em março de 2017 e março de 2018, foram fundamentais para a compreensão do funcionamento do Projeto de Integração do Rio São Francisco com as Bacias do Nordeste Setentrional, PISF. Dada a grandiosidade da obra, a abrangência espacial do Eixo Leste pelos estados de Pernambuco e Paraíba, a análise da interligação dos seus canais artificiais e reservatórios com as bacias hidrográficas, assim como a distribuição da água às populações rurais difusas, mostrou-se uma tarefa não-trivial.

O objetivo era conhecer em detalhes as estruturas do Eixo Leste, entender a engenharia do projeto, entrevistar representantes dos municípios de Floresta (PE) e Monteiro (PB), onde o percurso dos canais artificiais começa e termina respectivamente. Parte importante do trabalho de campo era também a visita ao açude Epitácio Pessoa, comumente chamado de Boqueirão, em Campina Grande, o último reservatório a receber as águas do PISF por meio da calha natural do rio Paraíba. Por determinação do Ministério da Integração Nacional, o percurso de 217 quilômetros dos canais da transposição foi feito na companhia de um funcionário do Consórcio Concremat-Arcadis Logos, gerenciadora das obras do PISF.

É importante salientar que essa pesquisa de campo foi conduzida num momento favorável e histórico, já que transcorreu no período de conclusão das principais obras de engenharia do Eixo Leste, seguido pelo enchimento dos reservatórios e transferência de água para o estado da Paraíba, o que se iniciou em março de 2017. Já a segunda visita de campo se deu um ano após o início das operações. Muitos dos trabalhos que se dedicaram ao tema foram publicados previamente, durante a discussão do PISF ou andamento das obras. A presente análise, portanto, é uma das primeiras feitas com a possibilidade de se comparar documentos que detalhavam seu planejamento com as observações feitas em campo após a finalização do Eixo Leste e de avaliar o seu primeiro ano de operação.

A primeira visita de campo, em março de 2017, ocorreu concomitantemente à chegada da água no estado da Paraíba. A ocasião contou com uma inauguração oficial com presença do presidente da República, Michel Temer. Paralelamente ao evento, anunciado pelo governo federal como se o recurso natural já estivesse sendo distribuído aos moradores do semiárido ${ }^{8}$, a mesma região atravessava, desde 2012, uma seca cuja intensidade e impacto não eram

\footnotetext{
8 Informação disponível: http://www.dw.com/pt-br/à-margem-do-milagre-do-são-francisco/a-38047384
} 
observados há várias décadas. Marengo, Cunha e Alves (2016) relataram significativas perdas agrícolas, com danos consideráveis principalmente para pequenos produtores, desestruturação de grandes áreas de terras agrícolas, afetando centenas de cidades e vilas em toda a região.

\subsection{OPERAÇÃO DE EMERGÊNCIA PARA ENCHIMENTO DO RESERVATÓRIO EPITÁCIO PESSOA, PARAÍBA}

Ainda em março de 2017, o reservatório de Epitácio Pessoa, e ponto final da água transportada pelo Eixo Leste, registrava um dos seus níveis mais baixos, como ilustram o gráfico 1 e as figuras 14 e 15. O sistema de monitoramento da Agência Executiva de Gestão das Águas (AESA) do governo da Paraíba apontava que o reservatório estava com 3\% de sua capacidade.

O açude foi construído pelo Departamento Nacional de Obras Contra as Secas quando os cinco açudes em operação até então já não eram suficientes para atender à crescente demanda em Campina Grande. Com obras iniciadas em 1951, foi inaugurado em 1957 para perenizar o rio Paraíba, abastecer Campina Grande e gerar energia elétrica, sendo que essa última meta nunca foi alcançada (RANGEL JUNIOR; SOUSA, 2014; BRITO, 2013).

Gráfico 1 - Queda no nível do reservatório Epitácio Pessoa de 2008 a 2018

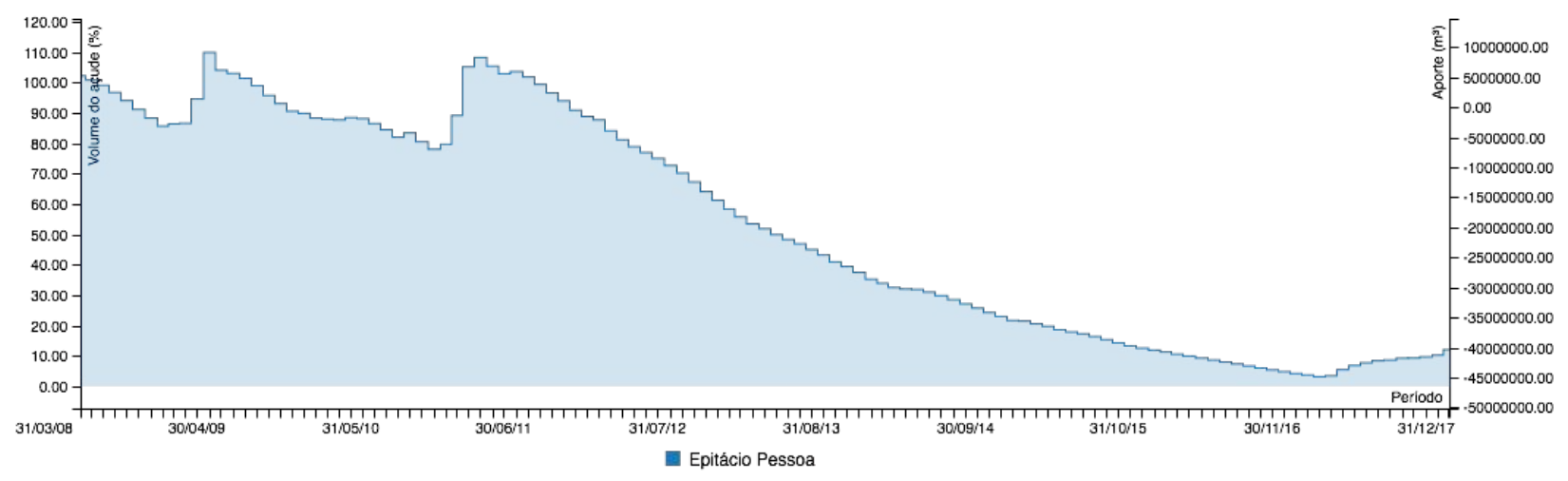

Fonte: AESA, 2018 
Figura 14 - Baixo nível de água no Reservatório Epitácio Pessoa (Boqueirão), Paraíba, em decorrência do ciclo de seca iniciado em 2012

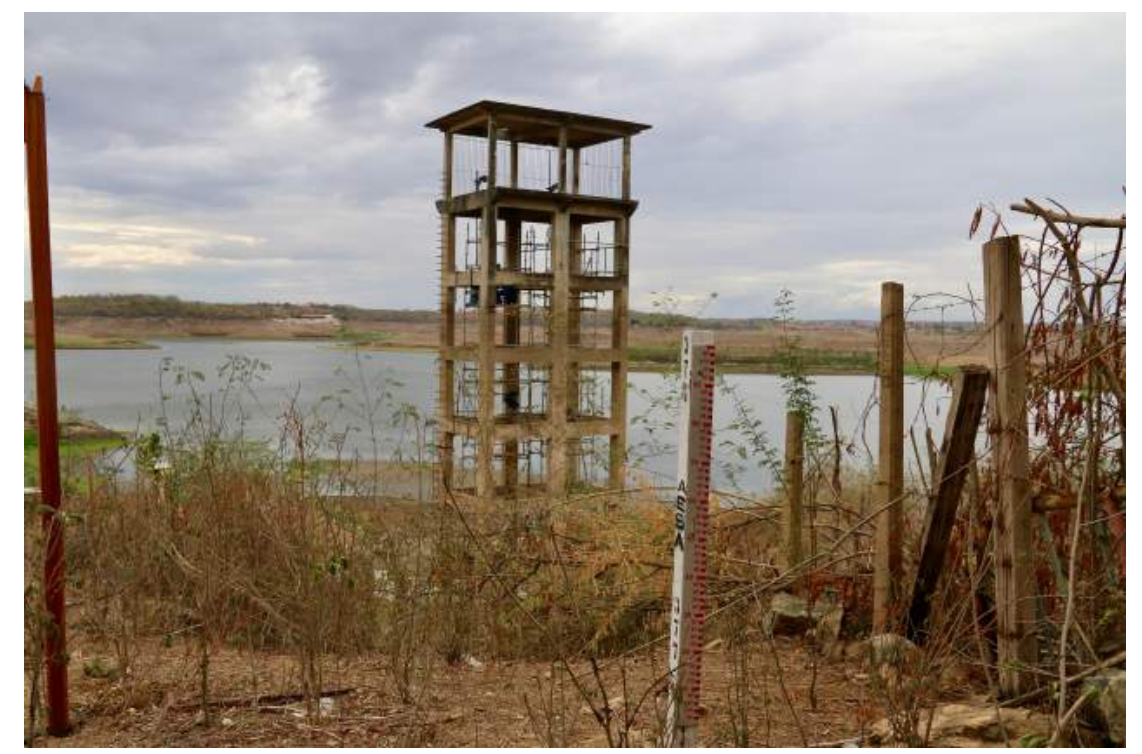

Nádia Pontes, março 2017

Figura 15 - Tomada d'água seca do Reservatório Epitácio Pessoa, PB, em decorrência do ciclo de seca iniciado em 2012

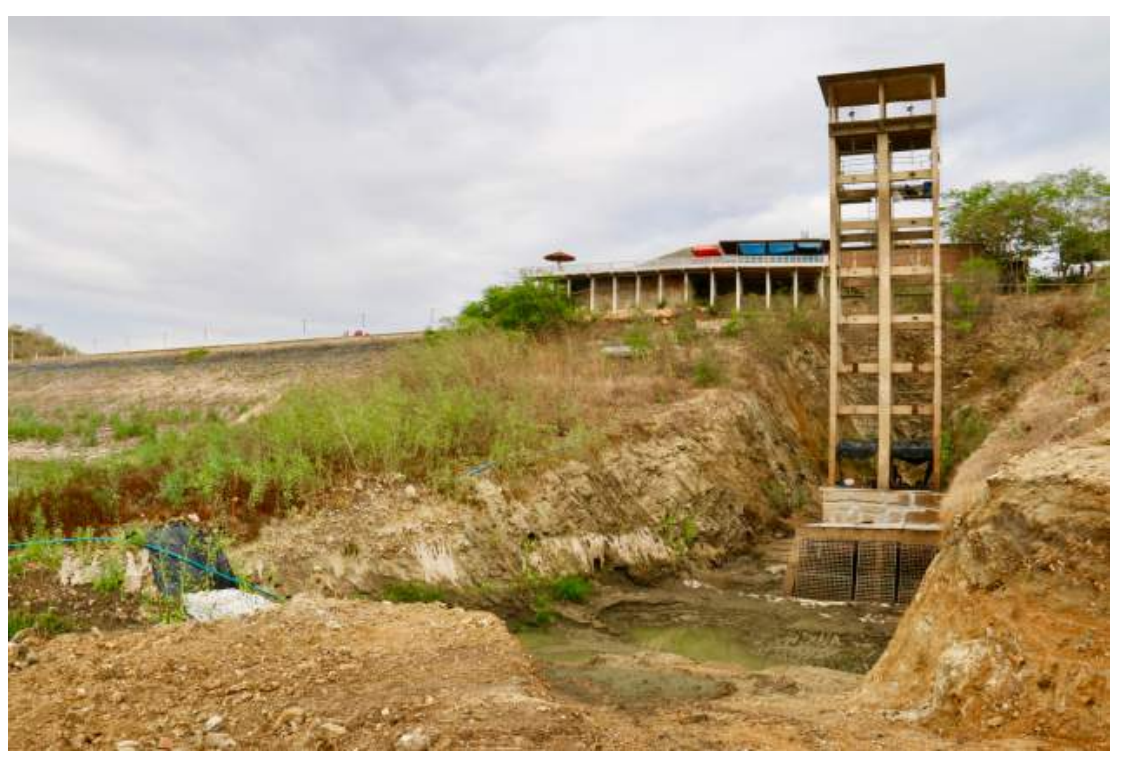

Nádia Pontes, março 2017 
O lago de Epitácio Pessoa foi planejado para cobrir uma área de 2.680 hectares, com capacidade de acumular um volume de $411.686 .287 \mathrm{~m}^{3}$. A primeira adutora para abastecer a população de Campina Grande a partir do açude foi construída em 1952, após uma grave crise hídrica na cidade. Posteriormente, o açude possibilitou o desenvolvimento de atividades econômicas no seu entorno como agricultura e piscicultura. A partir da década de 1990, outros municípios da região passaram a receber água do Epitácio Pessoa. Seus principais usos são abastecimento humano estimado em 1 milhão de pessoas, dessedentação animal, irrigação e abastecimento industrial (RANGEL JUNIOR; SOUSA, 2014).

Um fator preocupante destacado no trabalho de Brito (2013) é que o açude não tem regularidade de recarga hídrica por estar localizado numa região semiárida. Nos períodos de estiagens prolongadas, como o registrado desde 2012, os riscos de desabastecimento aumentam.

Durante a primeira visita de campo, em março de 2017, verificou-se que o transporte da água do São Francisco pelo Eixo Leste até chegar na calha natural do rio Paraíba fazia parte de uma operação de emergência para abastecer o reservatório Epitácio Pessoa. Bombas emprestadas do governo de São Paulo operavam ininterruptamente para acelerar o enchimento dos reservatórios e apressar a chegada da água ao açude Epitácio Pessoa. A figura 16 mostra um desses equipamentos em operação no reservatório de Campos do PISF, com capacidade de bombear até 2.000 litros de água bruta por segundo.

A cidade de Campina Grande, maior do interior da Paraíba e dependente exclusivamente do açude, vivia um racionamento estrito, imposto pela escassez hídrica que afetava 26 núcleos urbanos, formados por 18 sedes municipais e 8 distritos (RÊGO, 2014).

Brito (2013) encontrou indícios que demonstram que a decisão de se construir o Eixo Leste do PISF está ligada ao risco de colapso de abastecimento ao qual Campina Grande está exposta. Isso porque as primeiras versões do projeto de transposição do rio São Francisco divulgadas no século XX pelo Ministério de Integração Nacional, como as propostas de 1984 e 1993, planejava a captação em apenas um canal, que seria o Eixo Norte.

O Eixo Leste passou a constar no projeto de transposição a partir dos anos 2000, logo após uma grave crise protagonizada pelos níveis baixos do açude Epitácio Pessoa, entre 1998 e 1999, que comprometeu seriamente o abastecimento de Campina Grande e suas atividades econômicas (BRITO, 2013; RÊGO, 2014). 
Figura 16: Bomba em operação no reservatório de Campos do PISF para acelerar a chegada de água ao açude Epitácio Pessoa, PB

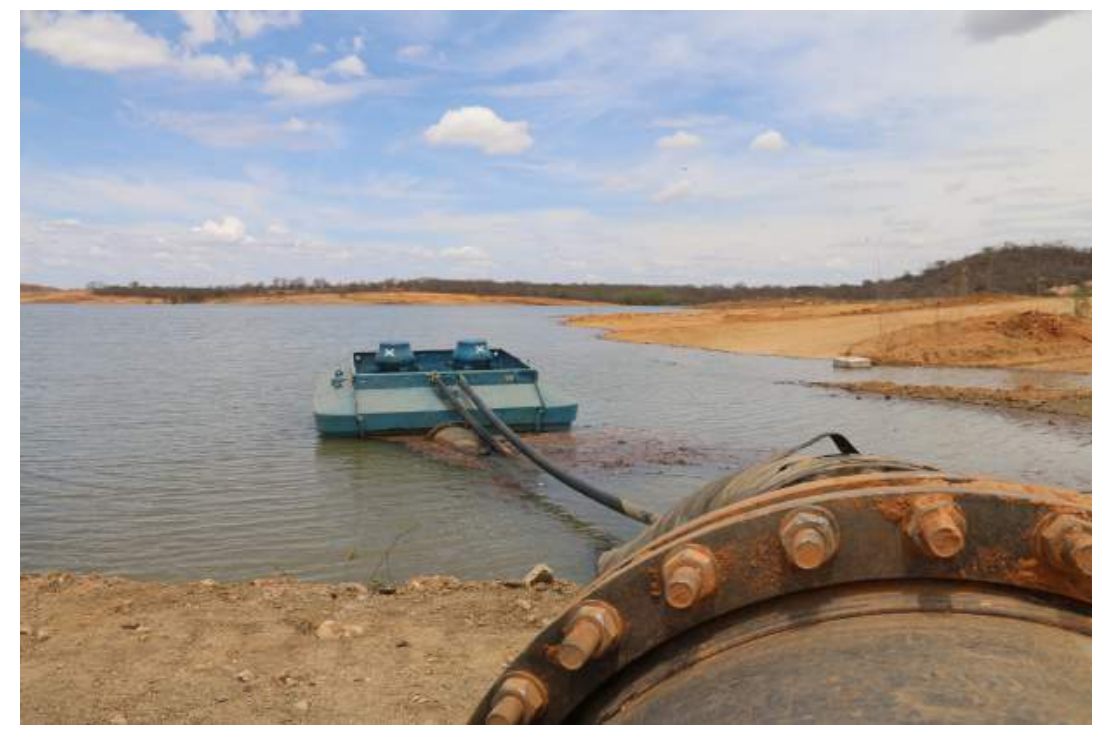

Nádia Pontes, março 2017

\subsection{COMUNIDADES RURAIS AO LONGO DO EIXO LESTE DO PISF E A DEPENDÊNCIA DE CAMINHÕES-PIPA}

Quanto às cidades onde o Eixo Leste do PISF atravessa, tanto no estado de Pernambuco como na Paraíba, observou-se que as áreas rurais de Floresta, Ibimirim, Custódia, Sertânia e Monteiro dependiam exclusivamente de caminhões-pipa para abastecimento humano, conforme dados coletados em visita de campo. As áreas urbanas, igualmente, passavam por racionamento de água ou abastecimento irregular. Embora presenciassem a chegada da água do rio São Francisco correndo pelos canais do Eixo Leste do PISF, as autoridades municipais das respectivas cidades demonstravam não ter clareza quanto à distribuição da água da transposição para as zonas vulneráveis e afetadas pela seca extrema registrada na região desde 2012.

A presente análise observou com maior profundidade o caso de Floresta, que tem a maior área dentre os demais municípios a serem abastecidos pelo Eixo Leste do PISF. Em março de 2017, momento da inauguração oficial da estrutura hídrica cujo término já havia se estendido por sete anos após o prazo inicial, a situação em Floresta era de calamidade pública, segundo o secretário de Produção Rural, Meio Ambiente e Recursos Hídricos, Túlio de Sá Laranjeira Ferraz. Dados obtidos em campo apontavam que 11 mil moradores de 278 
localidades do município dependiam da água levada às comunidades por 26 caminhões-pipa, que faziam 220 viagens por mês.

Dados do município indicam que, na região rural, cerca de 3,5 mil agricultores familiares produziam principalmente melão, melancia, tomate e cebola por meio da agricultura irrigada. Esses produtores, em anos de chuvas regulares, se utilizavam da água do riacho do Navio, que é intermitente, e do açude Barra do Juá. Com a seca extrema iniciada em 2012, porém, o cultivo ficou inviável.

Durante a segunda visita de campo, março de 2018, observou-se que a operação do Eixo Leste do PISF decorria de forma provisória, a chamada fase de teste, situação também verificada na primeira visita, em março de 2017, época em que as estruturas principais foram finalizadas. Ainda não havia clareza sobre o sistema de gerenciamento do sistema, sua operação e cobrança pelo uso da água aos usuários.

Na segunda viagem de campo, observou-se que a situação de abastecimento de água no município de Floresta permanecia grave. Os sistemas de abastecimento voltados para populações rurais difusas, segundo o Plano Ambiental 15, não haviam sido implementados. A responsabilidade da implementação dos sistemas ao longo do Eixo Leste foi repassada do Ministério da Integração Nacional para entidades estaduais em Pernambuco e Paraíba.

No estado de Pernambuco, as observações feitas em campo não condizem com os prazos originais estipulados pelo Plano de Trabalho entre MI, Compesa e Secretaria de Agricultura e Reforma Agrária (SARA). A Compesa, responsável pelos sistemas de distribuição de uso difuso de números 1, 13, 18 e 22, assinou o acordo com o MI em janeiro de 2016 com prazo original 24 meses, ou seja, janeiro de 2018. Em março de 2018, a visita de campo constatou o não cumprimento do prazo estabelecido no Plano de Trabalho original. Não havia sequer registro de início de obras dos referidos sistemas. Um novo documento, assinado em dezembro de 2017, prorrogou o prazo de implementação para 48 meses, contando a partir de dezembro de 2015 . O prazo, portanto, foi estendido para dezembro de 2019.

Já o Plano de Trabalho celebrado entre MI e SARA foi assinado em janeiro de 2016 com prazo inicial de 24 meses, ou seja, janeiro de 2018. A SARA é responsável pela implantação, gestão e operação da maioria dos sistemas: os de números $2,4,5,9,11,12,16$, 20, 21, 23, 24, 25, 26, 27 e 38. Como ocorreu no caso dos sistemas sob responsabilidade da 
Compesa, a visita de campo realizada em março de 2018 constatou o não cumprimento do prazo estabelecido no Plano de Trabalho original. Um novo documento, assinado em dezembro de 2017, prorrogou o prazo de implementação para 48 meses.

No estado da Paraíba, o mesmo padrão foi observado. O Plano de Trabalho acordado entre MI e Secretaria de Infraestrutura Hídrica do estado, assinado em janeiro de 2016 , estipulou o prazo inicial de entrega dos sete sistemas de Monteiro (28, 29, 30, 31, 35, 36 e 37) para janeiro de 2018. Durante a segunda visita de campo, tais sistemas não estavam em processo de implementação. Um novo Plano de Trabalho estendeu o prazo para 36 meses, a contar a partir de dezembro de 2015.

\subsection{FURTO DE ÁGUA DOS CANAIS DO EIXO LESTE DO PISF}

Com o não cumprimento do prazo original estabelecido para todos os sistemas de distribuição de uso difuso nos estados de Pernambuco e Paraíba, conforme a observação em campo, o furto de água dos canais do Eixo Leste passou a acontecer. Ao longo do percurso dos 217 quilômetros repetidos na segunda visita de campo, em março de 2018, não foi incomum encontrar sistemas clandestinos de captação de água, que vão desde bombas projetadas para maior volume a mangueiras simples que se utilizam de métodos artesanais.

O furto também é observado em localidades que não estão previstas para serem beneficiadas pelos sistemas de abastecimento de uso difuso. Esse é o caso da comunidade Serra Negra, em Floresta, distante 60 quilômetros do centro e a poucos metros de um canal do Eixo Leste do PISF. Nesse local, verificou-se que os moradores promoveram uma reorganização social para retirada da água da transposição.

A comunidade, de aproximadamente 300 pessoas, tem como única fonte de água para consumo humano os caminhões-pipa desde o agravamento do atual ciclo de seca, que se iniciou de 2012. Na ocasião da segunda visita de campo, em março de 2018, fazia três meses que o caminhão-pipa não abastecia as residências. As moradias da comunidade são equipadas com cisternas de 16 mil litros, volume que é consumido, em média, ao longo de um mês por uma família de quatro membros. Foi verificada ainda a presença de sistemas de coleta de água 
da chuva, que normalmente é direcionada aos pequenos cultivos que os moradores tentam manter, como mandioca, feijão e legumes.

Segundo dados coletados na prefeitura do município de Floresta, houve redução do abastecimento de caminhões-pipa de março de 2017 a março de 2018. Por conseguinte, os moradores recorreram a uma solução alternativa, visto que estão a poucos metros do canal do Eixo Leste do PISF. Um dos moradores, proprietário de uma bomba, passou a oferecer à comunidade um serviço clandestino para encher as cisternas das casas com água da transposição a custo de R \$ 30,00.

A bomba não fica à mostra durante o dia, é instalada durante à noite, quando a circulação de pessoas e veículos no local, já esmo, praticamente cessa. Esse serviço não oficial usa a infraestrutura de canos disponível no povoado, que distribuía água de um poço às residências. A bomba retira água do canal do Eixo Leste, envia para a pequena rede de tubulações e a água segue exatamente para a casa de quem pagou pelo serviço, o único a manter o registro aberto no momento da operação clandestina. Os demais moradores, avisados, deixam os registros fechados.

As figuras 17 e 18 mostram a proximidade da comunidade Serra Negra a um dos canais de PISF e o local onde a bomba é instalada para retirada clandestina de água.

Nas proximidades do município de Custódia, Pernambuco, ainda durante a segunda viagem de campo, foi possível observar o furto de água de moradores da comunidade Rio da Barra, conforme ilustra a figura 19. A comunidade aparece na lista do PBA 15 e deve ser beneficiada pelo sistema de distribuição de número 22 , de responsabilidade da Compesa. A captação da água nesse caso contava com um sistema mais simples, com uma mangueira comum, fazendo a retirada de água por meio do efeito sifão. Segundo a observação de campo, os moradores fazem a retirada do recurso natural com a finalidade de uso para higiene pessoal e para cozinhar.

Por outro lado, também foi possível registrar a retirada clandestina de água em maior volume para formação de reservatórios particulares em áreas de cultivo. Os canos instalados ilegalmente às margens do Eixo Leste se misturam intencionalmente a galhos secos de árvores típicas da caatinga, vegetação do semiárido, dificultando sua identificação, conforme ilustra a figura 20. Não é possível estimar o volume de água retirado por meio dessas ligações irregulares. 
Figura 17 - Comunidade rural Serra Negra, Floresta (PE) e sua proximidade a um dos canais do Eixo Leste do PISF

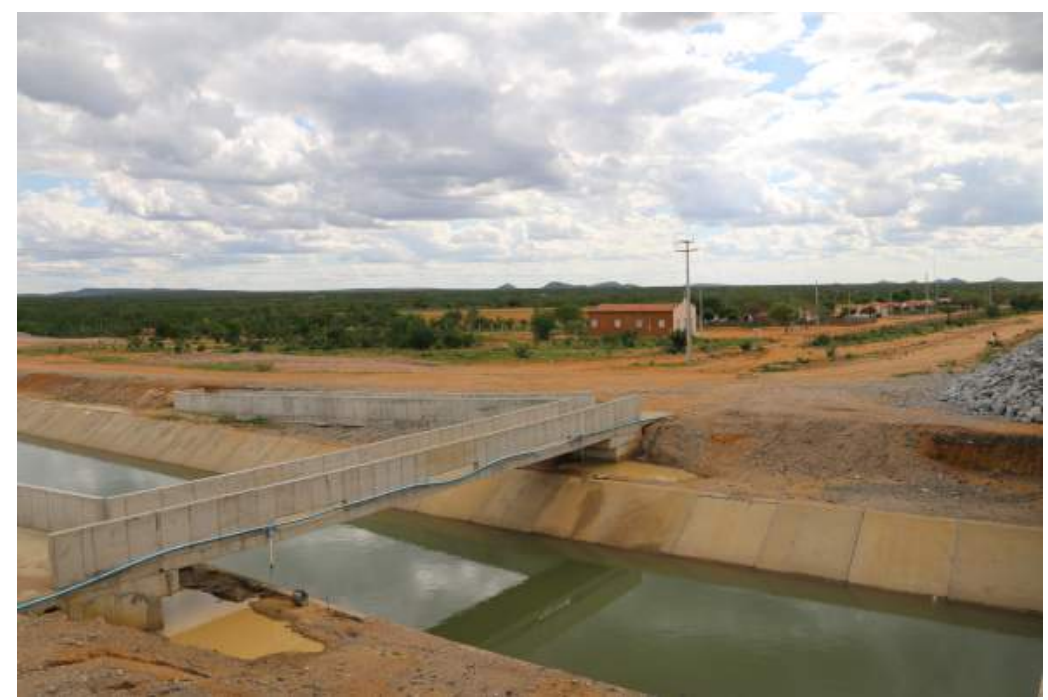

Nádia Pontes, março 2018

Figura 18 - Local onde bomba clandestina é instalada para retirada de água do Eixo Leste, com distribuição para comunidade Serra Negra, Floresta (PE)

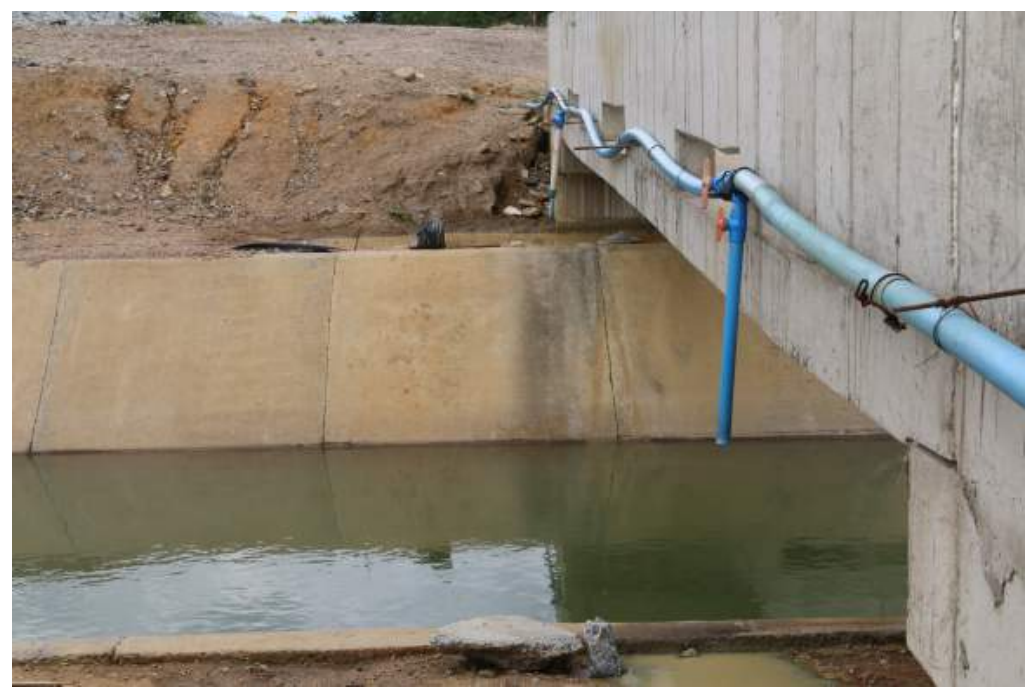

Nádia Pontes, março 2018 
Figura 19 - Morador retira água ilegalmente do Eixo Leste do PISF, Custódia (PE)
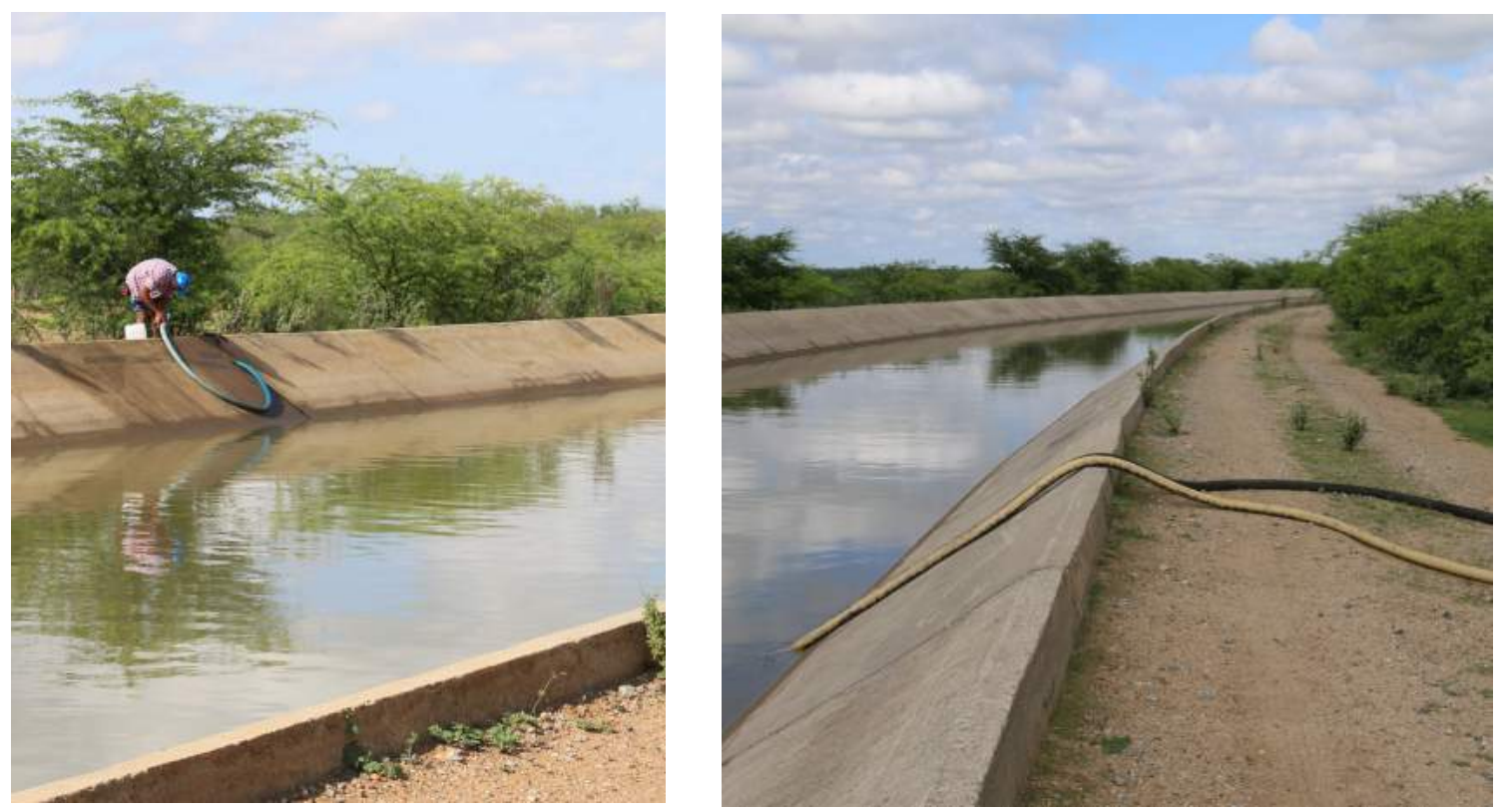

Fonte: Nádia Pontes, março 2018

Figura 20 - Retirada ilegal de água do Eixo Leste do PISF para formação de reservatório particular, Custódia (PE)
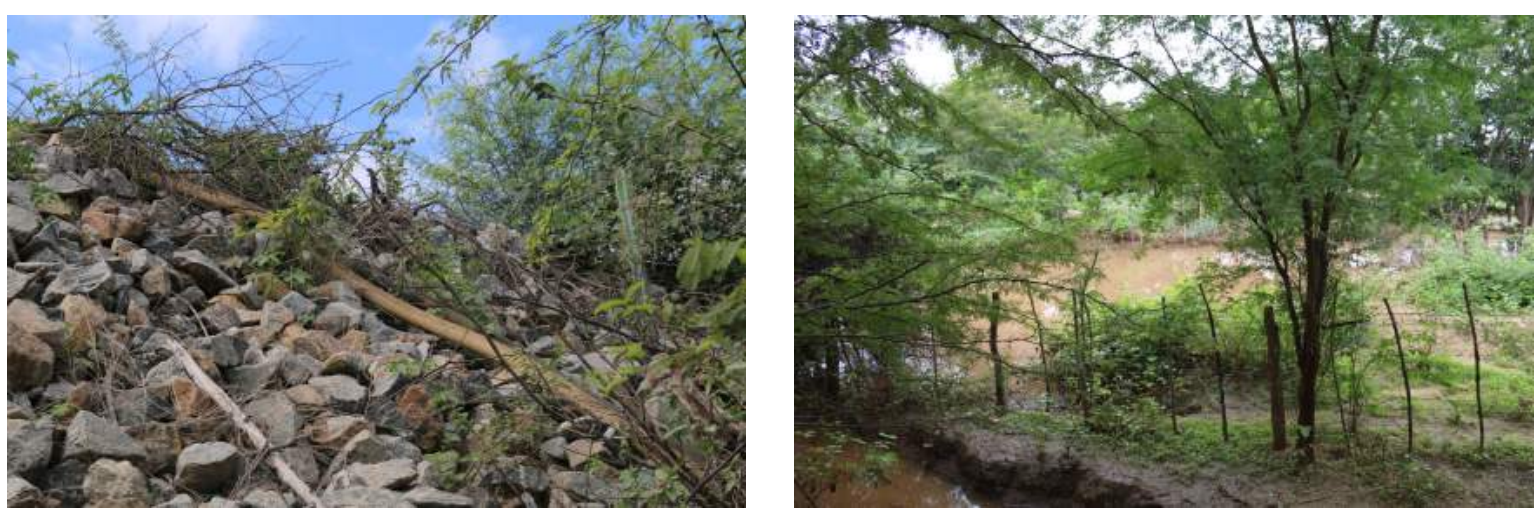

Fonte: Nádia Pontes, março 2018 


\section{4 ÁGUA DO EIXO LESTE DO PISF PARA IRRIGAÇÃO}

Enquanto aguardam a distribuição legalizada da água do rio São Francisco, autoridades municipais, parte da sociedade civil e de produtores familiares em Floresta interessados no uso do recurso para irrigação se organizaram para coletar dados no município e, dessa maneira, planejar de forma sustentável o uso do recurso natural. Prefeitura e cooperativas iniciaram um levantamento de informações quantitativas a fim de mapear os usuários distribuídos na área de abrangência do açude Barra do Juá e riacho do Navio, ambos beneficiados pelo PISF. O trabalho segue em andamento.

Segundo estimativa da prefeitura, a população rural do município é de aproximadamente 13 mil, ou seja, 39\% a mais que os 9312 indivíduos apontados pelo Projeto Executivo da Infraestrutura de Abastecimento de Água das Comunidades Diretamente Afetadas com a Implantação do PISF (CONSÓRCIO PROJETEC/ENGESOFT, 2014a). Ainda segundo a prefeitura de Floresta, de 4 mil a 5 mil produtores rurais seriam usuários do açude Barra do Juá e do riacho do Navio9. Os cooperados passaram a discutir maneiras de manejar a água da transposição prevista para abastecer o açude de forma mais eficaz, evitando desperdício, com emprego de tecnologias de irrigação que contribuam nesse sentido.

Embora o RIMA do PISF priorize a distribuição para consumo humano e dessedentação animal para populações do semiárido, o Projeto Executivo do Eixo Leste do PISF prevê derivação de parte do volume para projetos de irrigação. O reservatório de Muquém tem previsão de enviar até $10,0 \mathrm{~m} 3 / \mathrm{seg}$ para o abastecimento do açude Barra do Juá com o objetivo de abastecer o futuro Projeto de Irrigação Serra Negra, além dos usuários. A decisão de abrir a válvula dispersora que transfere água do açude para o riacho do Navio será do Conselho Gestor do Açude Barra do Juá.

Entre os pequenos agricultores reunidos na Cooperativa dos Criadores de Caprinos e Ovinos (Coopercapri), que contava com 671 cooperados em março de 2018, há a percepção de que a perenização do riacho do Navio por meio da água do Eixo Leste irá transformar a região de Floresta num "novo El Dorado" do estado de Pernambuco, em referência à lenda indígena sobre uma povoado na América do Sul coberto de ouro e esmeraldas. No caso de

\footnotetext{
9 Informação verbal concedida por Edmir Manoel de Souza, presidente da Cooperativa dos Criadores de Caprinos e Ovinos (Coopercapri).
} 
Floresta, os cooperados da Coopercapri acreditam que a disponibilidade de água permitirá a irrigação de pequenos cultivos e aumento da produção de caprino e ovino.

O açude Barra do Juá, que também recebe a denominação de Lagoa do Barro pelo DNOCS, foi implantado pelo órgão em fevereiro de 2000 com a finalidade de uso para irrigação. Inserido no município de Floresta, tem a capacidade de armazenar 71,4 milhões $\mathrm{m}^{3}$ de água.

Como consequência da irregularidade de chuvas no semiárido entre 2012 e 2017, o açude Barra do Juá chegou a esvaziar em 2016, como ilustra o gráfico 2. Em março de 2018, o volume total era de $5,4 \%{ }^{10}$. A figura 21 mostra uma visão panorâmica do açude Barra do Juá.

Gráfico 2 - Queda no nível do reservatório de Barra do Juá, Pernambuco

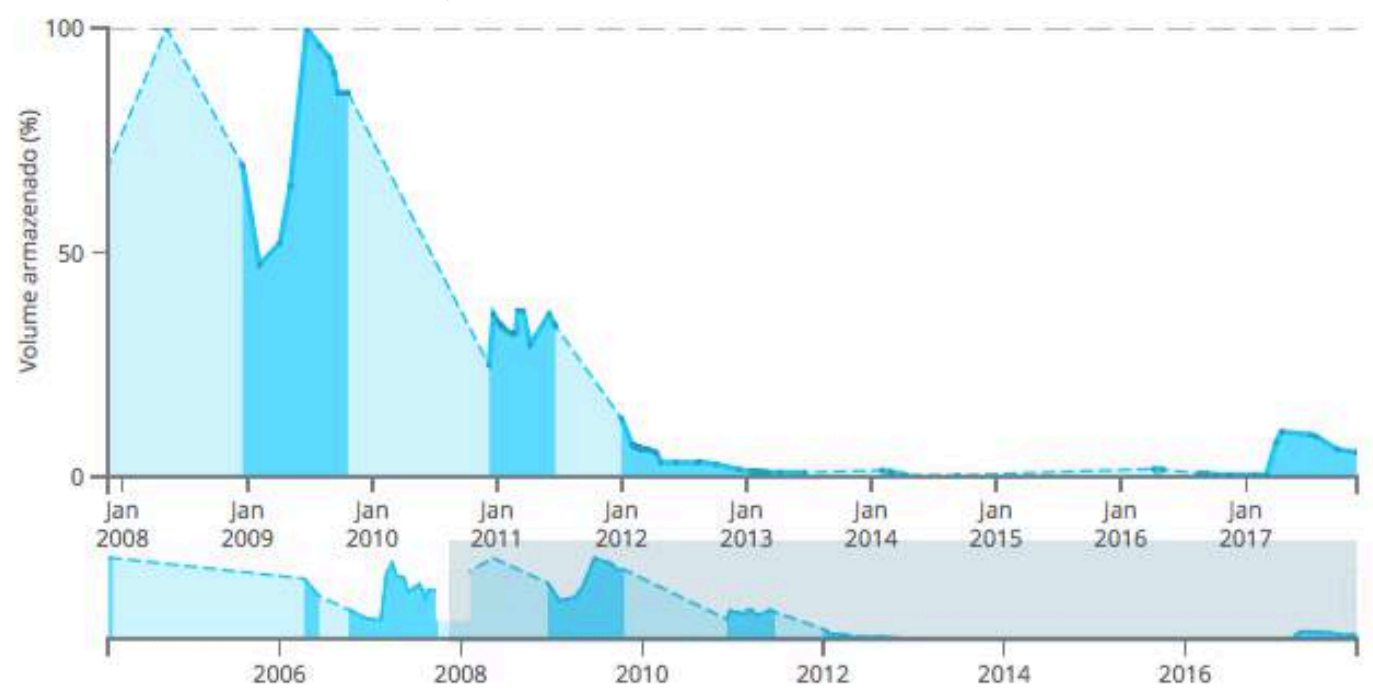

Fonte: INSA, 2018

Figura 21 - Visão panorâmica do açude Barra do Juá, Floresta, PE

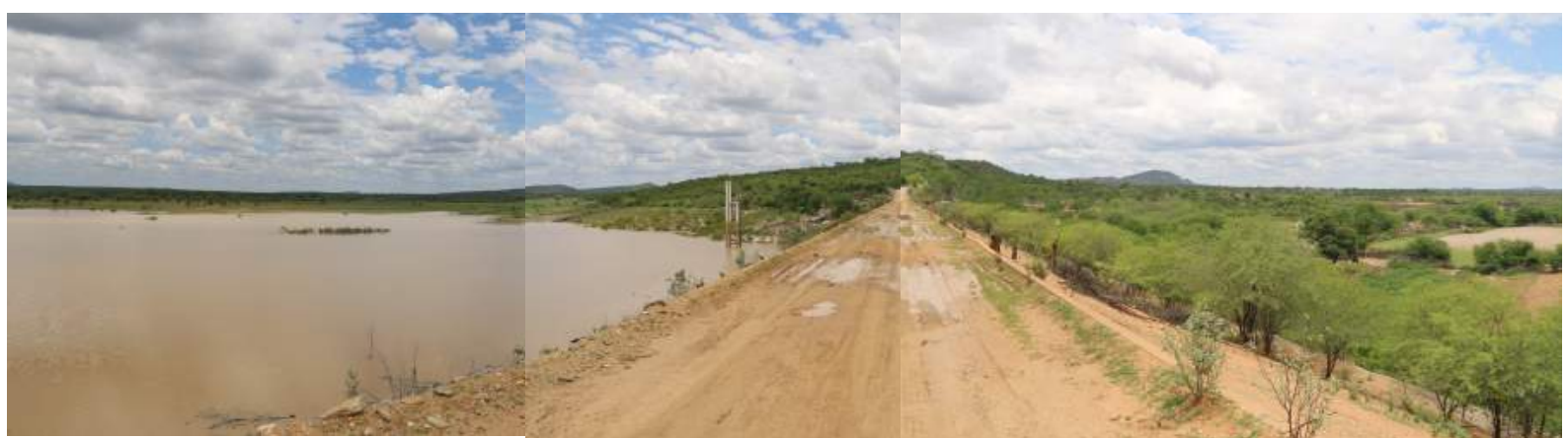

Nádia Pontes, março 2018

10 Informação disponível em https://olhonagua.insa.gov.br/\#!/?id=12042\&reservatorio=barra_do_jua 
Também previsto para ser beneficiado pelo Eixo Leste do PISF, o açude Poço da Cruz deve receber água a partir da barragem Copiti. A estrutura foi projetada para transportar até $18,00 \mathrm{~m}^{3} / \mathrm{seg}$ com a finalidade de suprir o Perímetro de Irrigação do Moxotó (CONSÓRCIO TECHNE-PROJETEC-BRLi, 2012).

O açude começou a ser construído na década de 1930, é de administração do DNOCS. Está dentro dos limites dos municípios de Ibimirim e Inajá (PE) e tem capacidade para armazenar 504 milhões $\mathrm{m}^{3}$ de água. Como Barra do Juá, Poço da Cruz, cujo nome oficial é Engenheiro Francisco Saboia, foi construído para atender projetos de irrigação e conta com um perímetro irrigado, que se estende por cerca de $40 \mathrm{~km}$. A implantação do perímetro irrigado iniciou-se em 1972, já a operação de uso comum foi em 197711.

O gráfico 3 ilustra a variação do volume do açude Poço da Cruz nos últimos anos. Em março de 2018, durante a segunda visita de campo, o volume do açude era de $6,2 \%$, e não havia previsão para que o açude passasse a receber água a partir do reservatório de Copiti, parte do Eixo Leste do PISF.

Gráfico 3 - Queda no nível do reservatório de Poço da Cruz, Pernambuco

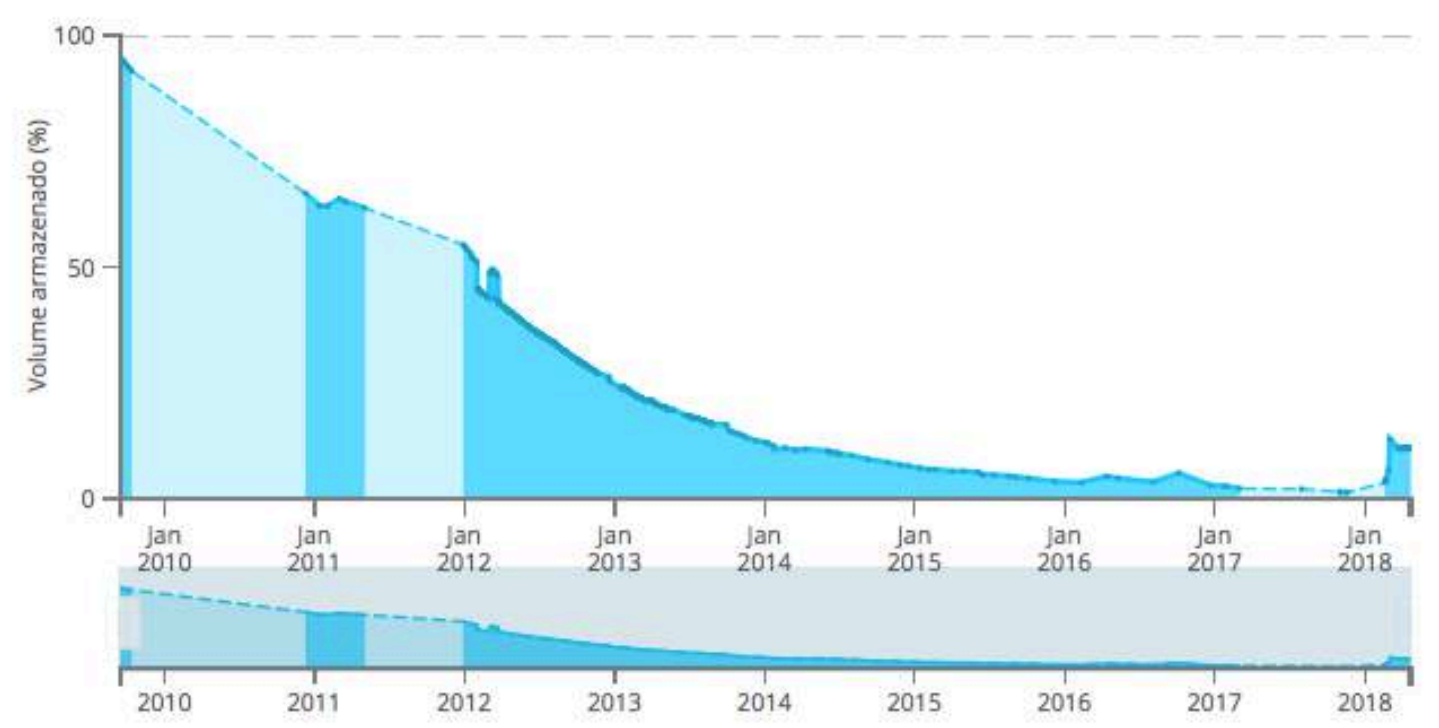

Fonte: INSA, 2018

${ }^{11}$ Informação disponível em http://www.dnocs.gov.br/ dnocs/doc/canais/perimetros_irrigados/pe/moxoto.htm. Consultado em março de 2018. 
A partir da formação do lago, comunidades se instalaram na região e desenvolveram atividade pesqueira e agricultura, com cultura de vazante. O perímetro é composto por 565 lotes agrícolas, que sofreram, ao longo das décadas, ritmo de expansão e contração das atividades, segundo a disponibilidade de água (SILVA; VASCONCELOS, 2015).

A disponibilidade de água no Eixo Leste para transferência ininterrupta de volumes para os dois açudes previstos, no entanto, é incerta, como mostrou a análise feita por Melo (2010). Com base no projeto do PISF, o estudo avaliou a proposta de transferência do rio São Francisco para Pernambuco e Paraíba, com propósito de abastecimento humano e irrigação, através dos canais do Eixo Leste, reservatórios e adutoras. Foram usados modelos de simulação hidrológica e técnicas de otimização para avaliar o comportamento dos reservatórios que compõem o sistema, desde o reservatório de Sobradinho, fonte de regularização do sistema, até a Paraíba. O trabalho concluiu que, a partir de vazões afluentes ao lago de Sobradinho, cujo volume condiciona as regras de outorga para a transposição, as condições da outorga para atendimento à irrigação ocorreriam em $41 \%$ do tempo. Nos restantes $59 \%$ do período simulado, apenas o abastecimento humano poderia ser atendido.

Melo (2010, p. 131 ) observa ainda que:

Por outro lado, o volume acumulado em Sobradinho depende da geração de energia, que depende por sua vez da decisão da ONS - Operador Nacional do Sistema Elétrico. Esse é um ponto potencial de conflito, dado que a decisão de transferir água para irrigação não fica associada apenas às variáveis hidrológicas na bacia do rio São Francisco e sim ao planejamento do setor elétrico como um todo.

\subsection{BAIXO VOLUME DO RIO SÃO FRANCISCO E DE SOBRADINHO}

Acima de tudo, para que o volume de Sobradinho garanta o desvio de água pelos eixos Norte e Leste, é preciso que a vazão do rio São Francisco esteja em condições favoráveis. O ciclo de seca mais recente, iniciado em 2012, trouxe impactos preocupantes à bacia, como demonstrou o trabalho de Sun et al (2016).

Os autores verificaram a disponibilidade de água na bacia do rio São Francisco por meio do sistema Gravity Recovery and Climate Experiment (GRACE), que consiste em dois satélites da National Aeronautics and Space Administration Espacial (NASA), agência norteamericana. Os satélites rodeiam a órbita da Terra desde 2002 e medem as mudanças no campo 
gravitacional da Terra, diretamente relacionadas às mudanças na massa da superfície. Dessa maneira, é possível medir o armazenamento total de água (TWS)12.

Usando o sistema GRACE, Sun et al (2016) mediram a perda de água de abril de 2002 a março de 2015 na bacia do São Francisco e observaram taxa de $-3.30 \mathrm{~km}^{3} / \mathrm{ano}$. Por outro lado, a perda de água no período de fevereiro de 2012 a janeiro de 2015, anos do mais recente ciclo de seca, foi de $-27.63 \mathrm{~km} 3 /$ ano, dados que vão ao encontro da queda de precipitação verificada no período.

Embora o estudo não associe diretamente o evento extremo às mudanças climáticas, os autores não descartam essa possiblidade e afirmam que novas análises das causas para o fenômeno são urgentes (SUN et al, 2016).

Ao mesmo tempo em que as obras do Eixo Leste do PISF seguiam, o volume do reservatório de Sobradinho sofreu redução drástica em seu volume, em concordância com a queda da precipitação registrada. O lago de Sobradinho, no estado da Bahia, começou a ser formado em 1973 para aproveitamento hidrelétrico e regularização de fonte hídrica na região. O lago e a operação são da Companhia Hidroelétrica do São Francisco (Chesf), subsidiária da Eletrobras, tem cerca de $320 \mathrm{~km}$ de extensão, um espelho d'água de $4.214 \mathrm{~km}^{2}$ e capacidade de armazenamento de 34,1 bilhões $\mathrm{m}^{3}$. O gráfico 4 mostra a variação do volume do lago de Sobradinho nos últimos 10 anos, segundo dados da ANA.13

Gráfico 4 - Queda no nível do reservatório de Sobradinho, Bahia

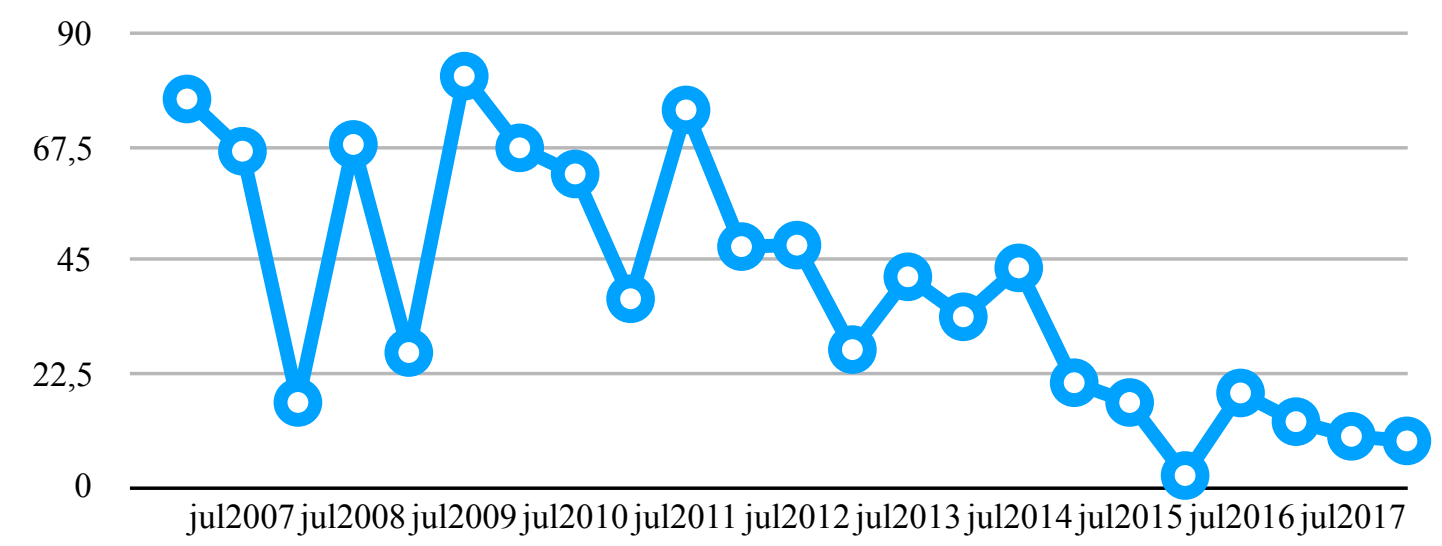

Fonte: ANA, 2018

\footnotetext{
12 Informação disponível em: https://www.nasa.gov/mission_pages/Grace/index.html. Consultado em 25 de abril 2018.

13 Informações disponíveis em https://www.chesf.gov.br/SistemaChesf/Pages/SistemaGeracao/Sobradinho.aspx. Consultado em 20 de abril 2018.
} 


\section{ANÁLISE INTEGRADA}

\subsection{PLANEJAMENTO DO PISF E MUDANÇAS CLIMÁTICAS}

O projeto de integração do Rio São Francisco com as Bacias Hidrográficas do Nordeste Setentrional foi previsto para ser executado no semiárido do nordeste brasileiro, região historicamente conhecida por sua variabilidade climática, longos períodos de estiagem, com histórico de prejuízos aos residentes trazidos pela seca. Somam-se a essas características fatores socioeconômicos da região, que concentra significativa parcela da população pobre do país, moradores de áreas rurais que vivem da agricultura de subsistência, ou de programas sociais do governo federal mais recentemente.

Com a seca recente iniciada a partir de 2012, a agricultura de subsistência no semiárido ficou inviável em muitas regiões. Sem fonte de renda regular, muitas famílias dependiam da aposentadoria de um dos membros, que chegava a sustentar até 20 pessoas. A Articulação no Semiárido Brasileiro (ASA), rede com mais de 3 mil organizações, observa que os impactos do evento extremo de seca dificultam ou inviabilizam a vida no semiárido. A ASA relata perda de animais, desestruturação de sistemas produtivos e de vidas, do aumento da pobreza na região. Programas sociais como Bolsa Família e Garantia Safra, políticas públicas de sobrevivência no semiárido, construção de cisternas, a garantia de pelo menos uma refeição ao dia para as crianças, por meio da merenda escolar, são os principais fatores que evitaram um abandono massivo do espaço geográfico, aponta a $\mathrm{ASA}^{14}$.

Esses são fatores que contribuem para que o semiárido nordestino seja uma das regiões mais vulneráveis do país. O avanço das mudanças climáticas previstas para a região agrava a situação. A literatura voltada para o tema prevê, com grande nível de certeza, elevação da temperatura, queda de precipitação, diminuição de escoamento superficial até o fim do século (IPCC, 2014; PBMC, 2014). Algumas dessas alterações já foram observadas na região, como aumento de temperatura em $3^{\circ} \mathrm{C}$ e $4^{\circ} \mathrm{C}$ em localidades de Pernambuco, aumento de dias de estiagem, queda na precipitação, diminuição da vazão do rio São Francisco (NOBRE, 2011; NOBRE et al, 2011; SUN et al, 2016; DE JONG, 2018).

\footnotetext{
14 Informação concedida em entrevista publicada em http://www.dw.com/pt-br/as-marcas-da-seca-no-nordeste/
} a-42863630 
Por outro lado, a maior obra de infraestrutura hídrica do país, proposta como solução à insegurança hídrica do semiárido nordestino, não incorporou essas variáveis ao seu planejamento. Embora tenha sido apresentado pela primeira vez há mais de um século (MINISTÉRIO DA INTEGRAÇÃO NACIONAL, 2004), o projeto de integração do Rio São Francisco com as Bacias Hidrográficas do Nordeste Setentrional ganhou diversas versões até chegar a que se encontra em execução desde 2007. Manteve-se porém a abordagem conceitual antiga, em que projetos de transposição são vistos como mera transferência de água entre bacias.

O RIMA não debateu publicamente impactos sobre mudanças climáticas na região previstos por estudos científicos, não abordou medidas de adaptação com vistas a assegurar a sobrevivência das populações rurais que tradicionalmente praticam agricultura de subsistência na região, ou ofereceu um plano alternativo às populações rurais difusas previstas para serem atendidas caso a transferência de água pelos canais seja insuficiente. Como mencionado anteriormente, o termo "mudanças climáticas” sequer é citado no RIMA.

Desde que o PISF passou a ser executado, numerosos estudos voltados para os impactos das mudanças climáticas no Nordeste e sobre seus recursos hídricos se multiplicaram. Percebe-se, contudo, uma dificuldade do poder público em incorporar e integrar tais discussões científicas ao planejamento e execução das obras do PISF em sua totalidade, em especial ao Eixo Leste. Isso não quer dizer, entretanto, que o tema não esteja na pauta de órgãos oficiais. A própria ANA tem publicações voltadas para o debate dos impactos das mudanças climáticas sobre os recursos hídricos no Nordeste (CENTRO DE GESTÃO E ESTUDOS ESTRATÉGICOS, 2012). Por outro lado, não se vê a integração dos resultados no âmbito da execução do PISF.

Ao mesmo tempo em que as obras do Eixo Leste se delongavam, ultrapassando em sete anos o prazo inicialmente estabelecido, que era 2010, a região do semiárido enfrentava um longo ciclo de seca, iniciado em 2012. Segundo análise de Marengo, Cunha e Alves (2016), o evento de seca tinha intensidade e impacto não observados há várias décadas, acarretaram significativas perdas agrícolas, prejuízos aos pequenos produtores, desestruturação de grandes áreas de terras agrícolas, com grandes prejuízos à população.

Como a literatura prevê que eventos climáticos extremos como o observado recentemente no semiárido ficarão mais intensos e mais frequentes (IPCC, 2014; PBMC, 
2014), podendo agravar a já conhecida situação de vulnerabilidade das populações residentes, fica evidente que a operação e distribuição de água dos canais do Eixo Leste são questões centrais. A distribuição da água trazida pelos canais do Eixo Leste para a região marcada pela escassez exerce, portanto, forte influência quando se considera a adaptação dessas populações ao cenário previsto e a permanência dessas comunidades no semiárido.

Vale ressaltar que o empreendimento do PISF se justifica por garantir que a intervenção atenderá às necessidades de abastecimento de municípios do semiárido brasileiro, Agreste Pernambucano e Região Metropolitana de Fortaleza, tendo sido apresentado como a solução para os problemas trazidos pela escassez de água nas regiões citadas (MINISTÉRIO DA INTEGRAÇÃO NACIONAL, 2004).

Em seu primeiro ano de funcionamento em fase teste, no entanto, notam-se deficiências em termos operacionais no Eixo Leste que comprometem o cumprimento dos objetivos. Durante as visitas de campo, constatou-se que os canais e reservatórios do Eixo Leste não dispunham de medidores de vazão que permitissem um planejamento do volume exato de transferência e consumo de água. Segundo o RIMA, a previsão é que o Eixo Leste do PISF transporte, em média, 18,3 m³ (MINISTÉRIO DA INTEGRAÇÃO NACIONAL, 2004). Além disso, apenas uma das duas válvulas dispersas nas tomadas d'água estava instalada nos reservatórios.

Da mesma forma, o baixo nível de água registrado no período no reservatório de Sobradinho, que condiciona o volume a ser transferido pelo Eixo Leste, trouxe incerteza quanto ao abastecimento previsto pelo PISF, o que dificulta o planejamento dos órgãos responsáveis pelo atendimento da demanda nos estados beneficiados.

O documento em que a ANA (2005) concede o direito de outorga ao MI para operação do PISF afirma que há vazão firme disponível para bombeamento "a qualquer momento" de $26,4 \mathrm{~m}^{3} / \mathrm{s}$, nos dois eixos. O documento não cita em quais condições o bombeamento de água bruta de Sobradinho para o PISF deve ser suspenso, ou se existem riscos de o transporte desse volume não ocorrer devido a condições climáticas. Quando se considera a queda no nível do reservatório registrada nos últimos anos, em concordância com a queda da precipitação e da vazão do rio São Francisco registradas, coloca-se em dúvida o suprimento futuro do PISF com o avanço das mudanças climáticas. 
As observações em campo contrastam com o que recomendam autores como Zhang et al (2014), que concluem que o avanço das mudanças climáticas impactam operações padrão de gerenciamento dessas infraestruturas, o que exige maior precisão no planejamento, design e estágios de operações de grandes projetos de transposição. Afinal, tais obras requerem elevadas somas de dinheiro e são construídas com o intuito de operar por séculos.

\subsection{FORNECIMENTO DE ÁGUA DO EIXO LESTE DO PISF E ADAPTAÇÃO Às MUDANÇAS CLIMÁTICAS}

A região do semiárido sob influência do PISF se enquadra segundo os conceitos-chaves adotados no estudo de adaptação às mudanças climáticas definidos por Brooks (2003). Ela sofre o "perigo" entendido como as manifestações físicas da variabilidade climática ou mudanças climáticas, como as secas. E também sofre com a "vulnerabilidade" biofísica e social, ou seja, os impactos de um evento de perigo (biofísico) e fatores como desigualdade, pobreza, déficit alimentar, déficit educacional, falta de acesso a serviços de saúde, más condições habitacionais (vulnerabilidade social). A combinação das vulnerabilidades biofísica e social podem, portanto, causar perdas de vidas, bens, provocar altos custos públicos entre outros (BROOKS, 2003; JONES; BOER, 2003).

Com base nas visitas de campo e análises de documentos, pode-se afirmar que em seu primeiro ano de funcionamento, o Eixo Leste do PISF não priorizou as populações mais vulneráveis, previstas para serem atendidas com abastecimento de sistemas estipulados no PBA 15. Em seu cronograma original, o PBA 15 estipulou o fim do ano de 2015 como prazo final (MINISTÉRIO DA INTEGRAÇÃO NACIONAL, 2005). Os Planos de Trabalho celebrados com as entidades estaduais, em janeiro de 2016, em vista do atraso das obras do PISF como um todo, estipularam novos cronogramas para a implantação dos sistemas difusos, que deveriam ser cumpridos até janeiro de 2018. Os prazos estipulados também não foram observados e, portanto, estendidos, de 24 meses para 48 meses (Anexo 1, 2, 3, 4 e 5).

O atraso da entrega dos sistemas de uso difuso, ainda no desenrolar do evento de escassez prolongada, fez com que parcela significativa das comunidades do entorno do Eixo Leste do PISF buscasse vias clandestinas para retirar água dos canais, burlando as regras e 
expondo a momentânea incapacidade do PBA 15 de cumprir objetivos importantes. Com a ausência de distribuição de água do PISF a essas comunidades rurais difusas, coloca-se em dúvida outra meta do projeto relacionada a questões econômicas, que previa redução de gastos públicos com programas e medidas de emergência adotadas durante períodos de severa escassez de água, como contratação de caminhões-pipa. Além dos riscos à saúde pública, visto que a água extraída clandestinamente em sua forma bruta, sem qualquer tratamento, expõe os consumidores, muitos já com déficit nutricional, a doenças.

Embora o PISF não tenha sido nomeado oficialmente como uma medida de adaptação às mudanças climáticas, o projeto de transposição não fica isento dessa responsabilidade. Pois, em sua concepção, o PISF estabelece entre seus propósitos se tornar um empreendimento que garanta a segurança hídrica numa porção do semiárido nordestino, que viabilize a permanência da população rural no local e melhore as condições de vida, marcada pela pobreza e falta d'água, além de pretender beneficiar a população urbana, pequenos e grandes agricultores, gerar empregos, renda e trazer melhoria na qualidade de vida (MINISTÉRIO DA INTEGRAÇÃO NACIONAL, 2004). E essa é uma das regiões mais vulneráveis às mudanças climáticas no país, onde a situação de escassez hídrica deverá se agravar.

Segundo a literatura, a discussão sobre a necessidade de adaptação normalmente surge a partir de experiências com eventos extremos. Füssel (2007a) preconiza que quando esses fenômenos expõem a vulnerabilidade da região ou população afetadas, a variabilidade climática e as mudanças climáticas provocadas pela ação do homem precisam ser consideradas em conjunto, justamente porque é a combinação desses dois fatores que aumenta os riscos. Medidas de adaptação voltadas à variabilidade climática são sugeridas como ponto de partida por Klein (2003), pois são vistas como estratégias para reduzir a vulnerabilidade de regiões e populações à variabilidade climática, e servem para demonstrar a capacidade, iniciativa e habilidade de uma região, ou país, para se adaptar às mudanças climáticas.

Tendo em vista essa recomendação de Klein (2003), o PISF pode ser considerado um ponto de partida como medida de adaptação às mudanças climáticas, visto que a grande variabilidade climática na região de influência do empreendimento é reconhecida no RIMA (2004). 
A abordagem baseada na vulnerabilidade, usada nessa pesquisa, considera que fatores sociais influenciam a habilidade de uma região ou população para se adaptar às mudanças climáticas. Além disso, a abordagem é recomendada para identificar áreas prioritárias, analisar a efetividade de medidas específicas de intervenção, analisar a relação entre riscos relacionados ao clima e de riscos não climáticos, analisar a limitação de recursos como dados, dinheiro, tempo e expertise. Nessa abordagem, a adaptação é altamente dependente do contexto específico porque depende de condições climáticas, ambientais e políticas da região ou setor em questão (LIM et al, 2005; FÜSSEL, 2007b). No caso do PISF, nota-se que essa abordagem foi considerada indiretamente, sem ser nomeada como tal, na confecção do RIMA, porém não se observa sua implementação no momento da distribuição de água pelo Eixo Leste.

A maneira como a responsabilidade sob a implementação dos sistemas de distribuição de água para uso difuso foi atribuída também pode influenciar a efetividade do PISF. Ao repassar a competência a órgãos estaduais de menor corpo técnico e orçamento, como Secretaria da Agricultura e Reforma Agrária do estado de Pernambuco, as obras e os prazos para que a população mais vulnerável seja atendida ficam comprometidos. Como ressalta Klein (2003), nenhuma intervenção irá funcionar num ambiente que não está preparado, não tem capacidade ou não quer receber a medida de intervenção. Logo, o incremento das capacidades tecnológica, industrial, legal e econômica, assim como a conscientização são prérequisitos para uma adaptação efetiva.

Embora o estado de Pernambuco tenha um Plano de Enfrentamento às Mudanças Climáticas, o que não se observa no estado da Paraíba, ainda não é perceptível uma articulação entre os objetivos apresentados no Plano e a operação do PISF. Como exemplo, tem-se a ausência de informação por parte das autoridades municipais pernambucanas que estão na área de influência do Eixo Leste sobre o Plano estadual e sobre como suas metas poderiam ser incorporadas quanto à priorização da distribuição de água ao longo do Eixo Leste do PISF.

Assim como o Plano Nacional de Adaptação à Mudança do Clima, o Plano de Enfrentamento às Mudanças Climáticas de Pernambuco contempla alguns aspectos teóricos preconizados por Klein (2003), Füssel (2007a), Basset e Fogelman (2013). No entanto, notase a delonga quanto à aplicação quando se consideram especialmente planos de adaptação 
integrada, revisão das metas a fim de efetuar um trabalho contínuo, importância de se analisar vulnerabilidades, trabalho com diferentes setores da sociedade e disseminação de informação.

\subsection{GESTÃO DO PISF E DESAFIOS DE GOVERNANÇA}

Nota-se ainda que questões apontadas no início das obras por Empinoti (2011) e Henkes (2014) persistiram, como a dificuldade em resolver os problemas da população mais pobre e o descrédito na gestão hídrica participativa, hiato entre lei e práticas oficiais.

O projeto de transposição do rio São Francisco, por sua complexidade e amplitude, traz também um grande desafio de governança. Embora o CBHSF integre o Conselho Gestor, ainda não é clara como será a sua efetiva participação. Como destaca Empinotti (2011), os comitês de bacias ainda são considerados como órgãos deliberativos pelo Estado. Consequentemente, é possível que surjam tensões entre os setores participantes do sistema de gestão e suas expectativas com relação à função e nos processos de tomada de decisão. Por outro lado, a organização dos usuários das bacias receptoras ainda se mostra incipiente e difusa, observando-se a marginalização dos usuários moradores de comunidades rurais no processo.

Isso porque, no Brasil, as discussões são ainda fortemente controladas por grupos com conhecimento técnico e discurso sofisticado, o que privilegia representantes do Estado e do setor privado e favorece as decisões de acordo com os interesses econômicos presentes (EMPINOTTI, 2011).

Em seu primeiro ano de operação, não ficou claro como o sistema de informações relativo à distribuição do Eixo Leste irá funcionar, assim como o monitoramento das outorgas. Portanto, essas questões evidenciam o desafio de gestão e de governança das águas desviadas do rio São Francisco. Dada a complexidade do uso da água dentro da bacia, desenvolvê-la, alocá-la e administrá-la de forma equitativa e eficiente, e garantir a sustentabilidade ambiental exige que as diferentes vozes sejam ouvidas e respeitadas nas decisões sobre seu uso, segundo o conceito de Rogers e Hall (2003).

Algumas experiências internacionais em projetos de transposição de água indicam que a abordagem da governança nesses casos é complexa. Em 2014, uma seca extrema na província 
de Henan, na China, levou as autoridades locais a transpor águas para as regiões mais afetadas. Embora a China não tenha um regime político democrático, o caso evidencia a importância da boa articulação dos atores envolvidos.

A análise feita Xu, Ma e LV (2016) pontua os conflitos e dificuldades de gestão da transposição das águas das regiões doadoras para as receptoras. Os autores recomendam a criação de um órgão global de tomadores de decisão, que seria crucial para o aprimoramento das estratégias de formulação e implementação de ações emergenciais em caso de seca extrema, pois levaria em consideração todos os interesses envolvidos.

No caso do projeto de integração da bacia do rio São Francisco, fica evidente que o sistema de governança que garanta a distribuição da água de forma equitativa e eficiente, e com sustentabilidade ambiental ainda precisa ser melhor discutido. As previsões de diminuição de disponibilidade de água em decorrência das mudanças climáticas aumenta a urgência do debate. Ainda que o Decreto 5.995 (BRASIL, 2006) tenha feito uma boa descrição de como deve o sistema de gestão do projeto deva funcionar, verifica-se que a não implementação das condições para que a operação seja bem-sucedida. Um exemplo é a falta de informações e clareza sobre o PISF observado entre os administradores dos municípios que deverão ser beneficiados pelo Eixo Leste. 


\section{CONCLUSÕES}

Quanto ao objetivo principal do presente trabalho, que é analisar o Eixo Leste do Projeto de Integração do Rio São Francisco com Bacias Hidrográficas do Nordeste Setentrional no contexto de adaptação às mudanças climáticas, conclui-se que, da maneira como tem sido executado e gerido desde sua inauguração, em março de 2017, a infraestrutura não contribui para a adaptação às mudanças climáticas das populações mais vulneráveis do semiárido.

Em seu primeiro ano de funcionamento, o Eixo Leste do PISF não alcançou sequer um dos seus objetivos básicos, que é distribuir água para as comunidades difusas ao longo do seu trajeto. Esses moradores amarguram um longo ciclo de seca, iniciado em 2012, e continuam dependendo exclusivamente do abastecimento de caminhões-pipa, que não tem regularidade. Sem água para suprir suas demandas básicas, um problema conhecido há décadas e que, segundo o planejamento do PISF, seria combatido, essas populações permanecerão expostas aos efeitos associados às secas, como desemprego rural, fome, pobreza e migrações.

$\mathrm{O}$ aumento de temperatura em mais de $3^{\circ} \mathrm{C}$ já observado em regiões de Pernambuco, fenômeno que se deve em parte às mudanças climáticas (MARENGO et al, 2011), associado às projeções de redução de chuvas no semiárido brasileiro ao longo desse século (IPCC, 2014) e à degradação do solo, contribuem para a desertificação, secas mais severas e longas, o que deixa as populações do semiárido ainda mais vulneráveis.

A ausência da implantação dos sistemas de distribuição de água de uso difuso ao longo do Eixo Leste do PISF, que garantiriam às comunidades o acesso à água transportada pelos canais, conforme o Plano Ambiental 15, ameaça a sobrevivência no local caso perdure o ciclo atual de seca. Esses sistemas de distribuição foram descritos nos Projetos Executivos que detalham as tomadas d'água, que ficou a cargo do DNOCS. Eles prevêem, na maioria dos casos, sistemas de balsas flutuantes que farão a retirada de água diretamente no canal de transposição, que também serão equipados com uma estação de tratamento de água. Em caso de comunidades com até 160 moradores, ou 40 famílias, a água seguirá para um chafariz como estrutura de reservação e abastecimento de água tratada, segundo o acordo assinado entre MI e DNOCS/PE. A rede de distribuição de água tratada será implantada apenas em comunidades onde o número de famílias for maior que 40, ou 160 moradores, desde que as residências estejam agrupadas. 
Ao analisar, portanto, o seu ano inaugural no cenário atual concluiu-se que o modelo em vigor no Eixo Leste do PISF não poderia ser enquadrado como uma medida de adaptação, pois não contribuiu para a permanência daquelas comunidades no semiárido caso o evento climático extremo perdure e os impactos das mudanças climáticas fiquem mais críticos.

Ainda que o PISF não tenha sido concebido claramente como uma medida de adaptação às mudanças climáticas, o projeto teria potencial para exercer essa função. A justificativa oficial para implantação do PISF se enquadra na explanação de Füssel (2007a), que afirma que a discussão sobre a necessidade de adaptação normalmente surge a partir de experiências com eventos extremos, quando esses fenômenos expõem a vulnerabilidade da região ou população afetada, que podem ser provocados pela variabilidade climática e mudanças climáticas. E o PISF se define como um projeto de infraestrutura hídrica numa região marcada por irregularidade de chuvas, o que causa "escassez de água, associada à incerteza climática e mantém limitadas as atividades humanas básicas, o abastecimento das populações e o desenvolvimento das atividades agrícolas e industriais" (MINISTÉRIO DA INTEGRAÇÃO NACIONAL, 2004, p. 59).

O PISF, portanto, poderia ser visto como um processo de adaptação iniciado por um agente público, com um propósito planejado e antecipatório para combater a insegurança hídrica no semiárido, que sofre de reconhecida variabilidade climática e é classificado como uma das zonas mais vulneráveis às mudanças climáticas.

É possível que, ao ajustar suas falhas e reconhecer que as populações difusas do semiárido são as mais vulneráveis às mudanças climáticas, o PISF exerça esse potencial. Para tanto, o projeto teria que concluir suas obras complementares para dar a capilaridade à distribuição das águas do São Francisco. Isso inclui não apenas a implementação dos sistemas de uso difuso, destinado às comunidades rurais ao longo do Eixo Leste, mas também as adutoras e ramais previstos no projeto, como o Ramal do Agreste, derivação de 71 quilômetros a partir do reservatório de Barro Branco do PISF.

Por outro lado, o extenso levantamento feito nesse trabalho mostrou que, mesmo que todos os sistemas de distribuição de uso difuso sejam implantados como o planejado nos respectivos Projetos Executivos, a água do Eixo Leste não atenderá à totalidade das comunidades rurais nos municípios por onde passa. 
Em Floresta (PE), a água da transposição atenderia $17 \%$ da população rural do município; em Betânia (PE) esse atendimento seria de 8,7\%; em Custódia (PE) seria de 48\%; em Sertânia (PE) a água do Eixo Leste chegaria a 33,7\% da população rural estimada. A água do Eixo Leste atenderia em maior proporção a população rural de Monteiro (PB), com uma cobertura de $80,3 \%$.

Se não contribuiu para a adaptação das populações rurais difusas, a água que correu pelo Eixo Leste no período teve o objetivo de abastecer principalmente a maior cidade do interior da Paraíba, Campina Grande.

O município depende do reservatório Epitácio Pessoa (Boqueirão), que atingiu seus níveis mais baixos com o ciclo de estiagem observado a partir de 2012, e também esteve à beira do colapso. Campina Grande, que tem o segundo maior PIB do estado da Paraíba, concentra um polo industrial importante, fonte de $20 \%$ das riquezas geradas na cidade (IDEME, 2016). Essa observação vai ao encontro do trabalho de Brito (2013), que mostrou que a decisão de construir o Eixo Leste como parte do PISF pode ter sido tomada com o objetivo de assegurar o abastecimento de Campina Grande. Por outro lado, o autor não aborda o contexto político em que essa deliberação ocorreu.

Dessa maneira, as comunidades rurais difusas distribuídas ao longo do Eixo Leste não foram priorizadas nesse primeiro ano de funcionamento. Muitos moradores, limitados a verem a água passar pelos canais, encontraram meios de retirar o recurso natural de forma clandestina. Logo, conclui-se que a delonga da implementação dos sistemas de distribuição a essas comunidades compromete os principais objetivos do PISF e do PBA 15, dentre eles: melhorias das condições de vida das comunidades rurais posicionadas ao longo dos canais da transposição e vítimas de abastecimento hídrico precário, segurança hídrica e água de boa qualidade, redução de riscos sociais, sanitários e econômicos ligados a possíveis retiradas ilegais ou clandestinas dos canais e reservatórios que formam o PISF.

Por não discutir abertamente no RIMA (MINISTÉRIO DA INTEGRAÇÃO NACIONAL, 2004) os impactos das mudanças climáticas no semiárido brasileiro e sobre seus recursos hídricos no contexto do projeto, os executores do PISF contribuem para que o debate não seja abordado com profundidade na esfera pública e retarda a incorporação de medidas de adaptação no planejamento de obras de infraestrutura hídrica. 
Ao não abordar a questão no âmbito do PISF, os executores colaboram ainda para a desinformação entre usuários das bacias doadora e receptora, que não são estimulados a planejar o uso da água considerando os impactos das mudanças climáticas sobre o recurso natural e sobre o ambiente em geral. Da mesma forma, contribui para a desorientação dos órgãos encarregados de gerir o Eixo Leste do PISF.

Para que que medidas planejadas de adaptação climática tenham o efeito esperado, são sugeridas ações contínuas, baseadas em informações sobre as condições climáticas futuras, em um planejamento que inclua aspectos específicos da região, incluindo sociais. Nenhuma opção tem chance de funcionar em um ambiente que não esteja preparado, não tenha capacidade ou não queira receber a medida em questão (KLEIN, 2003; FÜSSEL, 2007a). Nas cidades dos estados de Pernambuco e Paraíba que estão no trajeto do Eixo Leste, a falta de informação sobre o funcionamento e distribuição do PISF são evidentes, o que coloca em risco o atendimento dos objetivos primários do projeto.

Quanto ao objetivo específico que visava compreender os processos decisórios e de governança em torno da disponibilização do recursos hídricos no domínio do projeto, pode-se dizer que ele foi parcialmente alcançado. Isso se deve ao fato de a estrutura de governança proposta pelo Decreto 5.995, publicado em 2006, não ter sido implementada em sua totalidade.

O termo de compromisso assinado entre União e estados beneficiados ainda não foi efetivado, mesmo depois de um ano de funcionamento do Eixo Leste do PISF. A ausência de uma operadora federal nesse primeiro ano fragiliza a operação, pois dificulta uma ação integrada e sustentável, assim como a fiscalização de outorga e de prazos para entrega dos sistemas de distribuição de uso difuso. Embora a Codevasf tenha sido designada pelo governo federal para operar o PISF, essa não assumiu suas tarefas. Há um vazio de responsabilidades na gestão da distribuição. Também é de conhecimento que o Ministério da Integração Nacional manifestou interesse em privatizar as atividades de distribuição e operação do sistema.

Conclui-se, portanto, que ainda é necessário um conjunto de fatores para um projeto de infraestrutura hídrica desse porte e numa região semiárida seja exitoso. Embora o CBHSF integre o Conselho Gestor, ainda não é clara como será a sua efetiva participação no processo decisório. A organização dos usuários das bacias receptoras ainda se 
mostra incipiente e difusa, observando-se a marginalização dos usuários moradores de comunidades rurais no processo.

Ainda em termos de governança, pode-se concluir que, com o repasse da responsabilidade da implantação desses sistemas do governo federal para órgãos estaduais, a efetividade da operação do PISF fica ameaçada, já que essas entidades dispõem de menor corpo técnico e orçamento, o que pode contribuir para a demora da implantação dos sistemas de uso difuso.

Mesmo após a conclusão das obras da transposição, as variáveis climáticas/hidrológicas continuarão exercendo influência, o que torna o conhecimento de suas causas e a adaptação ainda mais necessárias. A efetividade do PISF, portanto, será um indicativo de como o Brasil articula e implementa políticas públicas e medidas de intervenção para promover a adaptação de populações vulneráveis. Segundo postula Füssel (2007a), medidas de adaptação terão o efeito esperado desde que se considere que elas não se encerram num período delimitado, mas são contínuas, e que informações precisas sobre as condições climáticas futuras reduzem consideravelmente o custo total da adaptação.

Discutir a gestão do PISF e sua distribuição de água como medida de adaptação às mudanças climáticas seria uma oportunidade excepcional de aplicação do Plano Nacional de Adaptação à Mudança do Clima estabelecido pelo governo brasileiro. Esse tem o objetivo de oferecer orientação técnica e política para as ações que visam reduzir riscos climáticos frente aos efeitos associados à mudança do clima. A gestão do PISF e sua distribuição de água como medida de adaptação possibilitaria o cumprimento dos objetivos específicos do Plano Nacional, a saber ampliação e disseminação do conhecimento científico, técnico e tradicional; produção, gestão e disseminação de informação sobre o risco climático; coordenação e cooperação entre órgãos públicos e a sociedade civil; identificação e proposição de medidas para promover a adaptação e a redução do risco climático.

Da mesma forma, a gestão do PISF e sua distribuição de água como medida de adaptação às mudanças climáticas seria uma oportunidade de aplicação da Política Estadual de Enfrentamento às Mudanças Climáticas de Pernambuco. Tal política definiu a adaptação como um conjunto de iniciativas e estratégias que permitem a adaptação, nos sistemas naturais criados ou pelos homens, a um novo ambiente, em resposta à mudança do clima atual ou esperada. No que se refere aos recursos hídricos em específico, a Política Estadual prevê a 
definição de áreas de maior vulnerabilidade, assim como implantação de medidas de mitigação e adaptação em função das mudanças climáticas visando a garantia de água em qualidade e quantidade para uso múltiplo. A gestão do PISF como medida de adaptação, portanto, poderia também ser vista como aplicação dessa política do estado de Pernambuco, onde o Eixo Leste do PISF tem sua maior extensão e maior número de comunidades rurais previstas para serem atendidas.

\subsection{RECOMENDAÇÕES PARA ESTUDOS FUTUROS}

Para os próximos trabalhos referentes ao tema, sugere-se o aprofundamento de estudos hidrológicos na bacia do rio São Francisco com dados atualizados. Afinal, como se sabe, o nível do reservatório de Sobradinho condiciona a vazão a ser transferida pelos eixos Norte e Leste e, se não houver água suficiente, todo o PISF perde sua função. Os estudos seriam importantes para se prever a disponibilidade hídrica da bacia doadora do PISF, o que poderia indicar em quais condições a transferência de água pelos eixos ficaria impossibilitada. Dessa forma, o sistema de governança seria fortalecido ao ter à sua disposição dados mais atualizados para fazer um melhor planejamento da distribuição de água, prevenir conflitos entre as bacias doadora e receptora e ajudar a fazer um uso planejado do recurso disponível.

Análises de custo-benefício do PISF também são importantes e podem servir como base para tomadas de decisão futuras. Sabe-se que medidas de adaptação às mudanças climáticas serão imprescindíveis, o que pode demandar obras de infraestrutura hídrica de grande porte. $\mathrm{O}$ modelo adotado no PISF, portanto, pode auxiliar no planejamento. Não foi possível realizar uma análise de custo-benefício no presente trabalho devido à dificuldade de se obter dados confiáveis referentes aos custos do projeto. Há estimativas que variam entre R $\$ 10$ bilhões e R $\$ 30$ bilhões.

Recomenda-se também estudos que discutam como projeções relacionadas aos impactos das mudanças climáticas possam ser incorporadas no planejamento de obras de infraestrutura hídrica. Esse trabalho reconhece a complexidade do tema, que envolve questões interdisciplinares. Porém, reforça que o debate deve ser aprofundado a fim de que obras e políticas públicas sejam planejadas para se evitar desperdício de dinheiro público e contribuam para a adaptação das populações mais vulneráveis às mudanças climáticas. 


\section{REFERÊNCIAS BIBLIOGRÁFICAS}

AGÊNCIA NACIONAL DE ÁGUAS. Resolução no 411, de 22 de Setembro de 2005. ANA, 2005.

AGÊNCIA NACIONAL DE ÁGUAS. Conjuntura dos recursos hídricos no Brasil: regiões hidrográficas brasileiras. Brasília: ANA, 2015.

AZEVEDO, L.G.T. Integração de Bacias Hidrográficas. In: Centro de Gestão e Estudos Estratégicos (Brasil). A Questão da Água no Nordeste / Centro de Gestão e Estudos Estratégicos, Agência Nacional de Águas. Brasília, DF: CGEE, 2012. p. 333-372.

BAHIA, C. M. O Projeto da integração do rio São Francisco às bacias do Nordeste Setentrional e a Lei n. 9433/1997. Relatório técnico. 2006. 22 p.

BHASKAR, R. Reclaiming reality: A critical introduction to contemporary philosophy. Taylor \& Francis, 2010.

BASSETT, T. J.; FOGELMAN, C. Déjà vu or something new? The adaptation concept in the climate change literature. Geoforum, v. 48, p. 42-53, 2013.

BETTENCOURT, P. et al. Plano de recursos hídricos da bacia hidrográfica do rio São Francisco. Recursos Hídricos, v. 37, n. 1, 2016.

BLUNDEN, J.; ARNDT, D. S. State of the Climate in 2015. Bulletin of the American Meteorological Society, v. 97, n. 8, p. Si-S275, 2016.

BRASIL. Lei no 9.433, de 8 de janeiro de 1997. Disponível em: <http://www.planalto.gov.br/ ccivil_03/leis/L9433.htm\#>

- Ministério da Integração Nacional/ SDR. Relatório final do grupo de trabalho interministerial para redelimitação do semiárido nordestino e do polígono das secas. Ministério de Integração Nacional. Brasília, DF, 2005.

. Decreto s7n, de 5 de Junho de 2001. Disponível em: <http://www.planalto.gov.br/ ccivil_03/dnn/2001/dnn9223.htm>

- Decreto $\mathrm{n}^{\mathrm{o}}$ 5.995, de 19 de Dezembro de 2006. Disponíve em: < $\underline{\mathrm{https}: / /}$ www.lexml.gov.br/urn/urn:lex:br:federal:decreto:2006-12-19;5995>

. Plano Nacional sobre Mudança do Clima - PNMC. Brasil. Brasília, Decreto n.6.263 de 21 de novembro de 2007, 2008. Disponível em <http://www.mma.gov.br/estruturas/ smcq_climaticas/_arquivos/plano_nacional_mudanca_clima.pdf $>$. Acesso em: 07 mar. 2017. 
. Lei n.12.187, de 29 de dezembro de 2009. Institui a Política Nacional sobre Mudança do Clima - PNMC e dá outras providências. Diário Oficial da União, Brasília, Seção 1, Edição Extra, p.109-10, 2009.

Plano Nacional de Adaptação à Mudança do Clima: sumário executivo/Ministério do Meio Ambiente. Brasília, MMA, 2016.

BRITO, F.B.D. Conflitos pelo acesso e uso da água: integração do rio São Francisco com a Paraíba (Eixo Leste). 2013. 370 f. Tese (Doutorado em Geografia) - Instituto de Geociências, Universidade Federal do Rio Grande do Sul, Porto Alegre, 2013.

BROOKS, N. Vulnerability, risk and adaptation: A conceptual framework. Tyndall Centre for Climate Change Research Working Paper, v. 38, 1-16. 2003.

CAMPOS, J. N. B. Águas superficiais no semiárido brasileiro: desafios ao atendimento aos usos múltiplos. In: MEDEIROS, S. S. Recursos hídricos em regiões áridas e semiáridas. Campina Grande: Instituto Nacional do Semiárido, 2011. p. 250-268.

CARTER, T. R. et al. IPCC technical guidelines for assessing climate change impacts and adaptations: part of the IPCC special report to the first session of the conference of the parties to the UN framework convention on climate change. London, 1994.

CAÚLA, BQ, MOURA GB. Aspectos ambientais e jurídicos da transposição do Rio São Francisco. III Encontro da ANPPAS, v. 23, p.331, 2006.

CENTRO DE GESTÃo e estudos eStratÉGiCOS (BRASIL). A Questão da Água no Nordeste / Centro de Gestão e Estudos Estratégicos, Agência Nacional de Águas. Brasília, DF: CGEE, 2012.

CHOU, S. C. et al. Assessment of climate change over South America under RCP 4.5 and 8.5 downscaling scenarios. American Journal of Climate Change, v. 3, n. 5, p. 512-525, 2014.

COMITÊ DA BACIA HIDROGRÁFICA DO RIO SÃO FRANCISCO. Plano Decenal de Recursos Hídricos da Bacia do rio São Francisco 2004-2013 (PBHSF). Salvador. 337p. 2004

COMITÊ DE BACIA HIDROGRÁFICA DO RIO SÃO FRANCISCO. 2016: 15 anos do CBHSF, 515 anos do Rio São Francisco. 195 p. 2016.

CONSÓRCIO ECOPLAN-SKILL. Projeto de Integração do Rio São Francisco com Bacias Hidrográficas do Nordeste Setentrional - Eixo Leste; Projeto Executivo do Lote D. Relatório Final do Projeto Executivo das Obras Complementares. Porto Alegre. 164 p. 2011. 
CONSÓRCIO ECOPLAN-SKILL. Projeto de Integração do Rio São Francisco com Bacias Hidrográficas do Nordeste Setentrional - Eixo Leste; Projeto Executivo do Lote D. Minuta do Relatório Final dos Projetos Executivos, Volume 2 - Anexos / Anexo II - Lote 12 / Tomo C - Barragens. Porto Alegre. 682 p. 2014.

CONSÓRCIO TECHNE-PROJETEC-BRLi. Projeto de Integração do Rio São Francisco com Bacias Hidrográficas do Nordeste Setentrional - Eixo Leste; Projeto Executivo do Lote C. Relatório Final dos Projetos Executivos das Barragens. Recife. 228 p. 2012.

CONSÓRCIO PROJETEC/ENGESOFT. Elaboração dos Projetos Básicos da Infraestrutura de Abastecimento de Água das Comunidades Diretamente Afetadas com a Implantação do Projeto de Integração do Rio São Francisco com Bacias Hidrográficas do Nordeste Setentrional (PISF), 174p. SISTEMA AGROVILAS, RELATÓRIO 3B, RELATÓRIO GERAL. Recife, 2014a.

Elaboração dos Projetos Executivos da Infraestrutura de Abastecimento de Água das Comunidades Diretamente Afetadas com a Implantação do Projeto de Integração do Rio São Francisco com Bacias Hidrográficas do Nordeste Setentrional (PISF), 98 p. PROJETOS EXECUTIVOS, Sistema Angicos, Relatório 3B, Volume 2. Recife, 2014b.

Elaboração dos Projetos Executivos da Infraestrutura de Abastecimento de Água das Comunidades Diretamente Afetadas com a Implantação do Projeto de Integração do Rio São Francisco com Bacias Hidrográficas do Nordeste Setentrional (PISF), 112 p. PROJETO EXECUTIVO, Sistema Pedro Jorge/Lajedo, Relatório 3B, Volume 3. Recife, 2014c.

Elaboração dos Projetos Executivos da Infraestrutura de Abastecimento de Água das Comunidades Diretamente Afetadas com a Implantação do Projeto de Integração do Rio São Francisco com Bacias Hidrográficas do Nordeste Setentrional (PISF), 84 p. PROJETOS EXECUTIVOS, Sistema Roça Velha, Relatório 3B, Volume 4. Recife, 2014d.

Elaboração dos Projetos Básicos da Infraestrutura de Abastecimento de Água das Comunidades Diretamente Afetadas com a Implantação do Projeto de Integração do Rio São Francisco com Bacias Hidrográficas do Nordeste Setentrional (PISF), 145p. PROJETOS EXECUTIVOS, Sistemas Serra Branca, Relatório 3B, Volume 10. Recife, 2014e.

Elaboração dos Projetos Executivos da Infraestrutura de Abastecimento de Água das Comunidades Diretamente Afetadas com a Implantação do Projeto de Integração do Rio São Francisco com Bacias Hidrográficas do Nordeste Setentrional (PISF). 82 p. PROJETOS EXECUTIVOS, Sistema Riacho do Mel, Relatório 3B, Volume 11. Recife, 2014f. 
. Elaboração dos Projetos Executivos da Infraestrutura de Abastecimento de Água das Comunidades Diretamente Afetadas com a Implantação do Projeto de Integração do Rio São Francisco com Bacias Hidrográficas do Nordeste Setentrional (PISF). 82 p. PROJETOS EXECUTIVOS, Sistema Baixa, Relatório 3B, Volume 11. Recife, $2014 \mathrm{~g}$.

Elaboração dos Projetos Executivos da Infraestrutura de Abastecimento de Água das Comunidades Diretamente Afetadas com a Implantação do Projeto de Integração do Rio São Francisco com Bacias Hidrográficas do Nordeste Setentrional (PISF). 243 p. PROJETOS EXECUTIVOS, Sistema Samambaia, Relatório 3B, Volume 2. Recife, 2014h.

. Elaboração dos Projetos Básicos da Infraestrutura de Abastecimento de Água das Comunidades Diretamente Afetadas com a Implantação do Projeto de Integração do Rio São Francisco com Bacias Hidrográficas do Nordeste Setentrional (PISF). 162 p. PROJETOS EXECUTIVOS, Sistema Carvalho/Lagoa da Onça, Relatório 3B, Volume 12. Recife, 2014i.

. Elaboração dos Projetos Executivos da Infraestrutura de Abastecimento de Água das Comunidades Diretamente Afetadas com a Implantação do Projeto de Integração do Rio São Francisco com Bacias Hidrográficas do Nordeste Setentrional (PISF). 128 p. PROJETOS EXECUTIVOS, Sistema Barro Vermelho, Relatório 3B, Volume 2. Recife, $2014 \mathrm{j}$.

Elaboração dos Projetos Executivos da Infraestrutura de Abastecimento de Água das Comunidades Diretamente Afetadas com a Implantação do Projeto de Integração do Rio São Francisco com Bacias Hidrográficas do Nordeste Setentrional (PISF). 109 p. PROJETOS EXECUTIVOS, Sistema Favela, Relatório 3B, Volume 13. Recife, 20141.

. Elaboração dos Projetos Básicos da Infraestrutura de Abastecimento de Água das Comunidades Diretamente Afetadas com a Implantação do Projeto de Integração do Rio São Francisco com Bacias Hidrográficas do Nordeste Setentrional (PISF). 109 p. PROJETOS BÁSICOS, Sistema Rio da Barra, Relatório 2B, Volume 17. Recife, 2014m.

Elaboração dos Projetos Executivos da Infraestrutura de Abastecimento de Água das Comunidades Diretamente Afetadas com a Implantação do Projeto de Integração do Rio São Francisco com Bacias Hidrográficas do Nordeste Setentrional (PISF). 114 p. PROJETOS EXECUTIVOS, Sistema Maxixe, Relatório 3B, Volume 2. Recife, $2014 n$.

Elaboração dos Projetos Executivos da Infraestrutura de Abastecimento de Água das Comunidades Diretamente Afetadas com a Implantação do Projeto de Integração do Rio São Francisco com Bacias Hidrográficas do Nordeste Setentrional (PISF). 53 p. PROJETOS EXECUTIVOS, Sistema Jaramatáia, Relatório 3B, Volume 33. Recife, 2015a. 
CONSÓRCIO PROJETEC/ENGESOFT. Elaboração dos Projetos Executivos da Infraestrutura de Abastecimento de Água das Comunidades Diretamente Afetadas com a Implantação do Projeto de Integração do Rio São Francisco com Bacias Hidrográficas do Nordeste Setentrional (PISF). 102 p. ESTUDOS EXECUTIVOS, Sistema Malhadinha, Relatório 3B, Volume 23. Recife, $2015 \mathrm{~b}$.

Elaboração dos Projetos Executivos da Infraestrutura de Abastecimento de Água das Comunidades Diretamente Afetadas com a Implantação do Projeto de Integração do Rio São Francisco com Bacias Hidrográficas do Nordeste Setentrional (PISF), 133 p. PROJETOS EXECUTIVOS Sistema Jequeri, Relatório 3B, Volume 22. Recife, 2015c.

Elaboração dos Projetos Executivos da Infraestrutura de Abastecimento de Água das Comunidades Diretamente Afetadas com a Implantação do Projeto de Integração do Rio São Francisco com Bacias Hidrográficas do Nordeste Setentrional (PISF). 125 p. PROJETOS EXECUTIVOS, Sistema Cipó, Relatório 3B, Volume 21. Recife, 2015 d.

Elaboração dos Projetos Executivos da Infraestrutura de Abastecimento de Água das Comunidades Diretamente Afetadas com a Implantação do Projeto de Integração do Rio São Francisco com Bacias Hidrográficas do Nordeste Setentrional (PISF). 50 p. PROJETOS EXECUTIVOS, Sistema Passagem de Pedra, Relatório 3B, Volume 30. Recife, $2015 \mathrm{e}$.

Elaboração dos Projetos Executivos da Infraestrutura de Abastecimento de Água das Comunidades Diretamente Afetadas com a Implantação do Projeto de Integração do Rio São Francisco com Bacias Hidrográficas do Nordeste Setentrional (PISF). 120 p. PROJETOS EXECUTIVOS, Sistema Pernambuquinho, Relatório 3B, Volume 32. Recife, $2015 \mathrm{f}$.

Elaboração dos Projetos Executivos da Infraestrutura de Abastecimento de Água das Comunidades Diretamente Afetadas com a Implantação do Projeto de Integração do Rio São Francisco com Bacias Hidrográficas do Nordeste Setentrional (PISF). 143 p. PROJETOS EXECUTIVOS, Sistema Rigideira, Relatório 3B, Volume 24. Recife, 2015g.

Elaboração dos Projetos Executivos da Infraestrutura de Abastecimento de Água das Comunidades Diretamente Afetadas com a Implantação do Projeto de Integração do Rio São Francisco com Bacias Hidrográficas do Nordeste Setentrional (PISF). 168 p. ESTUDOS EXECUTIVOS, Sistema Bom Jesus, Relatório 3B, Volume 27. Recife, $2015 \mathrm{~h}$. 
CONSÓRCIO PROJETEC/ENGESOFT. Elaboração dos Projetos Executivos da Infraestrutura de Abastecimento de Água das Comunidades Diretamente Afetadas com a Implantação do Projeto de Integração do Rio São Francisco com Bacias Hidrográficas do Nordeste Setentrional (PISF). 168 p. ESTUDOS EXECUTIVOS, Sistema Sítio do Meio, Relatório 3B, Volume 26. Recife, $2015 \mathrm{i}$

Elaboração dos Projetos Executivos da Infraestrutura de Abastecimento de Água das Comunidades Diretamente Afetadas com a Implantação do Projeto de Integração do Rio São Francisco com Bacias Hidrográficas do Nordeste Setentrional (PISF). 138 p. PROJETOS EXECUTIVOS, Sistema Rigideira, Relatório 3B, Volume 25 Recife, 2015j.

. Elaboração dos Projetos Básicos da Infraestrutura de Abastecimento de Água das Comunidades Diretamente Afetadas com a Implantação do Projeto de Integração do Rio São Francisco com Bacias Hidrográficas do Nordeste Setentrional (PISF). 56 p. ESTUDOS BÁSICOS, Sistema Espírito Santo, Relatório 3B, Volume 28. Recife, 20151.

Elaboração dos Projetos Executivos da Infraestrutura de Abastecimento de Água das Comunidades Diretamente Afetadas com a Implantação do Projeto de Integração do Rio São Francisco com Bacias Hidrográficas do Nordeste Setentrional (PISF). 61 p. PROJETOS EXECUTIVOS, Sistema Pocinhos, Relatório 3B, Volume 31. Recife, $2015 \mathrm{~m}$.

Elaboração dos Projetos Executivos da Infraestrutura de Abastecimento de Água das Comunidades Diretamente Afetadas com a Implantação do Projeto de Integração do Rio São Francisco com Bacias Hidrográficas do Nordeste Setentrional (PISF). 73 p. PROJETOS EXECUTIVOS, Sistema Cachoeirinha, Relatório 3B, Volume 29. Recife, 2015n.

CORNELL, S.; PARKER, J. Critical realist interdisciplinarity. Interdisciplinarity and climate change, Routledge, p. 25-34, 2010.

CRESWELL, J.W. Research design: Qualitative, quantitative, and mixed methods approaches. 4th ed.. Sage publications, 2014. 304 p.

DE ANDRADE, J.G.P. et al. Interbasin water transfers: the Brazilian experience and international case comparisons. Water resources management, v. 25, n.8, p. 1915-1934, 2011.

DE JONG, P. et al. Hydroelectric production from Brazil's São Francisco River could cease due to climate change and inter-annual variability. Science of The Total Environment, v. 634, p. 1540-1553, 2018.

EMPINOTTI, V. L. E se eu não quiser participar? O caso da não participação nas eleições do comitê de bacia do rio São Francisco. Ambiente \& Sociedade, v. 14, n. 1, p. 195-211, 2011. 
FEENSTRA, J. F. Handbook on methods for climate change impact assessment and adaptation strategies. 1998 .

FÜSSEL, H. M. Adaptation planning for climate change: concepts, assessment approaches, and key lessons. Sustainability science, v. 2, n. 2, p. 265-275, 2007. (a)

FÜSSEL, H. M. Vulnerability: generally applicable conceptual framework for climate change research. Global Environmental Change 17. no. 2, p 155-167. 2007.(b)

GOHARI, A, et al. Water transfer as a solution to water shortage: a fix that can backfire. Journal of Hydrology 491,2013, p 23-39.

HENKES, S.L. A política, o direito e o desenvolvimento: um estudo sobre a transposição do rio São Francisco. Revista Direito GV. v. 10, n. 2. p. 497. 2014.

HUTCHINSON, C. F.; VARADY, R. G.; DRAKE, S. Old and new: Changing paradigms in arid lands water management. In: Water and Sustainability in Arid Regions. Springer, Dordrecht, 2010. p. 311-332.

INSTITUTO DE DESENVOLVIMENTO MUNICIPAL E ESTADUAL. Produto Interno Bruto dos Municípios do Estado da Paraíba 2014. João Pessoa: Governo do Estado da Paraíba: IDEME, 2016.

IPCC. Climate Change 2014: Synthesis Report. Contribution of Working Groups I, II and III to the Fifth Assessment Report of the Intergovernmental Panel on Climate Change [Core Writing Team, R.K. Pachauri and L.A. Meyer (eds.)]. IPCC, Geneva, Switzerland, 2014. 151 p.

JACOBI, P. R. et al. Governança ambiental e economia verde. Ciência \& Saúde Coletiva, v. 17, n. 6, p. 1469-1478, 2012.

JACOBI, P. R.; BARBI, F. Democracia e participação na gestão dos recursos hídricos no Brasil. Revista Katálysis, v. 10, n. 2, p. 237-244, 2007.

JONES, R., BOER, R. Assessing current climate risks Adaptation Policy Framework: A Guide for Policies to Facilitate Adaptation to Climate Change. UNDP, 2003. Disponível em $<$ http://www.undp.org/cc/apf-outline.htm>.

KATES, R. W. Cautionary tales: adaptation and the global poor. In: Societal adaptation to climate variability and change. Springer Netherlands, 2000. p. 5-17.

KLEIN, R. J. T. Adaptation to climate variability and change: what is optimal and appropriate. Climate Change in the Mediterranean: Socio-Economic Perspectives of Impacts, Vulnerability and Adaptation, v. 32, 2003. 
LEITE, J. C. F.; SOUZA, K. L. D. O novo perfil do Nordeste Brasileiro no censo demográfico 2010. Fortaleza: Banco do Nordeste do Brasil, 2012.

LIM, B. et al. Adaptation policy frameworks for climate change: developing strategies, policies and measures. 2005.

MAGRIN, G. O. et al. Central and South America. Climate change, p. 1499-1566, 2014.

MARENGO, J.A. Mudanças climáticas globais e seus efeitos sobre a biodiversidade: caracterização do clima atual e definição das alterações climáticas para o território brasileiro ao longo do século XXI. Brasília: MMA, 2006. 212p.

MARENGO, J. A. et al. Variabilidade e mudanças climáticas no semiárido brasileiro. In: MEDEIROS, S. S. Recursos hídricos em regiões áridas e semiáridas. Campina Grande: Instituto Nacional do Semiárido, 2011. p. 384-422.

MARENGO, J. A. et al. Development of regional future climate change scenarios in South America using the Eta CPTEC/HadCM3 climate change projections: climatology and regional analyses for the Amazon, São Francisco and the Paraná River basins. Climate Dynamics, v. 38, n. 9-10, p. 1829-1848, 2012.

MARENGO, J. A.; BERNASCONI, M. Regional differences in aridity/drought conditions over Northeast Brazil: present state and future projections. Climatic change, v. 129, n. 1-2, p. 103-115, 2015.

MARENGO, J.A.; CUNHA, A.P.; ALVES L.M. A seca de 2012-15 no semiárido do Nordeste do Brasil no contexto histórico. Climanálise. 2016. p. 3-6.

MARENGO, J. A.; TORRES, R. R.; ALVES, L. M. Drought in Northeast Brazil-past, present, and future. Theoretical and Applied Climatology, v. 129, n. 3-4, p. 1189-1200, 2017.

MEDEIROS, S. S. et al. Recursos hídricos em regiões áridas e semiáridas. Campina Grande: Instituto Nacional do Semiárido, 2011.

MEDEIROS, S. S. et al. Sinopse do censo demográfico para o semiárido brasileiro. Campina Grande: Instituto Nacional do Semiárido, 2012.

MELO, C. R. de. Análise do eixo leste da transposição do Rio São Francisco face aos cenários de uso previstos. 2010. 178 f. Dissertação (Mestrado) - Universidade Federal de Pernambuco. CTG. Programa de Pós-Graduação em Engenharia Civil. Recife. 2010.

MINISTÉRIO DA INTEGRAÇÃO NACIONAL. Relatório de impacto ambiental da transposição. Brasília. 2004. 136 p. 
MINISTÉRIO DA INTEGRAÇÃO NACIONAL. Programa 15. Apoio Técnico para Implantação de Infraestrutura de Abastecimento de Água ao Longo dos Canais. (PBA 15). Brasília. 2005. 17 p.

MOREIRA FILHO, O. Uma transposição de rio esquecida. Revista UFG.v. 8, n. 2, 2006.

NEVES, C.; CARDOSO, A. A experiência internacional com projetos de transposição de água-lições para a do rio São Francisco. XXIX Encontro Nacional de Engenharia de produção. Salvador. 2009.

NOBRE, P. Mudanças climáticas e desertificação: os desafios para o Estado Brasileiro. Desertificação e Mudanças Climáticas no Semiárido Brasileiro. Campina Grande: Instituto Nacional do Semiárido, 2011. p. 25-35.

As origens das águas no Nordeste. In: Centro de Gestão e Estudos Estratégicos

(Brasil). A Questão da Água no Nordeste / Centro de Gestão e Estudos Estratégicos, Agência Nacional de Águas. Brasília, DF: CGEE, 2012. p. 31-43.

NOBRE, P. et al. Impactos de mudanças climáticas globais na hidrologia do semiárido do Nordeste brasileiro para o final do século XXI. In: MEDEIROS, S. S. Recursos hídricos em regiões áridas e semiáridas. Campina Grande: Instituto Nacional do Semiárido, 2011. p. 424-439.

NUNES, CARLOS MOTTA. Projeto de Integração do Rio São Francisco com Bacias Hidrográficas do Nordeste Setentrional - PISF. In: Centro de Gestão e Estudos Estratégicos (Brasil). A Questão da Água no Nordeste / Centro de Gestão e Estudos Estratégicos, Agência Nacional de Águas. Brasília, DF: CGEE, 2012. p. 375-390.

OBERMAIER, M.; ROSA, L.P. Mudança climática e adaptação no Brasil: uma análise crítica. Estudos Avançados, v. 27, n. 78, p. 155-176, 2013.

PBMC. Base científica das mudanças climáticas. Contribuição do Grupo de Trabalho 1 do Painel Brasileiro de Mudanças Climáticas ao Primeiro Relatório da Avaliação Nacional sobre Mudanças Climáticas [Ambrizzi, T., Araujo, M. (eds.)]. COPPE. Universidade Federal do Rio de Janeiro, Rio de Janeiro, 2014. 464 pp.

PERNAMBUCO (estado). Lei No 14.090, de 17 de junho de 2010. Institui a Política Estadual de Enfrentamento às Mudanças Climáticas de Pernambuco e dá outras providências. Diário Oficial Estado de Pernambuco. Disponível em <http://legis.alepe.pe.gov.br/texto.aspx? $\mathrm{id}=28680>$. Acesso em: 24 out. 2017.

PERNAMBUCO (estado). Plano Estadual de Mudanças Climáticas. Recife, PE, 2011. Disponível em <http://www.semas.pe.gov.br/web/semas/planos-de-mudancas-climaticas $>$. Acesso em: 30 ago. 2017.

RAMOS, G. Vidas Secas. São Paulo: Editora Record, 1990. 176 p. 
RANGEL JUNIOR, A. G.; SOUSA, C. M. (Org.). Campina Grande hoje e amanhã. Campina Grande: Universidade Estadual da Paraíba, 2014.

RÊGO, J.C. Parecer técnico sobre a situação do açude Epitácio Pessoa (Boqueirão) e a necessidade de garantir o suprimento hídrico das suas demandas para abastecimento humano. Campina Grande: Comissão Técnica de Assessoramento ao Ministério Público do Estado da Paraíba. 2014. 22 p. Parecer técnico apresentado à Promotoria de Defesa do Consumidor Comarca de Campina Grande, Campina Grande.

RICHARDS, J.; NICHOLLS, R. Handbook on Vulnerability and Adaptation Assessment. In: Vulnerability and Adaptation Assessments Hands-on Training Workshop of the Consultative Group of Experts (CGE) on National Communications from Parties not included in Annex I to the Convention for the Africa Region. 2005.

RODELL, M. et al. Emerging trends in global freshwater availability. Nature, p. 1, 2018.

ROGERS, P.; HALL, Al. W. Effective water governance. Global water partnership, 2003.

SCHIPPER, E. L. F. Conceptual history of adaptation in the UNFCCC process. Review of European, Comparative \& International Environmental Law, v. 15, n. 1, p. 82-92, 2006.

SCHISTEK, H. Caldeirão, Caxio e Cacimba: Três sistemas Tradicionais de Captação de Água de Chuva no Nordeste Brasileiro. In: CONFERÊNCIA INTERNACIONAL DE SISTEMAS DE CAPTAÇÃO DE ÁGUA DE CHUVA. Vol. 9, p. 1-8. 2002.

SILVA, F. L. M. DA; VASCONCELOS, P. B. A relação entre ritmos climáticos e ritmos sociais e produtivos em um projeto de agricultura irrigada. In: ENCONTRO NACIONAL DA ANPEGE, 11., 2015, Presidente Prudente. Anais Eletrônicos...Presidente Prudente. Disponível em $<$ http://www.enanpege.ggf.br/2015/anais/arquivos/23/651.pdf $>$. Acesso em: 15 mar. 2018.

SMIT, B. et al. The science of adaptation: a framework for assessment. Mitigation and adaptation strategies for global change, v. 4, n. 3, p. 199-213, 1999.

SOARES, S. et al. Perfil da pobreza: Norte e Nordeste rurais. International Policy Centre for Inclusive Growth, 2016.

SOUZA FILHO, F. A. A política nacional de recursos hídricos: desafios para sua implantação no semiárido brasileiro. In: MEDEIROS, S. S. Recursos hídricos em regiões áridas e semiáridas. Campina Grande, Instituto Nacional do Semiárido, 2011. p. 1-25.

SUN. T. et al. Water Availability of São Francisco River Basin Based on a Space-Borne Geodetic Sensor. Water. v. 8, n.5, p. 213. 2016. 
THORNTHWAITE, C. W. An approach toward a rational classification of climate. Geographical review, v. 38, n. 1, p. 55-94, 1948.

UBIRATAN GONÇALVES, C., FERNANDES DE OLIVEIRA, C. Rio São Francisco: as águas correm para o mercado. Boletim Goiano de Geografia, v 29, n. 2. 2009.

UNESCO. Proceedings of the International Workshop on Interbasin Water Transfer, 2527 April. Paris, 1999. 229 p.

UNIVERSIDADE DE SÃO PAULO. SISTEMA INTEGRADO DE BIBLIOTECAS DA USP. Diretrizes para apresentação de dissertações e teses da USP : parte I (ABNT) / Sistema Integrado de Bibliotecas da USP ; Vânia Martins Bueno de Oliveira Funaro, coordenadora ; Vânia Martins Bueno de Oliveira Funaro... [et al.]. --3.ed. rev. ampl. mod. - - São Paulo : SIBiUSP, 2016. 100p.

XU, J.; MA, N.; LV, C. Dynamic equilibrium strategy for drought emergency temporary water transfer and allocation management. Journal of Hydrology, 2016.

ZHANG, C. et al. The impacts of climate change on water diversion strategies for a water deficit reservoir. Journal of Hydroinformatics. 2014. p 872-889. 


\section{ANEXOS}

Anexo 1 - Plano de Trabalho original para implantação de infraestrutura de abastecimento de água para comunidades rurais ao longo do PISF assinado entre MI e Compesa

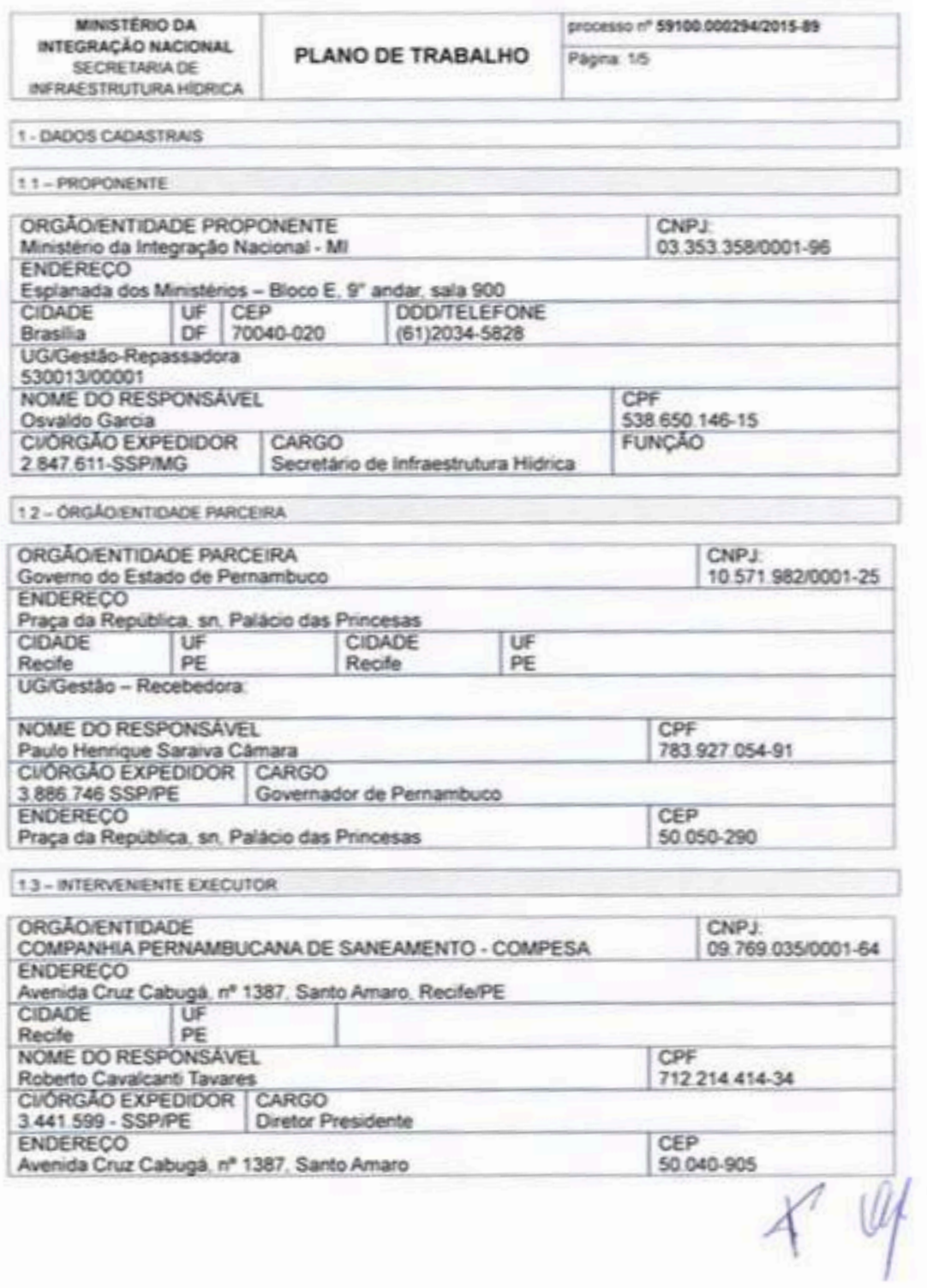




\begin{tabular}{|c|c|c|}
\hline \multirow{2}{*}{ 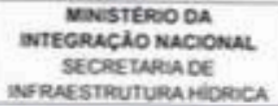 } & \multirow[b]{2}{*}{ PLANO DE TRABALHO } & 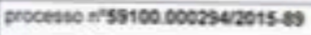 \\
\hline & & Pagna 25 \\
\hline
\end{tabular}

\begin{tabular}{|c|c|c|}
\hline \multicolumn{3}{|l|}{2 - DESCROCLO DO PROAETO } \\
\hline Trevlo do Projeto & \multicolumn{2}{|c|}{ Periodo de Erecucto } \\
\hline 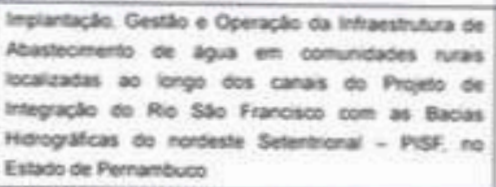 & $\begin{array}{l}\text { Inixio } \\
\text { inseisonots }\end{array}$ & $\begin{array}{l}\text { Temino } \\
24 \text { (vilte e ouato) meies } \\
\text { acbsakfC }\end{array}$ \\
\hline
\end{tabular}

Identileacio do Cointo

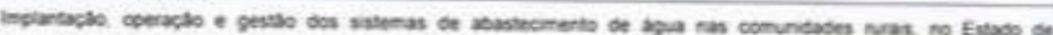

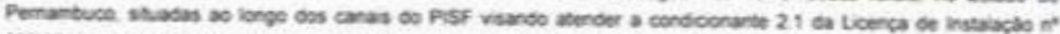

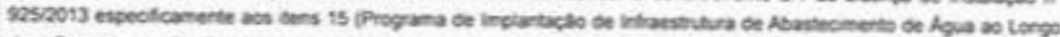

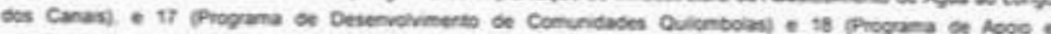

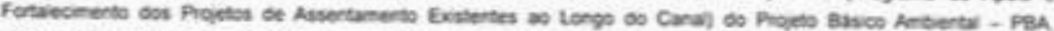

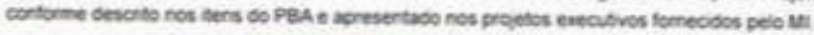

\section{JutEleativa da Proponicio}

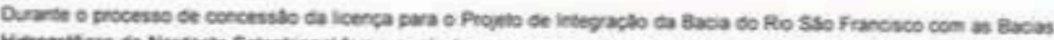

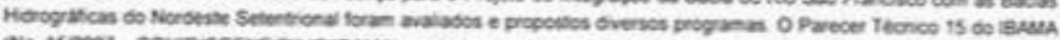

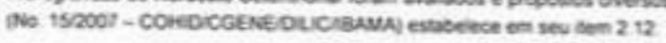

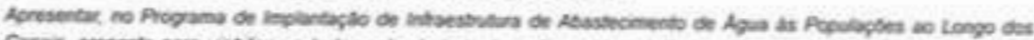

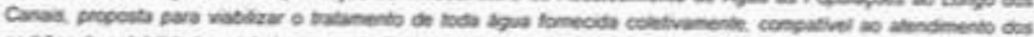

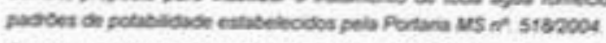

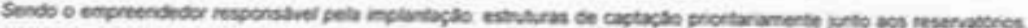

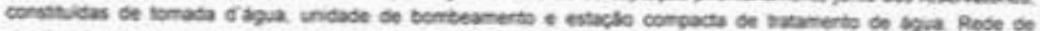

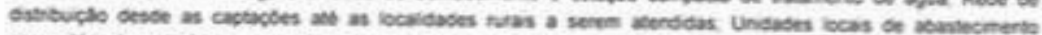

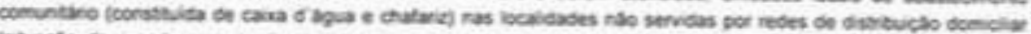

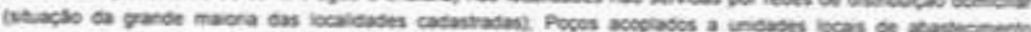

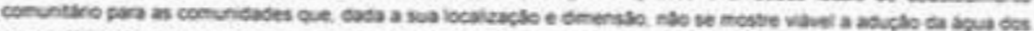

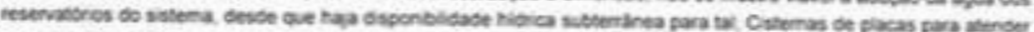
ar pepulactes isolaten

\begin{tabular}{|c|c|c|c|c|}
\hline \multicolumn{5}{|c|}{ 2. PLANO DE APUCACLO (RES 100} \\
\hline \multirow{2}{*}{$\begin{array}{l}\text { Programa de Trabaiho } \\
\text { (Projeta/R Dildade) }\end{array}$} & \multicolumn{2}{|r|}{ Naturra da despess } & \multirow{2}{*}{ Foote } & \multirow[b]{2}{*}{ TOThL } \\
\hline & c6eso & Eapeeifleasto & & \\
\hline te.see . 2051.5900.0020 & 40581 & Cocas e instasecto & 100 & N5 $21.105 .0 \times 55$ \\
\hline resee.2051,12EP0020 & 403051 & Ceras e instaracte & 100 & es $20 \mathrm{cat} \mathrm{res}$ \\
\hline \multicolumn{4}{|c|}{ Total Geral } & os 4t 133192 \\
\hline
\end{tabular}




\begin{tabular}{|c|c|c|}
\hline \multirow{2}{*}{$\begin{array}{l}\text { MENESTERIO DA } \\
\text { INTEGRACR̆O NACIONAL } \\
\text { SECRETARLA DE } \\
\text { INFRESTRUTURA HIOFCA }\end{array}$} & \multirow[b]{2}{*}{ PLANO DE TRABALHO } & processo n'59100.0002942015-99 \\
\hline & & Pagna 35 \\
\hline
\end{tabular}

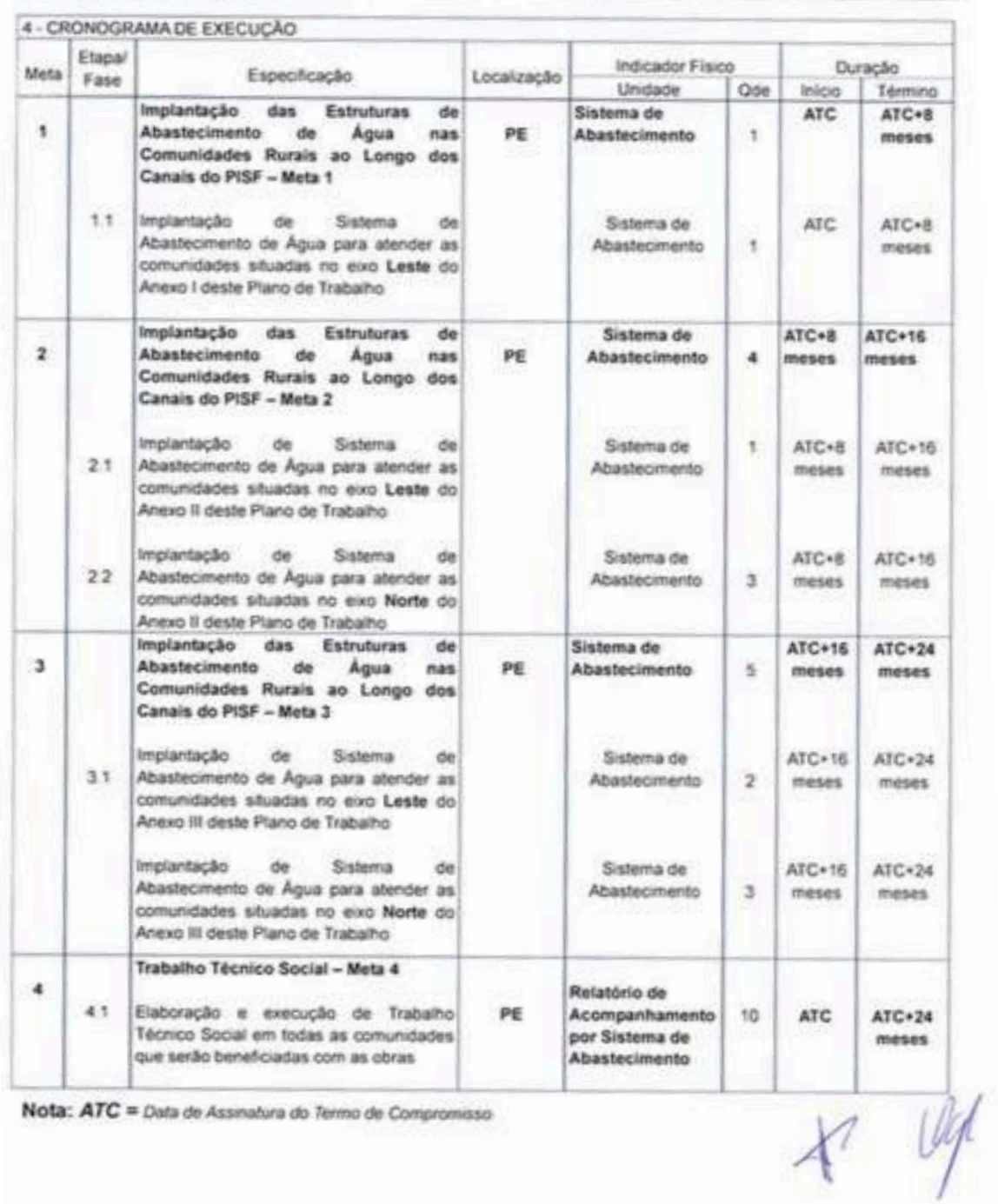


Anexo 2 - Plano de Trabalho original para implantação de infraestrutura de abastecimento de água para comunidades rurais ao longo do PISF assinado entre MI e SARA

\begin{tabular}{|c|c|c|}
\hline \multirow{2}{*}{ 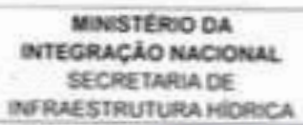 } & \multirow[b]{2}{*}{ PLANO DE TRABALHO } & 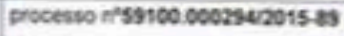 \\
\hline & & Pagna es \\
\hline
\end{tabular}

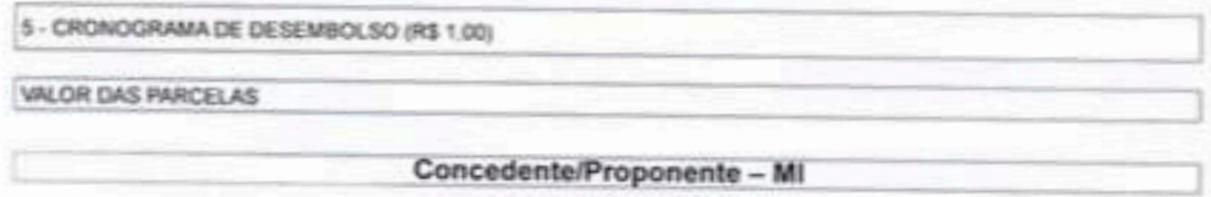

\begin{tabular}{|c|c|c|c|c|c|c|c|c|c|}
\hline Fundenal Arograestca & $\begin{array}{l}\text { Mebancabura } \\
\text { ea Despess }\end{array}$ & T*ues & $\begin{array}{l}z \\
\text { Wists }\end{array}$ & vets & erats & wes & ats & $\begin{array}{c}T^{*} \\
\text { ses }\end{array}$ & vets \\
\hline 18544205159000020 & 4es05: & & & & & & & & \\
\hline 185442051 12EP OCAO & 440051 & 200000200 & & & $2.235: 3010$ & & & & \\
\hline totel & & 2000000 & & & $23 \times 3=10$ & & & & \\
\hline
\end{tabular}

\begin{tabular}{|c|c|c|c|c|c|c|c|c|c|}
\hline Funcerve Programbeca & $\begin{array}{l}\text { Eeta Nutureta } \\
\text { da Dessessa }\end{array}$ & SPAts & 10 ats & ite & $\begin{array}{c}12 \\
\text { vets }\end{array}$ & $\begin{array}{l}13 \\
\text { Nis }\end{array}$ & $\begin{array}{l}10^{2} \\
\text { Nes. }\end{array}$ & Tes. & $\begin{array}{l}18 \\
\text { iets. }\end{array}$ \\
\hline te 544205159000020 & 465051 & & 222312826 & & & & & & \\
\hline 98542051.12600020 & 44505: & & acseseng & & & & & & \\
\hline Total & & & 270010202 & & & & & & \\
\hline
\end{tabular}

\begin{tabular}{|c|c|c|c|c|c|c|c|c|c|}
\hline Funcons Programated & $\begin{array}{c}\text { Aeta Niaturera } \\
\text { da Dencesa }\end{array}$ & $\begin{array}{l}n \pi \\
\text { Nes }\end{array}$ & $\begin{array}{l}18 \\
\text { yts }\end{array}$ & Nes & $\begin{array}{l}20^{\circ} \\
\text { Nes }\end{array}$ & $\begin{array}{l}2 \% \\
\text { Wes }\end{array}$ & $22^{2}$ uts & $\begin{array}{l}23^{\circ} \\
\text { whs }\end{array}$ & $\begin{array}{l}26 \\
\text { Mes }\end{array}$ \\
\hline 1854205158000020 & 4esost & & 58222601 & & & & $1000+0000$ & & \\
\hline 185442051 t26p0020 & Lesos: & & Mastrine & & & & 20000000 & & \\
\hline TOTAL & & & s.minast & & & & $\sec 000 \mathrm{cos}$ & & \\
\hline
\end{tabular}

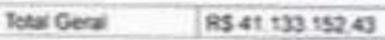

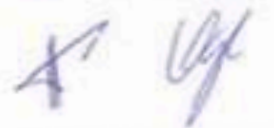

\begin{tabular}{|c|c|c|}
\hline & & 1 \\
\hline $\begin{array}{l}\text { WTEGHAGAO NACIONAL } \\
\text { SECRETARLA DE } \\
\text { INFRAESTRUTURA HIDRACA }\end{array}$ & PLANO DE TRABALHO & Pagna SAs \\
\hline
\end{tabular}
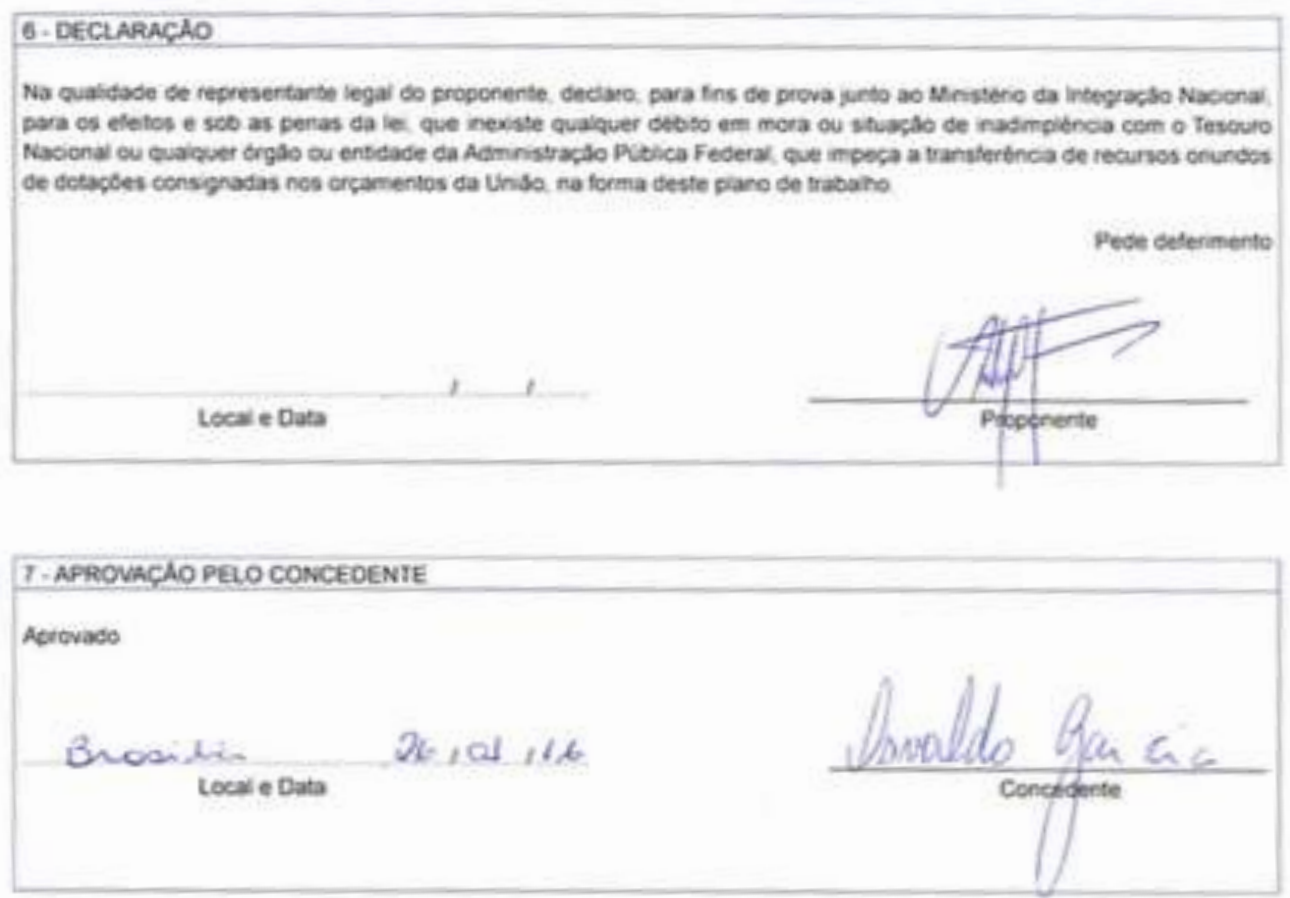


\begin{tabular}{|c|c|c|c|c|c|}
\hline \multirow{2}{*}{\multicolumn{3}{|c|}{ 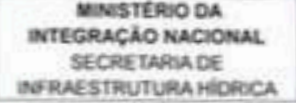 }} & \multirow{2}{*}{\multicolumn{2}{|c|}{ PLANO DE TRABALHO }} & 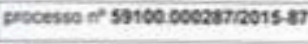 \\
\hline & & & & & Pagera tos \\
\hline \multicolumn{6}{|c|}{ 1. ceocos cacastras } \\
\hline \multicolumn{6}{|l|}{ IT-PROPONENTE } \\
\hline \multicolumn{5}{|c|}{ 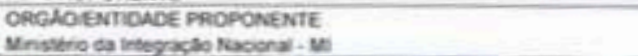 } & $\begin{array}{l}\text { CNPI } \\
\text { cos } 3533580001 \% 6\end{array}$ \\
\hline \multicolumn{6}{|c|}{ 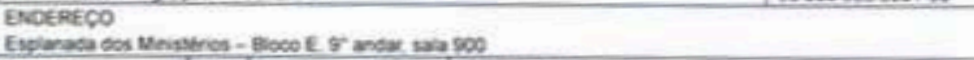 } \\
\hline $\begin{array}{l}\text { Cowoe } \\
\text { Brasian }\end{array}$ & & \multicolumn{2}{|c|}{$\begin{array}{l}\text { CEP } \\
70000020\end{array}$} & \multicolumn{2}{|l|}{ 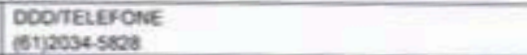 } \\
\hline \multicolumn{6}{|c|}{$\begin{array}{l}\text { UGiGentso Refsassadors } \\
\text { S3001300001 }\end{array}$} \\
\hline \multicolumn{5}{|c|}{$\begin{array}{l}\text { NOUE DO RESPCANSAVEL } \\
\text { Orusioo Gros }\end{array}$} & $\begin{array}{l}\text { CPF } \\
\text { sasese ves is }\end{array}$ \\
\hline \multicolumn{3}{|c|}{ 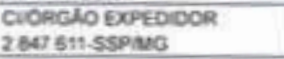 } & \multicolumn{2}{|c|}{$\begin{array}{l}\text { CARCO } \\
\text { Secretare de intombralloge }\end{array}$} & FUNCLO \\
\hline
\end{tabular}

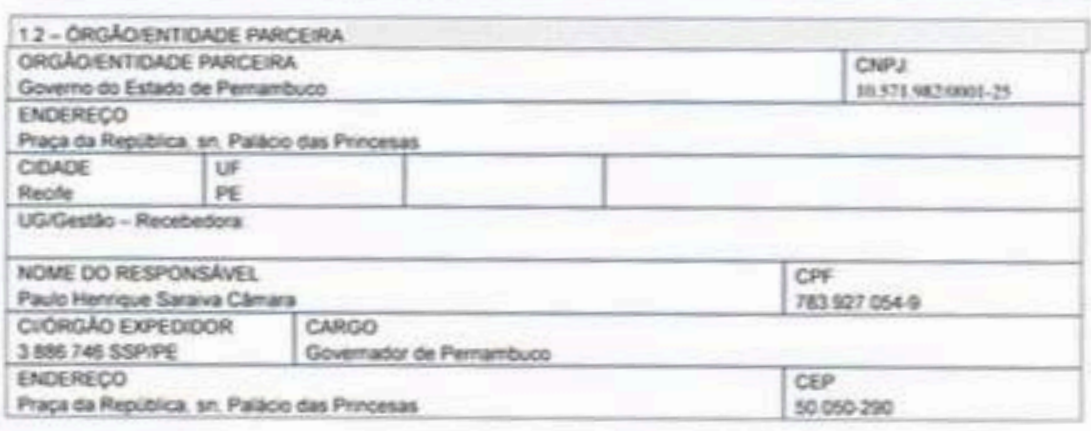

\begin{tabular}{|c|c|c|c|c|}
\hline \multicolumn{4}{|c|}{12 - STIERVERENTE EXECUIOR } & \\
\hline \multicolumn{4}{|c|}{ 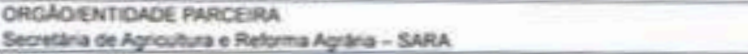 } & $\begin{array}{l}\operatorname{CNe} 2 \\
\text { to sr2 } \operatorname{css} \cos 130\end{array}$ \\
\hline \multicolumn{5}{|c|}{$\begin{array}{l}\text { Evicereco } \\
\text { Autnca Cuanga } 2000 \text { Corsero Rectope }\end{array}$} \\
\hline \multirow{2}{*}{\multicolumn{5}{|c|}{ 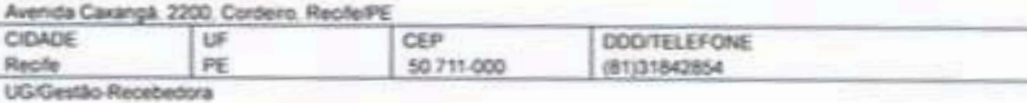 }} \\
\hline & \\
\hline \multicolumn{4}{|c|}{ 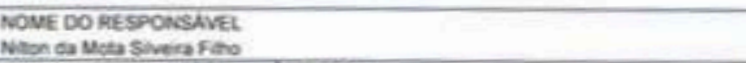 } & CF 40039515400 \\
\hline \multicolumn{2}{|l|}{$\begin{array}{l}\text { COOAGDO EREDIDOR } \\
2196396 \text { SSPPE }\end{array}$} & \multicolumn{2}{|c|}{ 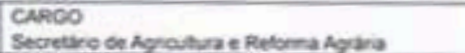 } & FutCDO \\
\hline
\end{tabular}




\begin{tabular}{|c|c|c|}
\hline \multirow{2}{*}{ 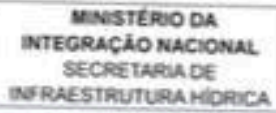 } & \multirow{2}{*}{ PLANO DE TRABALHO } & 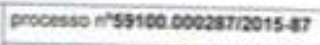 \\
\hline & & Pagra es \\
\hline
\end{tabular}

5. CAONoGrueA DE DESEUBOL SO (RS 1009

VALOR DAS PMRCELAS

Concedente/Proponente - MI

\begin{tabular}{|c|c|c|c|c|c|c|c|c|c|}
\hline Funconal Programbea & $\begin{array}{l}\text { Netanuavezs } \\
\text { a Despess }\end{array}$ & roses & $\underset{N}{2}$ & wes & soves & $\begin{array}{c}5 \\
\text { wes }\end{array}$ & $\underset{\text { vets }}{0}$ & $\underset{m e s}{T}$ & vis \\
\hline Ie S44 2081.59000020 & 4esost & $1000 \cos 60$ & & & seaseng & & & & \\
\hline 185422051 12EP 0000 & 2escos: & $2 x e c 0000$ & & & smisuen & & & & \\
\hline Tota2 & & Inotocesent & & & nowness & & & & \\
\hline
\end{tabular}

\begin{tabular}{|c|c|c|c|c|c|c|c|c|c|}
\hline Funcers Alogramitical & $\begin{array}{l}\text { Wetaniabuesa } \\
\text { da Despesa }\end{array}$ & 9 sets & $10 \mathrm{rats}$ & $i_{\text {ints }}$ & $\begin{array}{l}\text { iz } \\
\text { ves }\end{array}$ & $\begin{array}{l}19 \\
\text { wits }\end{array}$ & wes & $\begin{array}{l}15^{\circ} \\
\text { wets }\end{array}$ & $\begin{array}{l}\text { is: } \\
\text { wists }\end{array}$ \\
\hline $18544205: 58000020$ & 403051 & & $262053=0$ & & & & & & \\
\hline 78544205112890000 & eescst & & ratseshos & & & & & & \\
\hline TOTAC & & & Bastenco & & & & & & \\
\hline
\end{tabular}

\begin{tabular}{|c|c|c|c|c|c|c|c|c|c|}
\hline Funourd Progandica & $\begin{array}{l}\text { Uetankarueza } \\
\text { a Despesa }\end{array}$ & $\begin{array}{c}170 \\
w 4\end{array}$ & terses & $\begin{array}{c}19 \\
\text { wis }\end{array}$ & $\begin{array}{l}20 \\
\text { wes }\end{array}$ & $\begin{array}{l}210 \\
\text { Wes }\end{array}$ & $222^{\circ} \mathrm{wts}$ & $\begin{array}{l}20 \\
\text { vis }\end{array}$ & $\begin{array}{l}24^{\circ} \\
\text { ues }\end{array}$ \\
\hline 185462051.59000020 & & & estraten & & & & $300 \mathrm{enses}$ & & \\
\hline 185442051 12EP 0020 & & & $29 \mathrm{mectas}$ & & & & 100000000 & & \\
\hline TOTA & & & 20nseitss & & & & $2 \operatorname{cosec00} \theta$ & & \\
\hline
\end{tabular}

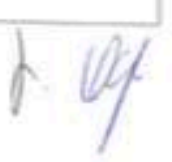

\begin{tabular}{|c|c|c|c|c|}
\hline \multirow{2}{*}{$\begin{array}{l}\text { reograms of Trabuino } \\
\text { (Projeto/Asividade) }\end{array}$} & \multicolumn{2}{|r|}{ Natureza da detpesa } & \multirow[t]{2}{*}{ Fonte } & \multirow{2}{*}{$\begin{array}{l}\text { Tot2L } \\
\text { (RS) }\end{array}$} \\
\hline & Coligo & Especiffensiso & & \\
\hline \multirow{2}{*}{$\begin{array}{l}18.54 .2051 .5580 .0020 \\
18.5 e 4.2051 .12 E P .0020\end{array}$} & 443051 & Ocrase intasclo & 900 & Co one 41700 \\
\hline & 443051 & Oenss en instacto & 100 & $45 \sin 200423$ \\
\hline \multicolumn{4}{|c|}{ Totat Gerat } & 8071222131 \\
\hline
\end{tabular}




\begin{tabular}{|c|c|c|}
\hline \multirow{2}{*}{$\begin{array}{l}\text { MINISTERIO DA } \\
\text { INTEGRACAO NACIONAL } \\
\text { SECRETARAA DE } \\
\text { ANFRAESTRUTURA HIDFICA }\end{array}$} & \multirow[b]{2}{*}{ PLANO DE TRABALHO } & pocesso in $59100.0002872015-87$ \\
\hline & & Pagna 55 \\
\hline
\end{tabular}

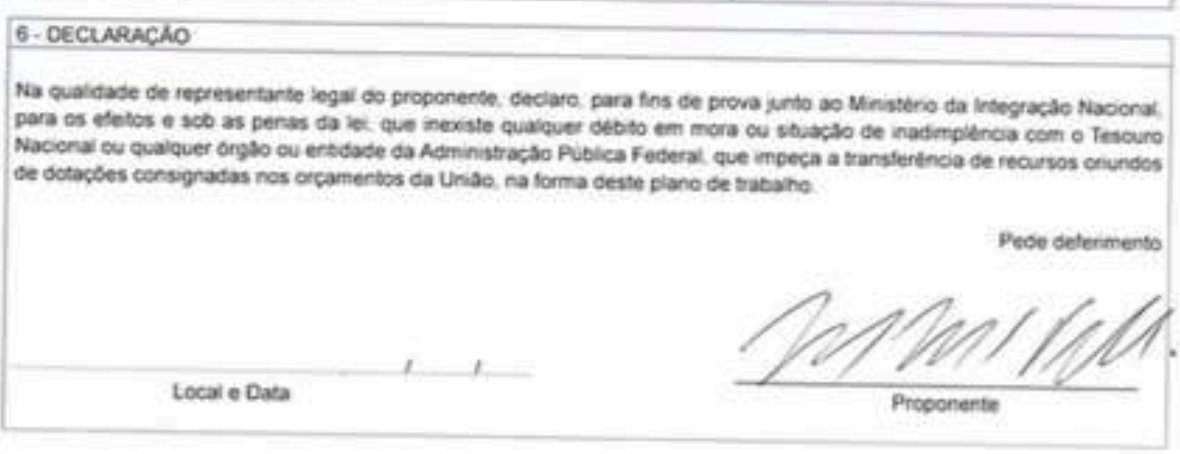

7. APROVACAO PELO CONCEDENTE
Agrovaso
Onkuailic
Local e Data




\begin{tabular}{|c|c|c|c|c|c|c|c|}
\hline \multirow{2}{*}{\multicolumn{2}{|c|}{$\begin{array}{l}\text { MINISTERIO DA } \\
\text { INTEGRACAO NACIONAL } \\
\text { SECRETARIA DE } \\
\text { NFRAESTRUTURA HIDRICA }\end{array}$}} & \multirow{2}{*}{\multicolumn{2}{|c|}{ PLANO DE TRABALHO }} & \multicolumn{4}{|c|}{ processo in $59100.0002872015-87$} \\
\hline & & & & \multicolumn{4}{|l|}{ Pagna as } \\
\hline \multicolumn{8}{|c|}{ 4-CRONOGRAMA DE EXECUCAO } \\
\hline \multirow{2}{*}{ Meta } & \multirow{2}{*}{$\begin{array}{c}\text { Etasa } \\
\text { Fase }\end{array}$} & \multirow[b]{2}{*}{ Espectcacso } & \multirow{2}{*}{ Lecaltracalo } & \multicolumn{2}{|l|}{ Indicador Finice } & \multicolumn{2}{|c|}{ Durasso } \\
\hline & & & & Unidade & Oode & mice & Termino \\
\hline \multirow[t]{3}{*}{1} & & $\begin{array}{l}\text { Implantaça das Estrufturas de } \\
\text { Abastecimento de Agua nas } \\
\text { Comunidades Rurais a Longo dos } \\
\text { Canais do Pisf - Meta ? }\end{array}$ & PE & $\begin{array}{l}\text { Siotema de } \\
\text { Abastecimento }\end{array}$ & 14 & ATC & $\begin{array}{l}\text { ATC+8 } \\
\text { meses }\end{array}$ \\
\hline & 11 & 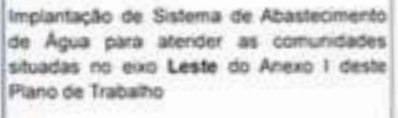 & & $\begin{array}{l}\text { Sistema de } \\
\text { Abastecinento }\end{array}$ & 3 & ATC & $\begin{array}{l}\text { ATc.d } \\
\text { meties }\end{array}$ \\
\hline & 12 & 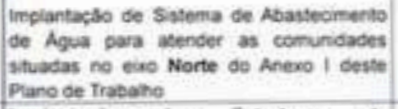 & & $\begin{array}{c}\text { Sistema se } \\
\text { Abastecmento }\end{array}$ & 11 & ATC & $\begin{array}{l}\text { ATC*a } \\
\text { meses }\end{array}$ \\
\hline \multirow[t]{3}{*}{2} & & $\begin{array}{l}\text { Implantacia das Estruturas de } \\
\text { Abastecimento de Agua nas } \\
\text { Comunidades Rurais ao Lengo dos } \\
\text { Canais do PISF-Deta } 2\end{array}$ & PE & $\begin{array}{c}\text { Sistema de } \\
\text { Abastecimento }\end{array}$ & 15 & $\begin{array}{l}\text { ATC+8 } \\
\text { meses }\end{array}$ & $\begin{array}{l}\text { ATC*15 } \\
\text { meses }\end{array}$ \\
\hline & 29 & $\begin{array}{l}\text { Implantacia de Sistems de Abastecimento } \\
\text { De Agua para atender as comunidades } \\
\text { stuadas no soxo Leste do Anexo li deste } \\
\text { Prano de Trabaho }\end{array}$ & & $\begin{array}{l}\text { Sstema de } \\
\text { Abasteomento }\end{array}$ & 5 & $\begin{array}{l}\text { ATC*B } \\
\text { mesest }\end{array}$ & $\begin{array}{l}\text { AtC-16 } \\
\text { meses }\end{array}$ \\
\hline & 22 & 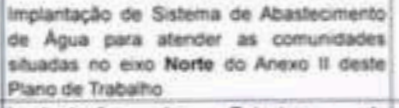 & & & 9 & $\begin{array}{l}\text { AIC*B } \\
\text { meses }\end{array}$ & $\begin{array}{l}\text { ArC. } 16 \\
\text { meses }\end{array}$ \\
\hline \multirow[t]{3}{*}{3} & & $\begin{array}{l}\text { Implantaça das Estruturas de } \\
\text { Abastecimiento de Agua nas } \\
\text { Comunidades Rurais ao Longo dos } \\
\text { Canais do PISF-Meta } 3\end{array}$ & PE & $\begin{array}{c}\text { Sistema de } \\
\text { Abastecimento }\end{array}$ & 13 & $\begin{array}{l}\text { AIC+16 } \\
\text { meses }\end{array}$ & $\begin{array}{l}\text { ATC*24 } \\
\text { imeses }\end{array}$ \\
\hline & 3: & 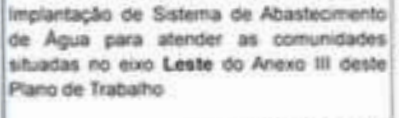 & & $\begin{array}{c}\text { Sateres do } \\
\text { Abastecimentos }\end{array}$ & 10 & $\begin{array}{l}\text { ATC: } 16 \\
\text { meses }\end{array}$ & $\begin{array}{l}\text { ArC } \cdot 24 \\
\text { meses }\end{array}$ \\
\hline & & 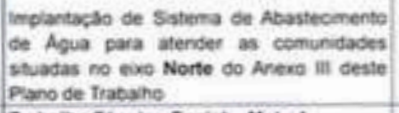 & & $\begin{array}{l}\text { Suterna de } \\
\text { Abastecimento }\end{array}$ & 3 & $\begin{array}{l}\text { ATC. } 16 \\
\text { meses }\end{array}$ & $\begin{array}{l}\text { Arct } 24 \\
\text { meses }\end{array}$ \\
\hline 4 & 41 & 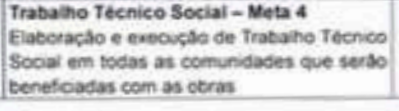 & PE & $\begin{array}{l}\text { Relatónio de } \\
\text { Acompanhamento } \\
\text { per Sistema do } \\
\text { Abastecimento }\end{array}$ & $\$ 2$ & ATC & $\begin{array}{l}\text { ATC } 224 \\
\text { meses }\end{array}$ \\
\hline \multicolumn{8}{|c|}{ Nota: $A T C=$ Data de Rssinaturs do Temno de Compromisso } \\
\hline
\end{tabular}




\begin{tabular}{|c|c|c|c|c|c|c|c|}
\hline \multirow{2}{*}{ Municiplo } & \multirow{2}{*}{ Estado } & \multirow{2}{*}{ Comunidades } & \multirow{2}{*}{$\begin{array}{l}\text { Populacto } \\
\text { 2013 (nab) }\end{array}$} & \multicolumn{2}{|c|}{ Coondenadas } & \multirow{2}{*}{ Siatema } & \multirow{2}{*}{$\begin{array}{l}\text { Canto } \\
\text { Estrmade } \\
\text { (as) }\end{array}$} \\
\hline & & & & $N(m)$ & $E(m)$ & & \\
\hline Foresta & $P E$ & Bara do Cormege & \multirow[b]{2}{*}{216} & 2634754 & 275474 & \multirow[b]{2}{*}{ Angess } & \multirow[b]{2}{*}{$2134 \cos 28$} \\
\hline Forest & PE & 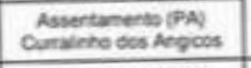 & & $2034 \times 54$ & 57647 & & \\
\hline Foresta & $P E$ & $\begin{array}{c}\text { Assertamerto ipA } \\
\text { Layeso }\end{array}$ & \multirow[b]{2}{*}{60} & 9043371 & 40068 & \multirow{2}{*}{ Forgetapeso } & \multirow{2}{*}{230557207} \\
\hline Floresta & PE & 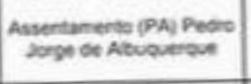 & & 9044823 & Set org & & \\
\hline Forests & $\underline{\phi \varepsilon}$ & Lagonite & \multirow{2}{*}{$\pi$} & 9095568 & Sos 341 & \multirow{2}{*}{ Rlopa Veles } & \multirow{2}{*}{$1: \operatorname{ses} 240<5$} \\
\hline Forecta & $P E$ & Moga Veha & & 2000309 & 587291 & & \\
\hline Cabences & $P E$ & 2060 & \multirow{5}{*}{ sess } & 5002038 & 454392 & \multirow{5}{*}{ seba } & \multirow{5}{*}{6001222.56} \\
\hline Cabroso & PE & Uanfe & & 2004024 & 49719 & & \\
\hline Cabneces & $\rho E$ & veresa & & \begin{tabular}{|l|l|}
0050456 \\
\end{tabular} & $45 \mathrm{Nan}$ & & \\
\hline Catrodos & FE & $\begin{array}{l}\text { Assentopests (PA) } \\
\text { Twast }\end{array}$ & & 9061765 & tese 13? & & \\
\hline Csencoso & $P E$ & $540 \times 006$ & & 9054177 & 200312 & & \\
\hline Casocob & $P E$ & Conera das Peom & \multirow{4}{*}{ sets } & 90ress: & 482900 & \multirow{4}{*}{ Curalinto } & \multirow{4}{*}{$2 \pi 73=570$} \\
\hline Cacentes & $P E$ & Usidacin & & 9072458 & 25096 & & \\
\hline Cacrocos & $P E$ & Cunglitio & & 9000220 & 202412 & & \\
\hline Cxencos & PE & Banuren & & 9077685 & 056254 & & \\
\hline Cabreder & $P E$ & Toco fints & \multirow{2}{*}{316} & 9056566 & 205205 & \multirow{2}{*}{ Coengurna } & \multirow[t]{2}{*}{23069242} \\
\hline Cateros & PE & Cxecsurta & & 9054906 & 406063 & & \\
\hline Conecos & $F E$ & Portalatha & 304 & 4 seg 178 & 9057814 & Porta a ina & 199030462 \\
\hline ciences & pe & $\begin{array}{c}\text { Assentanerso (PA) } \\
\text { dovertude }\end{array}$ & \multirow{2}{*}{212} & 9058441 & 403008 & \multirow{2}{*}{ duresube } & \multirow{2}{*}{$2.56+176 \pi$} \\
\hline Cuerces & $P \varepsilon$ & 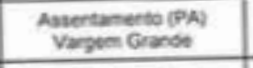 & & 9058421 & 40008 & & \\
\hline Panoremen & PE & \begin{tabular}{|c|} 
Avsertamento PNN NOE \\
Movers \\
\end{tabular} & 120 & 9092.48 & $\cos 683$ & Abel Movers & r cos nes es \\
\hline Verofearse & PE & $\begin{array}{c}\text { Astertanegba pay Nessa } \\
\text { Sra Agareces il }\end{array}$ & $\ln$ & 9.100634 & 506887 & $\begin{array}{l}\text { Nowsasa } \\
\text { Nevecaea in }\end{array}$ & 5631044 \\
\hline Paramen & $P E$ & $\begin{array}{c}\text { Asturtarnerto (PA) Nove } \\
\text { Via } \\
\end{array}$ & 50 & 9000865 & $408<10$ & Nous Via & toss 1979 \\
\hline Pamamern & $P E$ & $\begin{array}{l}\text { Assertamento (PA) } \\
\text { Varerano Das Siva }\end{array}$ & 276 & 9065923 & 62262 & $\begin{array}{l}\text { Voretyon } \\
\text { Das Siva }\end{array}$ & 1531 ces os \\
\hline Catrotod & PE & $\begin{array}{l}\text { Oulombola de Cour ses } \\
\text { Raches }\end{array}$ & 104 & $9055 \times 29$ & 40397 & 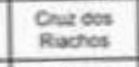 & 3082821 \\
\hline Crences & $\mathrm{PE}$ & $\begin{array}{l}\text { Oilombolis be } \\
\text { Fazereas Sortina }\end{array}$ & 112 & 9083670 & 407018 & $\begin{array}{l}\text { Favenda } \\
\text { Sortana }\end{array}$ & sescater \\
\hline
\end{tabular}


ANEXOII

\begin{tabular}{|c|c|c|c|c|c|c|c|}
\hline \multirow{2}{*}{ Munielpio } & \multirow{2}{*}{ Estado } & \multirow{2}{*}{ Comunidades } & \multirow{2}{*}{$\begin{array}{l}\text { Populaças } \\
2013 \text { (hab) }\end{array}$} & \multicolumn{2}{|c|}{ Coordenudas } & \multirow{2}{*}{ Siatema } & \multirow{2}{*}{$\begin{array}{l}\text { Custo } \\
\text { Estimado } \\
\text { [RS) }\end{array}$} \\
\hline & & & & $N(m)$ & $E(m)$ & & \\
\hline Flonenta & $P E$ & Trombeta & \multirow{4}{*}{176} & 9060652 & 595247 & \multirow{4}{*}{ Caraiba } & \multirow{4}{*}{263847578} \\
\hline Floresta & PE & Legou Rasa & & 9042042 & 59204 & & \\
\hline Ficeesta & $P E$ & Jabury & & 3008852 & 594376 & & \\
\hline Feresta & PE & Caraibu & & 9002.136 & 5004000 & & \\
\hline Ficresta & $P E$ & Forseca & \multirow{6}{*}{$\$ 36$} & 9050032 & 609709 & \multirow{6}{*}{$\begin{array}{c}\text { Tinbulero } \\
\text { dos } \\
\text { Perost }\end{array}$} & \multirow{6}{*}{324809231} \\
\hline Floresta & $P E$ & Campo Alegre & & 904964 & 605.801 & & \\
\hline Florests & PE & $\begin{array}{l}\text { Assentamento (PA) Caideribo do } \\
\text { Periguto }\end{array}$ & & 5054614 & 619210 & & \\
\hline Fienesta & $P E$ & Asseritamento (PA) Picocas & & 9054614 & 6192210 & & \\
\hline Feresta & PE & Assentanento (PA) Serra Kegra & & 9054257 & $\cos 939$ & & \\
\hline Ficresta & PE & Tabulerie do Porces & & 9054256 & 605.051 & & \\
\hline Fioresta & PE & Lacand & \multirow{4}{*}{100} & 90645 to & 62058 & \multirow{4}{*}{ Jacart } & \multirow{4}{*}{191367270} \\
\hline Foreves & $P E$ & Ponteras & & 9064492 & $5+8237$ & & \\
\hline Fiorests & $P E$ & S40 Siventite & & 9064478 & 617306 & & \\
\hline Fioresta & $P E$ & Assentamerts (P/) Jacare & & 9063200 & 621569 & & \\
\hline Eetseng & $P E$ & Seira Eranca & \multirow{6}{*}{500} & 201620 & 620564 & \multirow{6}{*}{$\begin{array}{l}\text { Sena } \\
\text { Branca }\end{array}$} & \multirow{6}{*}{3.75614004} \\
\hline Betsia & $P E$ & Lagea do Serrobe & & 9074597 & 629722 & & \\
\hline Betana & $P E$ & Volts & & 9073124 & 622656 & & \\
\hline Betäna & PE & Cachoena & & 9080286 & 6263332 & & \\
\hline Betang & PE & Cacmbinta & & 906869 & 398160 & & \\
\hline Cositosa & PE & Pou Fento & & 9076469 & 625656 & & \\
\hline Custosa & $P E$ & Placho so Mef & 80 & 9075.623 & 628440 & $\begin{array}{c}\text { Fiacho do } \\
\text { Net }\end{array}$ & $+438875,06$ \\
\hline Custosa & PE & Bawa & 64 & 9004404 & $632: 165$ & Baxa & $2+3805246$ \\
\hline Catencos & PE & $\begin{array}{l}\text { Assentamento (PA) Antonio of } \\
\text { Baros }\end{array}$ & \multirow{3}{*}{100} & 9086201 & 468.184 & \multirow{3}{*}{$\begin{array}{l}\text { Antoning } \\
\text { oe Bantas }\end{array}$} & \multirow{3}{*}{192023993} \\
\hline Catrobo & $P E$ & Represa & & 9088507 & $\$ 62.931$ & & \\
\hline Cabrobo & $P E$ & Sanhare & & 9003.147 & $\$ 62044$ & & \\
\hline Salperio & $P E$ & Pau Prete & \multirow{5}{*}{804} & 9094703 & कos? Cs5 & \multirow{5}{*}{$\begin{array}{l}\text { Sitios } \\
\text { Noves }\end{array}$} & \multirow{5}{*}{5.12685729} \\
\hline Salquero & $P E$ & Varzea Recends & & 2004740 & 458255 & & \\
\hline Salgueiro & $P E$ & Angeo & & 905430 & 469339 & & \\
\hline Savqueto & $P E$ & Sises Moves & & 9003916 & 471573 & & \\
\hline Salquete & $P E$ & Livamento & & 9004095 & 472000 & & \\
\hline Terra Nova & PE & Oulombola de Contendas & 204 & $9+02009$ & 470.159 & Contends & 246598540 \\
\hline Mrandba & $P E$ & Ouliombola de Senta do Tahado & 96 & 9091.497 & 534482 & $\begin{array}{l}\text { Sems do } \\
\text { Tahado }\end{array}$ & 1.841 se2 st \\
\hline Mrandba & $P E$ & Qulombola be duacerio Grande & 175 & $\cos 651$ & 528.358 & $\begin{array}{l}\text { Juasero } \\
\text { Grande }\end{array}$ & ars ast, 73 \\
\hline Mranoba & PE & Oulombola de Avaca & 72 & 9.091 .104 & 537606 & Araces & 53153451 \\
\hline Minandea & PE & Quilonbola de fejsolpesse & 200 & 9090274 & 528938 & $\begin{array}{l}\text { Fejol } \\
\text { Posse }\end{array}$ & 1.10849177 \\
\hline Nrandea & PE & Qulcenecia de Quemadas & 76 & 9101043 & 526714 & Quemada & 800510.78 \\
\hline Mrandiba & $P E$ & Quilembels of Pedra Branca & 96 & 9009.200 & 543769 & $\begin{array}{l}\text { Peora } \\
\text { Eranca }\end{array}$ & Bt4 737,12 \\
\hline
\end{tabular}


Anexo 3 - Plano de Trabalho original para implantação de infraestrutura de abastecimento de água para comunidades rurais ao longe do PISF assinado entre MI e SARA

\begin{tabular}{|c|c|c|c|c|c|c|c|}
\hline \multirow[b]{2}{*}{ Noniciple } & \multirow{2}{*}{ Catado } & \multirow{2}{*}{ Consuldaber } & \multirow{2}{*}{ popriacks } & \multicolumn{2}{|c|}{ Cosionnudes } & \multirow{2}{*}{ Satoms } & \multirow{2}{*}{ Eatimaso } \\
\hline & & & & $\mathbf{w}(\mathbf{m})$ & tint & & \\
\hline Conses & $\mathrm{FE}$ & Seninto & \multirow{3}{*}{ sea } & $1000 \times 5$ & ses 44 & \multirow{3}{*}{ pupenclem } & \multirow{3}{*}{ 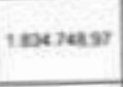 } \\
\hline Conles:s & $F$ & Poss be Case & & severass & 0420 & & \\
\hline Coubes & FE & Voutova & & tose sot & suesa & & \\
\hline Cualbes & $\boldsymbol{n}$ & Caceveta Borena: & \multirow{3}{*}{$\cos$} & 3057201 & 00225 & \multirow{3}{*}{ Earo Virmethe } & \multirow{3}{*}{2019222625} \\
\hline $\begin{array}{l}\text { Cutbers: } \\
\text { Serona }\end{array}$ & $\boldsymbol{p e}$ & watenaders & & $5 \operatorname{cosessa}$ & ecasses & & \\
\hline Sethe & $\bar{E}$ & Henevererthe & & Snot 86 & 65192 & & \\
\hline senters & pe & Faok & \multirow{4}{*}{$\mathrm{ses}$} & 3005622 & $\cos 50^{\circ}$ & \multirow{4}{*}{ fanda } & \multirow{4}{*}{ 261062:.8 } \\
\hline Sertes & $F E$ & Anes & & 2502474 & stres & & \\
\hline Sectons & $\tilde{n}$ & Won & & 309762 & 60539 & & \\
\hline Solons & $F E$ & Fone & & sosages & 605 & & \\
\hline setans & FE & Deventho & \multirow{4}{*}{$m$} & 1892314 & $06 m$ & \multirow{4}{*}{ Naven } & \multirow{4}{*}{3200220050} \\
\hline Serises & FE & Anews & & $3056 \operatorname{ses}$ & Exas & & \\
\hline Sectura & $\boldsymbol{n}$ & Bose & & $2 \operatorname{sen} 513$ & $\sin 20$ & & \\
\hline Seting & $\boldsymbol{r}$ & Woen & & 2.0050 & 60020 & & \\
\hline Secha & PE & Acued linin & \multirow{5}{*}{906} & $3+0600$ & $\cos \sin$ & \multirow{5}{*}{ Mabuerts } & \multirow{5}{*}{ ansese as } \\
\hline Sertan & $\bar{c}$ & Panten & & 3108.60 & seaser & & \\
\hline Senta & FE & Losa Sigeats & & $21062 \mathrm{n}$ & $\cos 60$ & & \\
\hline $\begin{array}{l}\text { Ouobsed } \\
\text { Sertina }\end{array}$ & $\boldsymbol{v e}$ & Stohasens & & 290522 & 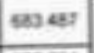 & & \\
\hline Feane & FE & Lerda onge & & 2 tos ase & ass 21 & & \\
\hline Senen & A & Fasmoa Sarbinga & & 211247 & 60460 & & \\
\hline Sentho & $F E$ & Phache Oannoses & & $2 \pi n$ Sses & $\operatorname{cosen}$ & & \\
\hline Sectine & $\pi$ & Ruche de Vlet & & 3 somasn & $5 \sin 300$ & & \\
\hline Senthe & FE & Eanobinas & & $3 n+610$ & Cos 44: & & \\
\hline senves & $n$ & $\operatorname{xec}$ & 200 & 300072 & $602 \mathrm{abi}$ & teser & andestive \\
\hline Sectane & $\bar{r}$ & Coonsadanas & & 310078 & $\cos (\sin$ & & \\
\hline Sedne & $\bar{E}$ & Fundes & & $21075 a$ & 60.596 & & \\
\hline Serdins & AE & Sas Onemate bo bans & & $3+1200$ & enaxs & & \\
\hline sented & n & Coventerhs & & 3108002 & eas os & & \\
\hline Senonse & es & inceder & & $3 \pi 18345$ & 65231 & & \\
\hline Seten & $P \varepsilon$ & Ste fanciace & $x$ & sira $\mathrm{xa}$ & 605213 & Cot & $2.320 \mathrm{ses} \pi$ \\
\hline Selana & $\overline{\boldsymbol{\alpha}}$ & Cot & & $9 \sin 79$ & esross & & \\
\hline Cunsose & 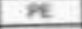 & Saratuses & $m$ & $2 \cos 22 \pi$ & $652 \pi 55$ & aroneba & $125 s \in c s$ \\
\hline Sendins & $\boldsymbol{\kappa}$ & Nenambvourte & 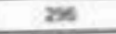 & 3126211 & coseses & Fuinambugunte & 100450227 \\
\hline Senta & $\tilde{n}$ & Pringere ee Fear & $\mathrm{z}$ & 515208 & Gait 122 & 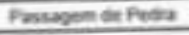 & 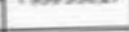 \\
\hline Susper & $P E$ & Babe whery & & 3142510 & arest & & \\
\hline serenen & $\boldsymbol{\varepsilon}$ & 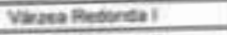 & & $2 \operatorname{seg} 306$ & 2006r? & & \\
\hline suleos & $n$ & 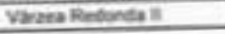 & & 3162.54 & 4530 & & \\
\hline soper & $n$ & 0 & coset & 5 sot.sse & anzas & venoperses & 2 ont seces \\
\hline Sucpen & FE & Daniegreves & & Fes so & $\cos 27$ & & \\
\hline Sirven & FE & Neobrana & & 210420 & 0255 & & \\
\hline sonen & 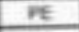 & Mana & & 510417 & 40374 & & \\
\hline sone & $\underline{\underline{E}}$ & uscoses & & 2010129 & 400005 & & \\
\hline Sones & $\bar{E}$ & Unaran & 304 & 010022 & 0905 & $u$ & 2200109 \\
\hline senes & $n$ & vene & & $3 \sin 27$ & 0.65 & & \\
\hline cosite & $\boldsymbol{N E}$ & 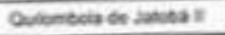 & 520 & $10 \cos 403$ & esesso & Janed : & 2376200 \\
\hline
\end{tabular}


Anexo 3 - Plano de Trabalho original para implantação de infraestrutura de abastecimento de água para comunidades rurais ao longo do PISF assinado entre MI e Secretaria de Estado de Infraestrutura, dos Recursos Hídricos, do Meio Ambiente e da Ciência e Tecnologia do Estado da Paraíba

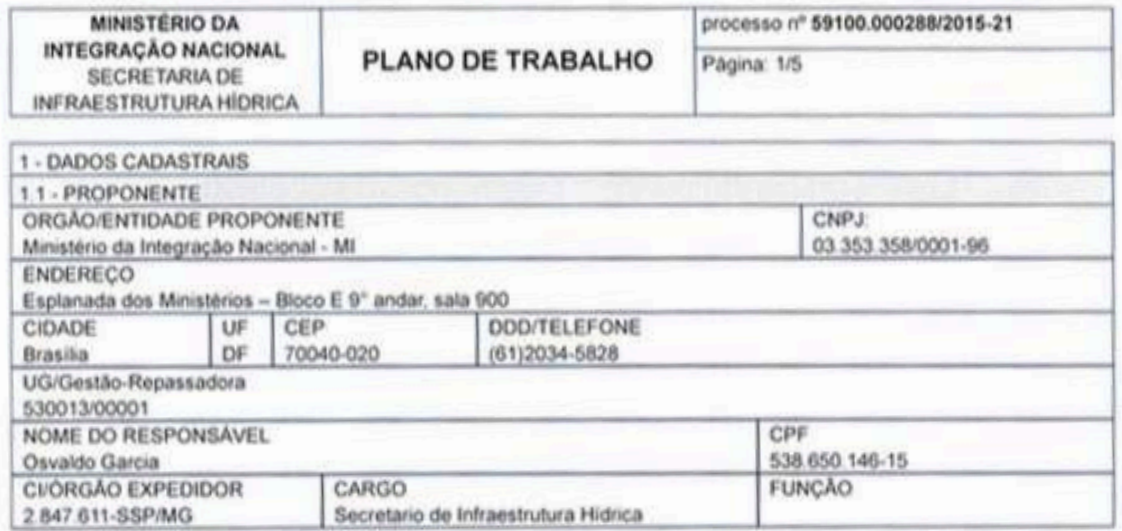

\begin{tabular}{|c|c|c|c|c|c|}
\hline \multicolumn{6}{|c|}{12 - ORGAOIENTIDADE PARCEIRA } \\
\hline \multicolumn{5}{|c|}{$\begin{array}{l}\text { ORGAOIENTIDADE PARCEIRA } \\
\text { Governo do Estado da Paraiba }\end{array}$} & $\begin{array}{l}\text { CNPJ } \\
087611240001-00\end{array}$ \\
\hline \multicolumn{6}{|c|}{$\begin{array}{l}\text { ENDERECO } \\
\text { Avenida Dugue de Caxias. Centro, Palacio da Redencto }\end{array}$} \\
\hline $\begin{array}{l}\text { CIDADE } \\
\text { Jodo Pessoa }\end{array}$ & \multicolumn{2}{|c|}{$\begin{array}{l}\text { UF } \\
P B\end{array}$} & $\begin{array}{l}C E P \\
5 B 013-140\end{array}$ & \multicolumn{2}{|l|}{$\begin{array}{l}\text { ODOTELEFONE } \\
\text { (83) } 3216 \cdot 8000\end{array}$} \\
\hline \multicolumn{6}{|c|}{ UG/Gestao-Recebedora } \\
\hline \multicolumn{5}{|c|}{$\begin{array}{l}\text { NOME DO RESPONSAVEL. } \\
\text { Ricardo Vieira Coutinho }\end{array}$} & $\begin{array}{l}\text { CPF } \\
218713534.91\end{array}$ \\
\hline \multicolumn{2}{|c|}{$\begin{array}{l}\text { CUORGAO EXPEOIDOR } \\
516.331 \text { SSPPB }\end{array}$} & \multicolumn{2}{|c|}{$\begin{array}{l}\text { CARGO } \\
\text { Governodor do Estado }\end{array}$} & & $\begin{array}{l}\text { FUNCAO } \\
\text { Governador }\end{array}$ \\
\hline \multicolumn{4}{|c|}{$\begin{array}{l}\text { ENDERECO } \\
\text { Avenida Duque de Cavias. }\end{array}$} & & $\begin{array}{l}\text { CEP } \\
\text { SS013-140 }\end{array}$ \\
\hline
\end{tabular}

\begin{tabular}{|c|c|c|c|c|c|c|}
\hline \multicolumn{7}{|c|}{ 13-ORGAO/ENTIOADE INTERVENIENTE } \\
\hline \multicolumn{6}{|c|}{ OROAOVENTIOAOE PARCEIRA } & CNPS \\
\hline \multicolumn{6}{|c|}{$\begin{array}{l}\text { Secretaria do Estado da infraestrutura. dos Recursos Hidicos. do Meio Ambiente e da Ciencia } \\
\text { - Tecnotogia do Estado da Paraiba }\end{array}$} & $02.221 .96210001-04$ \\
\hline \multicolumn{7}{|c|}{$\begin{array}{l}\text { ENDERECCO } \\
\text { Av Mnisto Jose Americo de Ameida sn. terieo DER. Torre }\end{array}$} \\
\hline $\begin{array}{l}\text { CIDAOE } \\
\text { Jodo Pessoa }\end{array}$ & \multicolumn{2}{|c|}{$\begin{array}{l}\text { UF } \\
\text { PB }\end{array}$} & $\begin{array}{l}\text { CEP } \\
58.040-300\end{array}$ & \multicolumn{3}{|l|}{$\begin{array}{l}\text { DOD/TELEFONE } \\
\text { (83) } 3218-4371\end{array}$} \\
\hline \multicolumn{7}{|c|}{$\begin{array}{l}\text { UG/Gesiso-Recebedora } \\
\text { 31001 }\end{array}$} \\
\hline \multicolumn{5}{|c|}{$\begin{array}{l}\text { NOME OO RESPONSAVEL } \\
\text { Jobo Azevedo Lins FAho }\end{array}$} & \multicolumn{2}{|c|}{$\begin{array}{l}\text { CPF } \\
007091304-20\end{array}$} \\
\hline \multicolumn{2}{|c|}{$\begin{array}{l}\text { CVORGMO EXPEDIDOR } \\
193707 \text { SSPIPB }\end{array}$} & \multicolumn{3}{|c|}{$\begin{array}{l}\text { CARGO } \\
\text { Secretario de Estado dos Recursos Hidricos. do Meio } \\
\text { Ambiente e da Ciencia e Tecnologia }\end{array}$} & \multicolumn{2}{|c|}{$\begin{array}{l}\text { FUNCAO } \\
\text { Sectetario de Estado }\end{array}$} \\
\hline \multicolumn{5}{|c|}{$\begin{array}{l}\text { ENDERECCO } \\
\text { Av Ministro Jose Amenico de Aimeida s'n. törreo. DER. Torre }\end{array}$} & \multicolumn{2}{|c|}{$\begin{array}{l}\text { CEP } \\
58040-300\end{array}$} \\
\hline
\end{tabular}




\begin{tabular}{|c|l|l|}
\hline $\begin{array}{c}\text { MINISTERIO DA } \\
\text { INTEGRAÇÃO NACIONAL } \\
\text { SECRETARIA DE } \\
\text { INFRAESTRUTURA HIDRICA }\end{array}$ & PLANO DE TRABALHO & processo $n^{\circ} 59100.000288 / 2015-21$ \\
\cline { 2 - 3 } & & Pagina 215 \\
\hline
\end{tabular}

\begin{tabular}{|c|c|c|}
\hline \multicolumn{3}{|l|}{ 2. DESCRIÇAO DO PROJETO } \\
\hline Titulo do Projeto & \multicolumn{2}{|c|}{ Periodo de Execuçà } \\
\hline 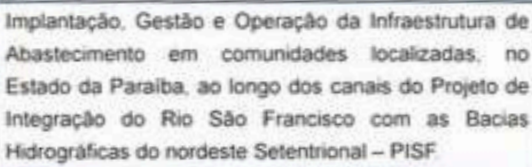 & $\begin{array}{l}\text { Inicio } \\
\text { JANEIRO/2016 }\end{array}$ & $\begin{array}{l}\text { Término } \\
24 \text { (vinte e quatro) meses } \\
\text { apos a ATC }\end{array}$ \\
\hline
\end{tabular}
Identificaçào do Objeto

Implantaçâo, operaçào e geståo dos sistemas de abastecimento de água nas comunidades rurais situadas ao longo dos canais do PISF visando atender a condicionante 21 da Licença de instalaça $n^{\circ}$ 925/2013 especificamente aos itens 15 (Programa de Implantaçăo de Intraestrutura de Abastecimento de Agua ao Longo dos Canais) e 17 (Programa de Desenvolvimento de Comunidades Quilombolas) e 18 (Programa de Apoip e Fortalecimento dos Projetos de Assentamento Existentes ao Longo do Canal) do Projeto Basico Ambientai - PBA, contorme descrito nos itens do PBA e apresentado nos projetos executivos fornecidos pelo MI.

\section{Justificativa da Proposiçăo}

Durante o processo de concessăo da licença para o Projeto de Integraça da Bacia do Rio Sáo Francisco com as Bacias Hidrográficas do Nordeste Setentrional foram avaliados e propostos diversos programas. O Parecer Técnico 15 do IBAMA (No. 15/2007 - COHIDICGENEIDILICIBAAAA) estabelece em seu Alem 2.12

Apresentar, no Programa de Implantaça de Infraestrutura de Abastecimento de Agua as Populaçces ao Longo dos Canars, proposta para viabilzar o tratamento do tods agua fornocida coletivanente, compativel ao atendimento dos padroes de potabilidade estabelecidos pela Portana MS n. 2914/2011

Sendo o emproendedor responsłivel pels implantaçâ: estruturas de captaço prioritariamente junto aos reservatónios. constituidas de tomada d'agua. unidade de bombeamento e estaça compacta de tratamento de áqua Rede de distribuiçà desde as captaçes ate as localidades rurais a serem atendidas. Unidades locais de abastecimento comunitatio (consttuida de caixa d água e chafaria) nas localidades nâo servidas por redes de distribuiça dornicilar (stuaçâ da grande maioria das localidades cadastradas); Poços acoplados a unidades locais de abastecinento comunitario para as comunidades que, dada a sua localizaçào e dimensá, näo se mostre viàvel a aduça da agua dos reservatorios do sistema, desde que haja disponibildade hidrica subterratnea para ta: Cisternas de placas para atender as populaçes isoladas

\begin{tabular}{|c|c|c|c|c|}
\hline \multicolumn{5}{|c|}{ 3. PLANO DE APLICACAO (RS 1,00) } \\
\hline \multirow{2}{*}{$\begin{array}{l}\text { Programa de Trabalho } \\
\text { (ProjetolAtividade) }\end{array}$} & \multicolumn{2}{|r|}{ Natureza da despesa } & \multirow[t]{2}{*}{ Fonte } & \multirow{2}{*}{$\begin{array}{c}\text { TOTAL } \\
\text { (RS) }\end{array}$} \\
\hline & Código & Especificaçào & & \\
\hline \multirow[t]{2}{*}{18.544 .2051 .5900 .0020} & 44.30 .51 & Obras e instalaçðo & 100 & 12.156 .571 .29 \\
\hline & 4430.51 & Obras e Instalaça & 100 & $23.563 .065,06$ \\
\hline \multicolumn{4}{|c|}{ Total Geral } & $35,719636,35$ \\
\hline
\end{tabular}




\begin{tabular}{|c|l|l|}
\hline MINISTÉRIO DA & processo n59100.000288/2015-21 \\
\cline { 3 - 3 } $\begin{array}{c}\text { INTEGRACAOAONACIONAL } \\
\text { SECRETARIA DE } \\
\text { INFRAESTRUTURA HIDRICA }\end{array}$ & PLANO DE TRABALHO & Página 3/5 \\
\hline
\end{tabular}

\begin{tabular}{|c|c|c|c|c|c|c|c|}
\hline \multicolumn{8}{|c|}{ 4. CRONOGRAMADE EXECUCÃO } \\
\hline \multirow{2}{*}{ Meta } & \multirow{2}{*}{$\begin{array}{c}\text { Etapa/ } \\
\text { Fase }\end{array}$} & \multirow{2}{*}{ Especificaçâo } & \multirow{2}{*}{ Localizaçào } & \multicolumn{2}{|c|}{ Indicador Fisico } & \multicolumn{2}{|c|}{ Duraçao } \\
\hline & & & & Unidade & Qde & Inicio & Término \\
\hline \multirow[t]{3}{*}{1} & & 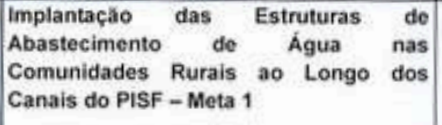 & \multirow[t]{3}{*}{ PB } & $\begin{array}{c}\text { Sistema de } \\
\text { Abastecimento }\end{array}$ & 5 & ATC & $\begin{array}{l}\text { ATC }+8 \\
\text { meses }\end{array}$ \\
\hline & 1.1 & $\begin{array}{l}\text { implantaçao de Sistema de Abastecimento } \\
\text { de Agua para atender as comunidades } \\
\text { situadas no eixo Leste do Anexo I deste } \\
\text { Plano de Trabalho }\end{array}$ & & $\begin{array}{c}\text { Sistema de } \\
\text { Abastecimento }\end{array}$ & 2 & ATC & $\begin{array}{l}\text { ATC+8 } \\
\text { meses }\end{array}$ \\
\hline & 1.2 & $\begin{array}{l}\text { Implantaçâo de Sistema de Abastecimento } \\
\text { de Agua para atender as comunidades } \\
\text { situadas no eoco Norto do Anexo } 1 \text { deste } \\
\text { Plano de Trabalho }\end{array}$ & & $\begin{array}{c}\text { Sistema de } \\
\text { Abastecimento }\end{array}$ & 3 & ATC & $\begin{array}{l}\text { ATC }+8 \\
\text { meses }\end{array}$ \\
\hline \multirow[t]{3}{*}{2} & & 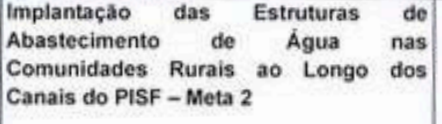 & \multirow[t]{3}{*}{ PB } & $\begin{array}{c}\text { Sistema de } \\
\text { Abastecimento }\end{array}$ & 3 & $\begin{array}{l}\text { ATC+8 } \\
\text { meses }\end{array}$ & $\begin{array}{c}\text { ATC }+16 \\
\text { moses }\end{array}$ \\
\hline & 2.1 & $\begin{array}{l}\text { Implantação de Sisterna de Abastecimento } \\
\text { de Agua para atender as comunidades } \\
\text { situadas no eixo Lesto do Anexo II deste } \\
\text { Plano de Trabalho }\end{array}$ & & $\begin{array}{c}\text { Sistema de } \\
\text { Abastecimento }\end{array}$ & 2 & $\begin{array}{l}\text { ATC }+8 \\
\text { meses }\end{array}$ & $\begin{array}{c}\text { ATC }+16 \\
\text { meses }\end{array}$ \\
\hline & 22 & $\begin{array}{l}\text { Implantaçào de Sistema de Abastecimento } \\
\text { de Agua para atender as comunidades } \\
\text { situadas no eixo Norte do Anexo II deste } \\
\text { Plano de Trabalho }\end{array}$ & & & 1 & $\begin{array}{l}\text { ATC } 88 \\
\text { meses }\end{array}$ & $\begin{array}{c}\text { ATC }+16 \\
\text { meses }\end{array}$ \\
\hline \multirow[t]{3}{*}{3} & \multirow{3}{*}{31} & 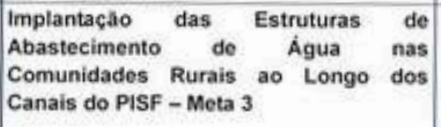 & \multirow[t]{3}{*}{ PB } & $\begin{array}{c}\text { Sistema de } \\
\text { Abastecimento }\end{array}$ & 3 & $\begin{array}{l}\text { ATC+16 } \\
\text { meses }\end{array}$ & $\begin{array}{l}\text { ATC }+24 \\
\text { meses }\end{array}$ \\
\hline & & $\begin{array}{l}\text { Implantaçáo de Sistema de Abastecimento } \\
\text { de Água para atender as comunidades } \\
\text { situadas no eixo Lesto do Anexo III deste } \\
\text { Plano de Trabalho }\end{array}$ & & $\begin{array}{c}\text { Sistema de } \\
\text { Abastecimento }\end{array}$ & 1 & $\begin{array}{l}\text { ATC }+16 \\
\text { meses }\end{array}$ & $\begin{array}{c}\mathrm{ATC}+24 \\
\text { meses }\end{array}$ \\
\hline & & $\begin{array}{l}\text { Implantaçằ de Sistema de Abastecimento } \\
\text { de Agua para atender as comunidades } \\
\text { situadas no eixo Norte do Anexo III deste } \\
\text { Plano de Trabalho }\end{array}$ & & $\begin{array}{c}\text { Sistema de } \\
\text { Abastecimento }\end{array}$ & 2 & $\begin{array}{l}\text { ATC }+16 \\
\text { meses }\end{array}$ & $\begin{array}{c}\text { ATC } * 24 \\
\text { meses }\end{array}$ \\
\hline
\end{tabular}




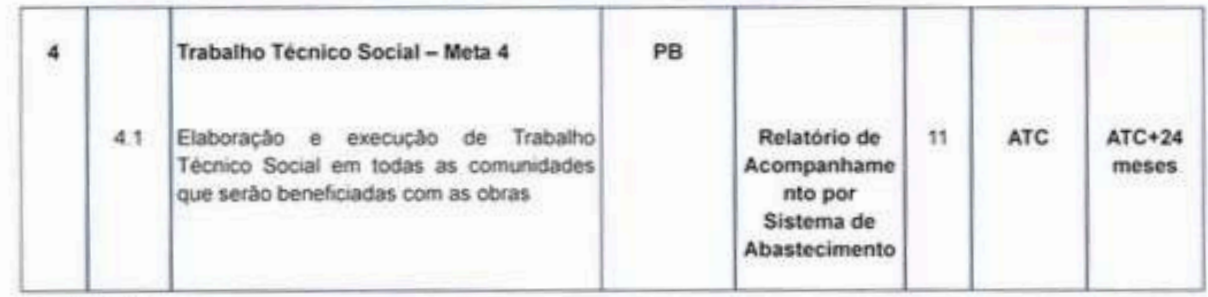

Nota: $A T C=$ Data de Assinatura do Termo de Compromisso

\begin{tabular}{|c|c|c|}
\hline \multirow{2}{*}{$\begin{array}{l}\text { MINISTEREIO DA } \\
\text { INTEGRAÇĀO NACIONAL } \\
\text { SECRETARIA DE } \\
\text { INFRAESTRUTURA HIDRICA }\end{array}$} & \multirow[b]{2}{*}{ PLANO DE TRABALHO } & processo n"59100.000288/2015-21 \\
\hline & & Pagina 4/5 \\
\hline
\end{tabular}

5. CRONOGRAMA DE DESEMBOLSO (RS 1,00 )

VALOR DAS PARCELAS

Concedente/Proponente - MI

\begin{tabular}{|c|c|c|c|c|c|c|c|c|c|}
\hline Funcional Programática & $\begin{array}{c}\text { Meta/Natureza } \\
\text { da Despesa }\end{array}$ & $1^{\circ}$ Mès & $\begin{array}{c}2^{\circ} \\
\text { Mes }\end{array}$ & $\begin{array}{l}3^{\circ} \\
\text { Mes }\end{array}$ & $4^{\circ}$ Mès & $\begin{array}{l}5^{\circ} \\
\text { Mes }\end{array}$ & $\begin{array}{c}6^{6} \\
\text { Més }\end{array}$ & $\begin{array}{c}7^{\circ} \\
\text { Més }\end{array}$ & $\begin{array}{l}8^{e} \\
\text { Més }\end{array}$ \\
\hline 18.544 .2051 .5900 .0020 & 449051 & $3000,000,90$ & & & 1623.05284 & & & & \\
\hline 18.544 .2051 12EP 0020 & 449051 & 2.000000000 & & & $7.551 .454,49$ & & & & \\
\hline TOTAL & & $5.000,000,00$ & & & $9.174507,33$ & & & & \\
\hline
\end{tabular}

\begin{tabular}{|c|c|c|c|c|c|c|c|c|c|}
\hline Funcional Programática & $\begin{array}{c}\text { Meta/Natureza } \\
\text { da Despesa }\end{array}$ & ge Mess & $10^{\circ}$ Mes & $\begin{array}{l}11^{\circ} \\
\text { Mess }\end{array}$ & \begin{tabular}{|c|}
$12^{\prime \prime}$ \\
Mes
\end{tabular} & $\begin{array}{l}13^{\circ} \\
\text { Mes }\end{array}$ & $\begin{array}{l}14^{\circ} \\
\text { Mes }\end{array}$ & $\begin{array}{l}15^{\circ} \\
\text { Mes }\end{array}$ & $\begin{array}{l}16^{\circ} \\
\text { Mès }\end{array}$ \\
\hline 18.544 .2051 .5900 .0020 & 449051 & & 1.588 .820 .96 & & & & & & \\
\hline $185442051.12 E P$ OO20 & 449051 & & 8.934259 .78 & & & & & & \\
\hline TOTAL & & & 10523000,74 & & & & & & \\
\hline
\end{tabular}

\begin{tabular}{|c|c|c|c|c|c|c|c|c|c|}
\hline Funcional Programatica & $\begin{array}{c}\text { Meta/Natureza } \\
\text { da Despesa }\end{array}$ & $\begin{array}{l}17^{\circ} \\
\text { Mès }\end{array}$ & $18^{\circ}$ Més & $\begin{array}{c}19^{\circ} \\
\text { Mes }\end{array}$ & $\begin{array}{l}20^{\circ} \\
\text { Mess }\end{array}$ & $\begin{array}{l}21^{*} \\
\text { Mess }\end{array}$ & $22^{\circ}$ Mès & $\begin{array}{l}23^{\circ} \\
\text { Mes }\end{array}$ & $\begin{array}{l}24^{\circ} \\
\text { Mês }\end{array}$ \\
\hline 18.544 .2051 .5900 .0020 & & & $3.944 .697 / 49$ & & & & $2000,000,00$ & & \\
\hline $18.544 .2051 .12 E P .0020$ & & & $3.077 .350,80$ & & & & $2,000,000,00$ & & \\
\hline TOTAL & & & $7.022 .048,29$ & & & & $4.000,000,00$ & & \\
\hline
\end{tabular}




\begin{tabular}{|c|l|l|}
\hline MINISTÉRIO DA & processo $n^{\natural 5} 59100.00028812015-21$ \\
\cline { 3 - 3 } $\begin{array}{c}\text { INTEGRACAON NACIONAL } \\
\text { SECRETARIA DE } \\
\text { INFRAESTRUTURA HIDRICA }\end{array}$ & PLANO DE TRABALHO & Página $5 / 5$ \\
\hline
\end{tabular}

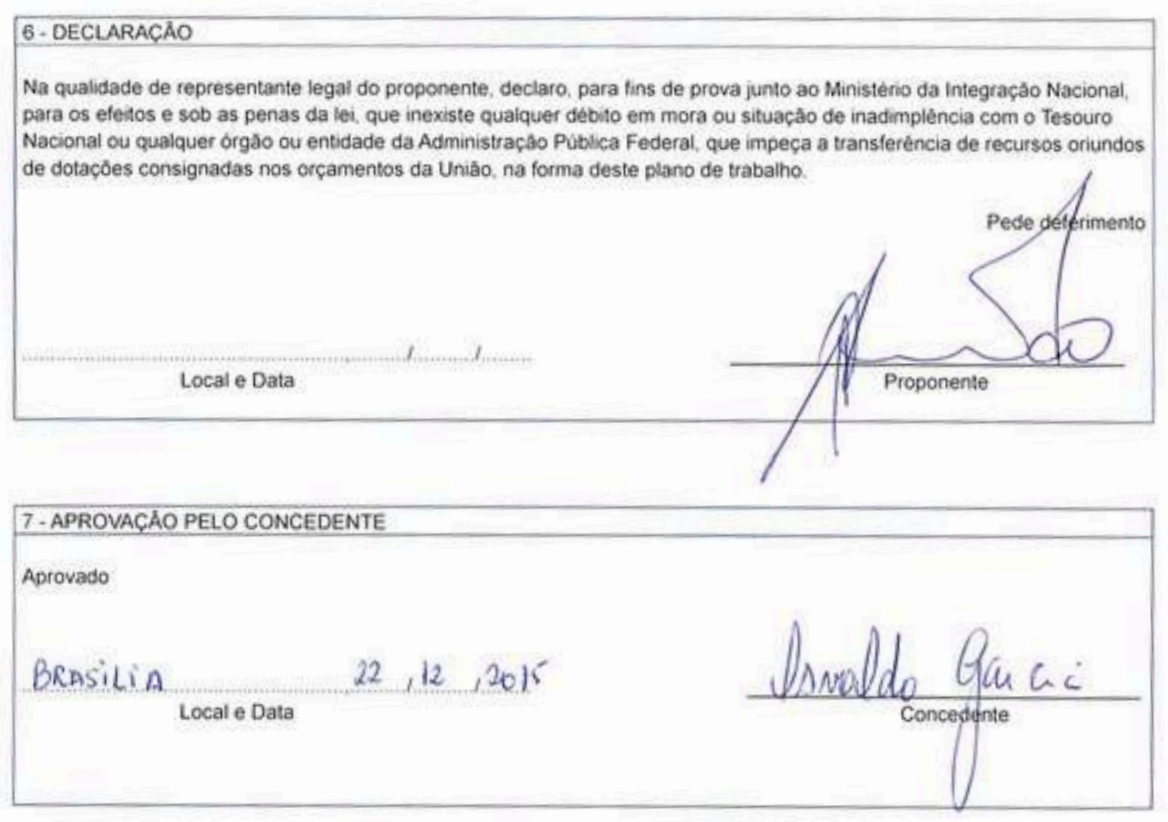

ANEXO I

\begin{tabular}{|c|c|c|c|c|c|c|c|}
\hline \multirow{2}{*}{ Municipio } & \multirow{2}{*}{ Estado } & \multirow{2}{*}{ Comunidades } & \multirow{2}{*}{\begin{tabular}{|l|} 
População \\
2013 (hab)
\end{tabular}} & \multicolumn{2}{|c|}{ Coordenadas } & \multirow{2}{*}{ Sistema } & \multirow{2}{*}{$\begin{array}{l}\text { Orcamento } \\
\text { Estimado }\end{array}$} \\
\hline & & & & $\mathrm{N}(\mathrm{m})$ & $E(m)$ & & \\
\hline Monteiro & PB & $\begin{array}{l}\text { Espinito } \\
\text { Santo }\end{array}$ & 68 & 9.121 .447 & 698.633 & \multirow{3}{*}{ Passagem_de_Pedra } & RS $\quad 904366,47$ \\
\hline Monteiro & PB & Pocinhos & 176 & 9.121 .488 & 695628 & & RS 1004089,15 \\
\hline Monteiro & PE & Cachoeirinh & 216 & 9.121 .119 & 699.811 & & RS $\quad 1.232 .202 .60$ \\
\hline Montexo & PB & Pau ofAreo & 144 & 9.125 .655 & 703.382 & \multirow{4}{*}{ Rigideira } & \multirow{4}{*}{$6410,796,30$} \\
\hline Monteiro & $P B$ & Rigideira & 168 & 9.122 .777 & 702541 & & \\
\hline Monteiro & PB & Bredo 1 & 1.008 & 9.126 .527 & 701.180 & & \\
\hline Monteiro & PB & Mulungu & 1.200 & 9.125459 & 701.781 & & \\
\hline $\begin{array}{c}\text { Monte } \\
\text { Horebe }\end{array}$ & PB & Chapada & $6 B$ & 9.202566 & 542.062 & Chapada & RS $904.366,47$ \\
\hline $\begin{array}{c}\text { Monte } \\
\text { Horebe }\end{array}$ & PB & Serrinha & 80 & 9.204 .726 & 542.272 & Serninha & RS 2.318.347.28 \\
\hline $\begin{array}{c}\text { Monte } \\
\text { Horebe }\end{array}$ & PB & Braga & 1200 & 9.205535 & 541.896 & Braga & RS $1.400 .339,08$ \\
\hline
\end{tabular}


ANEXO II

\begin{tabular}{|c|c|c|c|c|c|c|c|}
\hline \multirow{3}{*}{ Municipio } & \multirow{3}{*}{ Estado } & \multirow{3}{*}{ Comunidades } & \multirow{3}{*}{$\begin{array}{l}\text { ATvEX } \\
\text { Populaçăo } \\
2013 \text { (hab) }\end{array}$} & \multirow{2}{*}{\multicolumn{2}{|c|}{ Coordenadas }} & \multirow{3}{*}{ Sistema } & \\
\hline & & & & & & & \multirow{2}{*}{$\begin{array}{l}\text { Orçamento } \\
\text { Estimado }\end{array}$} \\
\hline & & & & $N(m)$ & $E(m)$ & & \\
\hline Monteiro & PB & Tingui II & 172 & 9.128 .593 & 702.481 & \multirow{3}{*}{ Bom Jesus } & \multirow{3}{*}{$\frac{\text { RS }}{3.500 .512,17}$} \\
\hline Monteiro & $\mathrm{PB}$ & Tinguil I & 532 & 9.128 .752 & 703.984 & & \\
\hline Monteiro & PB & Bom Jesus & 672 & 9.132447 & 703.386 & & \\
\hline Monteiro & PB & $\begin{array}{l}\text { Serrote de } \\
\text { Baxo }\end{array}$ & 148 & 9.123 .689 & 709.527 & \multirow{6}{*}{$\begin{array}{l}\text { Sitio do } \\
\text { Meio }\end{array}$} & \multirow{6}{*}{$\begin{array}{c}\text { RS } \\
5.433 .747,60\end{array}$} \\
\hline Monteiro & PB & Serrote & 160 & 9.121 .511 & 70.796 & & \\
\hline Monteiro & PB & $\begin{array}{l}\text { Serrote de } \\
\text { Cima }\end{array}$ & 208 & 9.122 .210 & 708.085 & & \\
\hline Monteiro & PB & Garapa & 352 & 9.122 .673 & 709.094 & & \\
\hline Monteiro & PB & Tamanduâ & 600 & 9.125 .102 & 711.349 & & \\
\hline Monteiro & PB & Sitio do Meio & 668 & 9.132 .003 & 711.560 & & \\
\hline $\begin{array}{l}\text { Cachoeira } \\
\text { dos Indios }\end{array}$ & PB & Garguelo & 420 & 9223.060 & 537.345 & \multirow{2}{*}{ Garguelo } & \multirow{2}{*}{$\begin{array}{c}\text { RS } \\
1.588 .820 .96\end{array}$} \\
\hline $\begin{array}{l}\text { Săo J de } \\
\text { Piranhas }\end{array}$ & PB & Antas II & 108 & 9.219 .632 & 541.398 & & \\
\hline
\end{tabular}

ANEXO III

\begin{tabular}{|c|c|c|c|c|c|c|c|}
\hline \multirow{2}{*}{ Municipio } & \multirow{2}{*}{ Estado } & \multirow{2}{*}{ Comunidades } & \multirow{2}{*}{$\begin{array}{l}\text { Populaçāo } \\
2013 \text { (hab) }\end{array}$} & \multicolumn{2}{|c|}{ Coordenadas } & \multirow{2}{*}{ Sistema } & \multirow{2}{*}{$\begin{array}{c}\text { Orçamento } \\
\text { Estimado }\end{array}$} \\
\hline & & & & $N(m)$ & $E(m)$ & & \\
\hline Monteiro & PB & Pau Ferro & 500 & 9.129 .695 & 717.595 & \multirow{3}{*}{ Santana } & \multirow{3}{*}{$\begin{array}{c}\text { RS } \\
5.077 .350 .78\end{array}$} \\
\hline Monteiro & PB & Santana II & 612 & 9.129 .469 & 715.005 & & \\
\hline Monteiro & PB & Santana I & 884 & 9.128 .133 & 715.671 & & \\
\hline $\begin{array}{l}\text { Sajo 3. de } \\
\text { Piranhas }\end{array}$ & PB & Benedita & 20 & 9.216 .760 & 547,417 & \multirow{4}{*}{ Serra do vital } & \multirow{4}{*}{$\begin{array}{c}\text { RS } \\
1.167 .192,10\end{array}$} \\
\hline $\begin{array}{l}\text { Săo 1. de } \\
\text { Piranhas }\end{array}$ & PB & Catingueira & 8 & 9.218 .311 & 546.996 & & \\
\hline $\begin{array}{l}\text { São J. de } \\
\text { Piranhas }\end{array}$ & PB & $\begin{array}{l}\text { Serra do } \\
\text { Vital } \\
\end{array}$ & 200 & 9.220 .650 & 546.136 & & \\
\hline $\begin{array}{l}\text { São J. de } \\
\text { Piranhas }\end{array}$ & PB & $\begin{array}{l}\text { Serrote das } \\
\text { Flores }\end{array}$ & 160 & 9.216 .993 & $\$ 45.978$ & & \\
\hline Cajazeiras & PB & Arruido & 520 & 9.222 .731 & 544.982 & \multirow{4}{*}{ Astuido } & \multirow{4}{*}{$\frac{\text { RS }}{4.777505 .40}$} \\
\hline Cajazeiras & PB & $\begin{array}{c}\text { Terra } \\
\text { Molhada } \\
\end{array}$ & 336 & 9.225 .455 & 547.473 & & \\
\hline Cajazeiras & PB & Caiçara II & 208 & 9.223 .824 & 545.073 & & \\
\hline Cajazeiras & PB & Caiçara 1 & 408 & 9.222 .848 & 546.878 & & \\
\hline
\end{tabular}

